\title{
HYDROLOGY OF AREA 18, EASTERN COAL PROVINCE, TENNESSEE,
}

REVDEW DRRAP

- CUMBERLAND RIVER

- COLLINS RIVER

- CANEY FORK

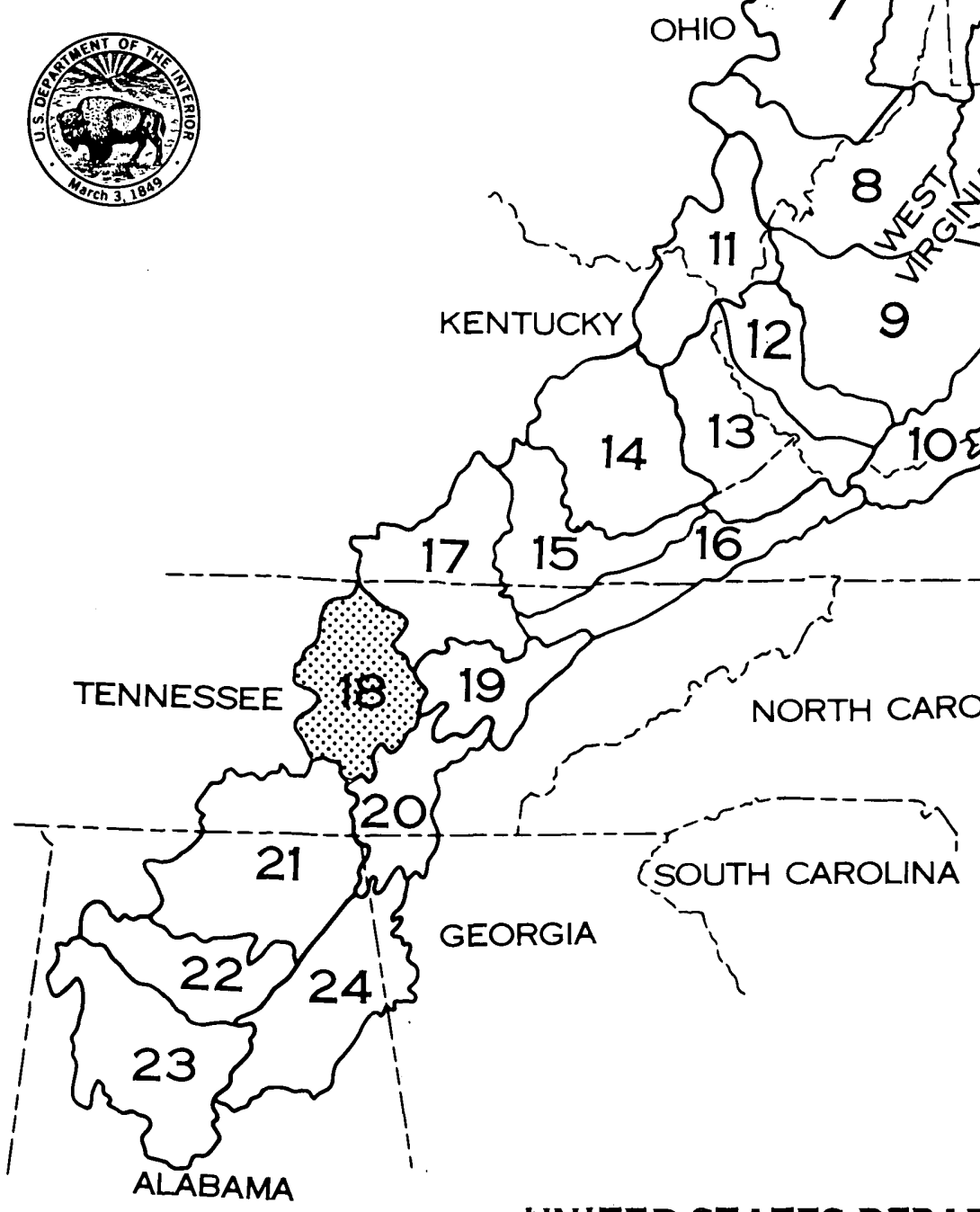

CARTOGRAPHIC SECTION

WISCONSIN DISTRICT

UNITED STATES DEPARTMENT OF THE INTERIOR GEOLOGICAL SURVEY 


\section{HYDROLOGY OF AREA 18, EASTERN COAL PROVINCE, TENNESSEE}

BY

V. JEFF MAY AND OTHERS

U.S. GEOLOGICAL SURVEY

WATER-RESOURCES INVESTIGATIONS 8 1-492

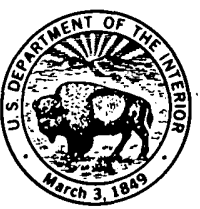

NASHVILLE, TENNESSEE

AUGUST, 1981 


\title{
UNITED STATES DEPARTMENT OF THE INTERIOR
}

JAMES G. WATT, SECRETARY

\section{GEOLOGICAL SURVEY}

\author{
Doyle G. Frederick, Acting Director
}

For additional information write to:

U.S. Geological Survey A413 Federal Building

U.S. Courthouse

Nashville, TN 37203 


\section{CONTENTS}

Page

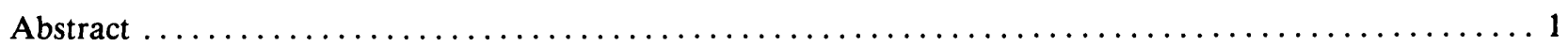

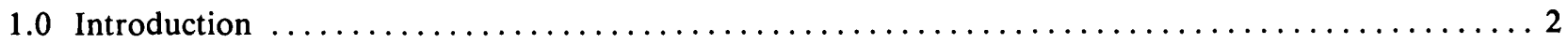

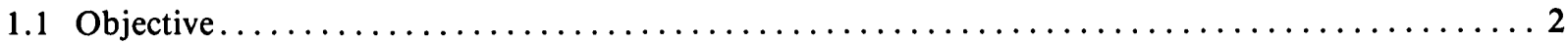

F. A. Kilpatrick and J. R. Rollo

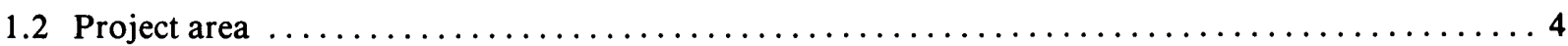
V. Jeff May

1.3 Hydrologic problems related to surface coal mining $\ldots \ldots \ldots \ldots \ldots \ldots \ldots \ldots \ldots \ldots \ldots \ldots \ldots \ldots \ldots \ldots$ V. Jeff May

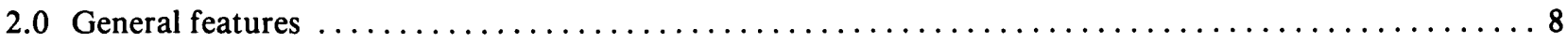

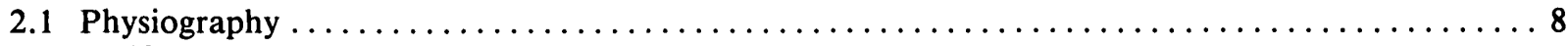

David R. Bauer

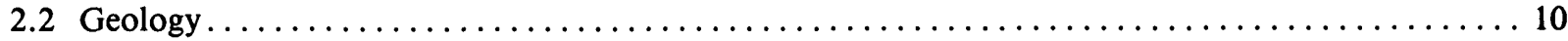

David R. Bauer

2.3 Soils . . . . . . . . . . . . . . . . . . . . . . . . . . . . . . . . . . . . . . . . . . . . . 12

David R. Bauer

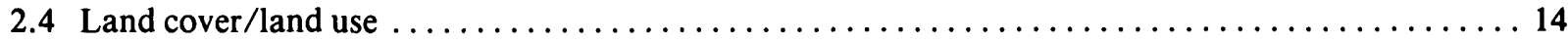

E. F. Hollyday

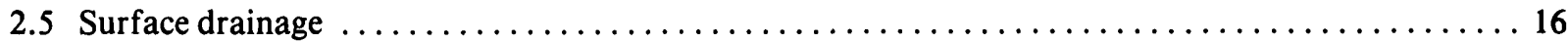

V. Jeff May

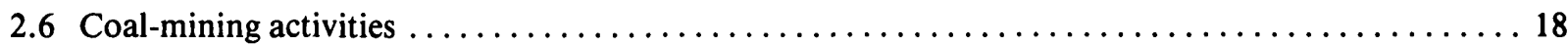
V. Jeff May

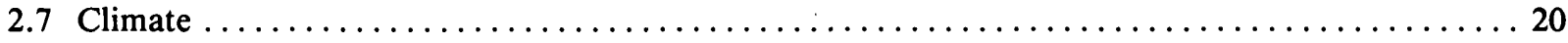

Edward B. Boyd

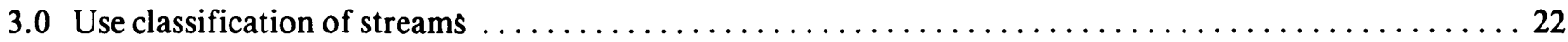

V. Jeff May

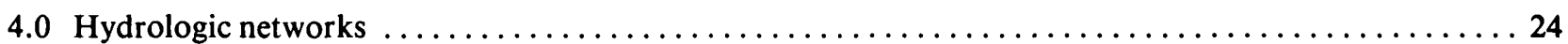

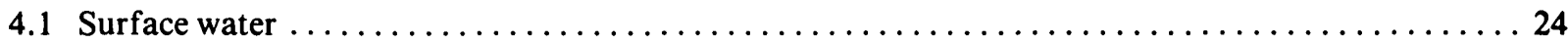

V. Jeff May

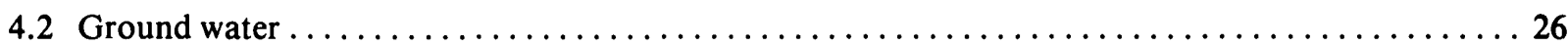
V. Jeff May

5.0 Surface water $\ldots \ldots \ldots \ldots \ldots \ldots \ldots \ldots \ldots \ldots \ldots \ldots \ldots \ldots \ldots \ldots \ldots \ldots \ldots \ldots \ldots \ldots \ldots \ldots \ldots \ldots \ldots \ldots \ldots \ldots \ldots, 28$

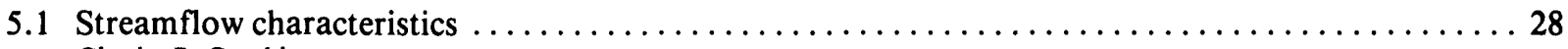

Charles R. Gamble

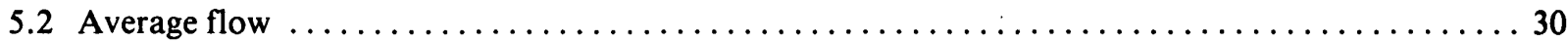

Charles R. Gamble

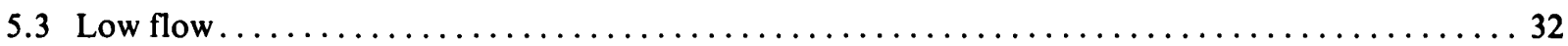

Charles R. Gamble

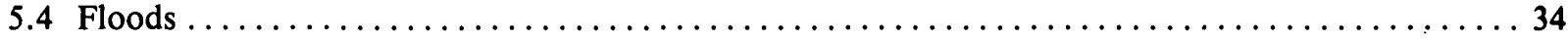




\subsection{Floods--Continued}

5.4.1 Magnitude and seasonal distribution of floods $\ldots \ldots \ldots \ldots \ldots \ldots \ldots \ldots \ldots \ldots \ldots \ldots \ldots$ Charles $R$. Gamble

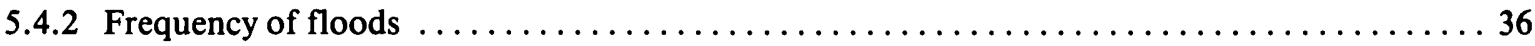
Charles R. Gamble

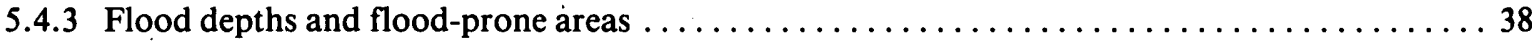
Charles R. Gamble

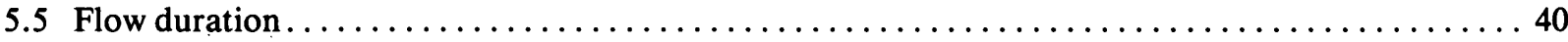
Charles R. Gamble

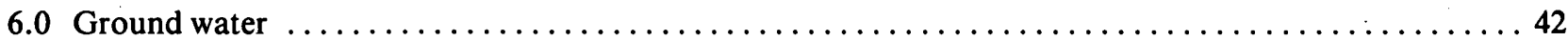

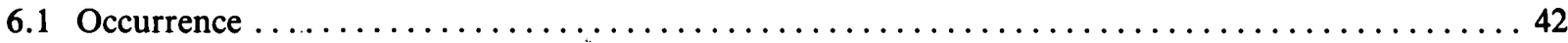

J. V. Brahana

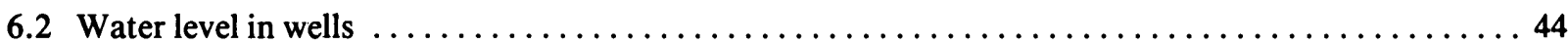
E. F. Hollyday and Jo Ann Macy

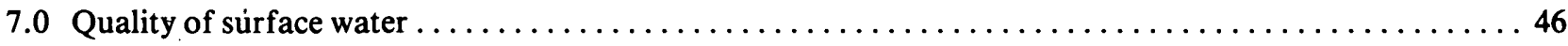

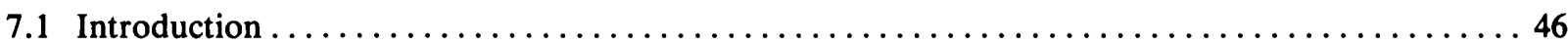
Michael W. Gaydos

7.2 Specific conductance and dissolved solids $\ldots \ldots \ldots \ldots \ldots \ldots \ldots \ldots \ldots \ldots \ldots \ldots \ldots \ldots$ Michael W. Gaydos

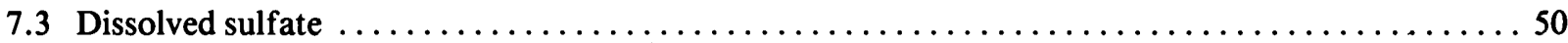
Michael W. Gaydos

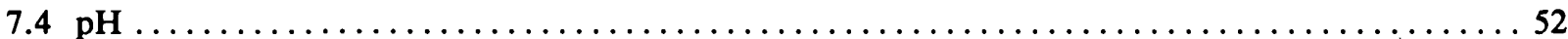
Michael W. Gaydos

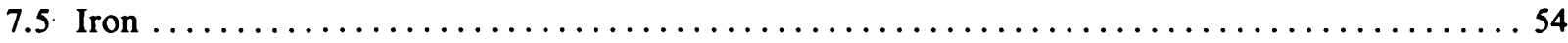
Michael W. Gaydos

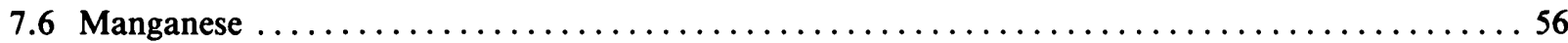
Michael $W$. Gaydos

7.7 Trace constituents . . . . . . . . . . . . . . . . . . . . . . . . . . . . . . . . . . . . 58 Michael W. Gaydos

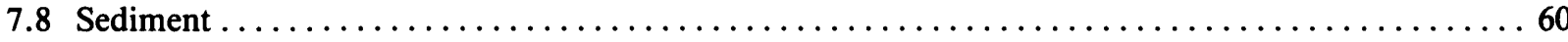
William P. Carey

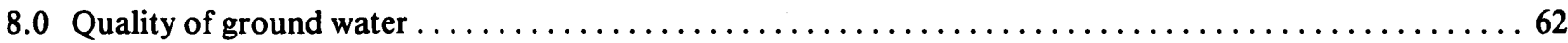
Michael $W$. Gaydos

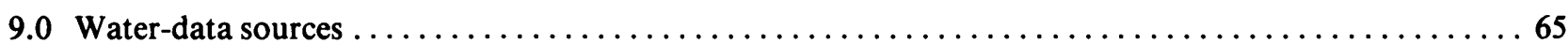

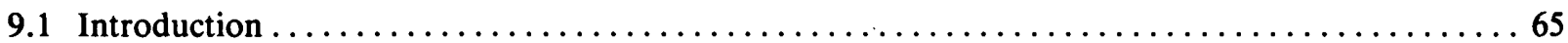

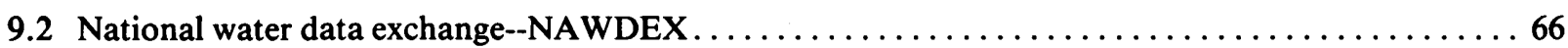

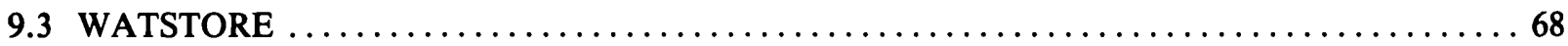

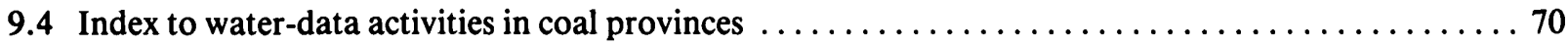

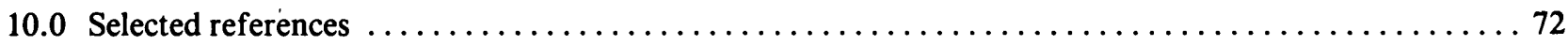

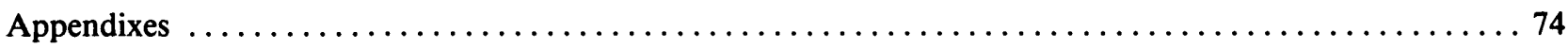

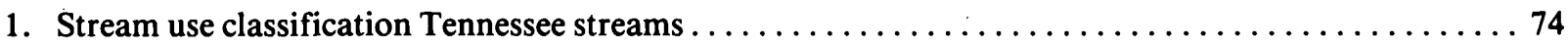

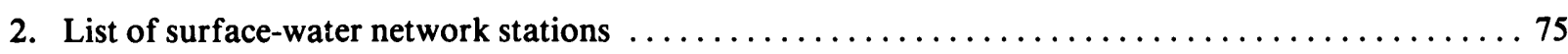

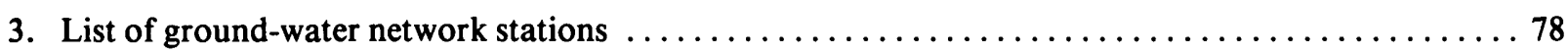




\section{FACTORS FOR CONVERTING INCH-POUND UNITS TO INTERNATIONAL SYSTEM OF UNITS (SI)}

For the convenience of readers who may want to use International System of Units (SI), the data may be converted by using the following factors:

Multiply inch-pound units

inches (in)

inches per hour (in/h)

feet $(\mathrm{ft})$

feet per mile ( $\mathrm{ft} / \mathrm{mi})$

miles (mi)

square miles $\left(\mathrm{mi}^{2}\right)$

gallons per minute (gal/min)

million gallons per day (mgal/d)

cubic feet per second $\left(\mathrm{ft}^{3} / \mathrm{s}\right)$

cubic feet per second per square mile $\left[\left(\mathrm{ft}^{3} / \mathrm{s}\right) / \mathrm{mi}^{2}\right]$

tons per square mile per year $\left[\left(\right.\right.$ tons $\left.\left./ \mathrm{mi}^{2}\right) / \mathrm{yr}\right]$
By

To obtain SI units

25.4

25.4

2.54

0.3048

0.1894

1.609

2.590

0.06309

0.04381

3,785

0.02832

0.01093

0.03753 millimeters (mm)

millimeters per hour $(\mathrm{mm} / \mathrm{h})$ centimeters per hour $(\mathrm{cm} / \mathrm{h})$

meters (m)

meters per kilometer $(\mathrm{m} / \mathrm{km})$

kilometers (km)

square kilometers $\left(\mathrm{km}^{2}\right)$,

liters per second $(\mathrm{L} / \mathrm{s})$

cubic meters per second $\left(\mathrm{m}^{3} / \mathrm{s}\right)$ cubic meters per day $\left(\mathrm{m}^{3} / \mathrm{d}\right)$

cubic meters per second $\left(\mathrm{m}^{3} / \mathrm{s}\right)$

cubic meters per second per square kilometer $\left[\left(\mathrm{m}^{3} / \mathrm{s}\right) / \mathrm{km}^{2}\right]$

metric tons per square kilometer per year $\left[\left(\mathrm{t} / \mathrm{km}^{2}\right) / \mathrm{a}\right]$ 


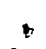

$\nabla$

i

$\gamma$

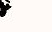

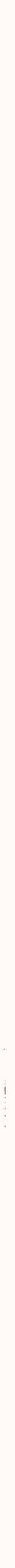

$q^{T}$

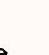




\section{ABSTRACT}

The Eastern Coal province is divided into 24 separate hydrologic reporting areas. The division is ing activity. Hydrologic units (drainage basins) or parts of basins are combined to form each area. Area 18 is located near the southern end of the Eastern Coal province, in the Cumberland River basin, and covers 3,380 square miles.

Each report is designed to be useful to mine ownrs and operators and consulting engineers by preins and identification of sources of hydrologic information. The report format consists of brief text and supporing illustrations or tables on a series of hydrologic topics whic

Area 18 is divided into three physiographic regions. These regions extend across the area in nerthwest, the Cumberland Plateau, Highland Rim and Central Basin. The Cumberland Plateau an Central Basin each comprise about one-fourth of

Altitudes decrease from east to west from abou 2,000 feet at the eastern edge of the area to about 600 feet at the western edge. Most of the change in altitude occurs at the western edge of the Cumberland are common.

The Cumberland Plateau is underlain by coalbearing sandstone and shale of Pennsylvanian age. The Highland Rim and Central Basin are underlain by carbonates of Ordovician and Mississippian age. and shale that form the Cumberand Plateu. rocks are relatively flat-lying and have no significan disconformities. The main coal beds underneath the Cumberland Plateau in Area 18 are the Richland and Sewanee seams.

The area is drained by the Cumberland River and tributaries. The Caney Fork, the largest tributary, course draining segments of all geologic formations. Other major streams, all of which drain coal-bearing rocks and are tributary to the Caney Fork, are the Collins River, Rocky River, Calfkiller River, and
Specific conductance of surface water has little variability. Only one sample exceeded 300 micromwere Three of five samples with higher concentration were from Clifty Creek. Acid coal mine drainage is not a serious widespread problem in the large streams. The range in $\mathrm{pH}$ at sites sampled was from 6.3 to 8.2 units except on Clifty Creek where the (heepand Bottom materials in stream channels were analyzed for trace elements, including arsenic, cadmium, chromium, cobalt, copper, lead, mercury, selenium, and zinc. No concentrations were high enough to present water quality problems. Analysis for a simfrom the Collins River in solution for water samples frandace Cor recommended criteria for public water supply. Iron and manganese concentrations, although generally less than mandatory limits, exceed- ed expected natural levels in most streams drainin coal areas. Suspended sediment concentrations oc 14 to 831 milligrams rates ranged from 0.07 to 1,120 tons per day. The suspended sediment consisted mostly of silt- and clay-size particles.

Although ground-water quality in the area is not well known, no widespread problems are apparent. could be troublesome. High concentrations of manganese occur and high chloride and iron concentrations have been reported. However, in most areas, concentrations of iron and manganese are within water-supply criteria. Excessive fluoride concentra-
Neither annual runoff (about 22 inches) nor annual evapotranspiration (about 30 inches) varies significantly throughout Area 18 . There is, however, an charges.

Minimum flows, especially during the drier months of late summer and early fall, are lower on a streams draining the Cumberland Plateau than the are for streams draining other parts of the area. Also, streams on the Plateau do not sustain flows durstreams on the Cumberland Plateau go dry during extended drought conditions; such as a drought that occurs once in 20 years, on an average.

Most floods occur during the winter and spring months. About 65 percent of the annual peaks for occur during the period January through March. In smaller basins, about 25 percent of annual peaks occur in March with the remainder fairly evenly distributed over the rest of the year. Peak flows for given recurrence intervals for comparable basins in crease from east to west across Area 18. This areal variability in peak flows is caused by physiographic three hydrologic areas for flood computations and an equation based on drainage basin size for each area is presented.

Ground water in Area 18 occurs in fractures and cadding planes in sandstone and shale capping the openings in the underlying carbonate in the Highlon Rim, and in shallow solution openings in the limestone in the Central Basin. The depth to water in wells averages about 40 feet but varies tens of feet from place to place with topography and aquife properties while varying several feet within a singl water storage. 


\title{
1.0 INTRODUCTION \\ 1.1 Objective
}

\section{AREA 18 REPORT SUBMITTED IN SUPPORT OF PUBLIC LA W 95-87}

\author{
Existing hydrologic conditions and identification of \\ sources of hydrologic information are presented.
}

This report provides broad hydrologic information, using a brief text with an accompanying map, chart, graph, or other illustrations for each of a series of water-resources related topics. The summation of the topical discussions provides a description of the hydrology of the area. The information contained herein should be useful to surface mine owners and operators, and consulting engineers in the preparation of permits and to regulatory authorities in appraising the adequacy of permit applications.

A need for hydrologic information and analysis on a scale never before required nationally was initiated when the "Surface Mining Control and Reclamation Act of 1977" was signed into law as Public Law 95-87, August 3, 1977. In recognizing the potentially adverse impact that coal mining may have on water resources, Public Law 95-87 requires (1) that each mining-permit applicant make an analysis of the potential effects of the proposed mine on the hydrology of the mine site and adjacent area, (2) that "an appropriate Federal or State agency" provide to each mining-permit applicant "hydrologic information on the general area prior to mining," and (3) that measures be taken by mining permittees to control adverse effects of mining on the "hydrologic balance" and reclamation of the land.

This report broadly characterizes the hydrology of Area 18 in Tennessee as delineated in figures 1.1-1 and 1.1-2. The hydrologic information presented or available through sources identified in this report, may be used in describing the hydrology of the "general area" of any proposed mine. Furthermore, it is expected that this hydrologic information will be supplemented by the lease applicant's specific site data as well as data from other sources to provide a more detailed picture of the hydrology of the area in the vicinity of the mine and the anticipated hydrologic consequences of the mining operation. 


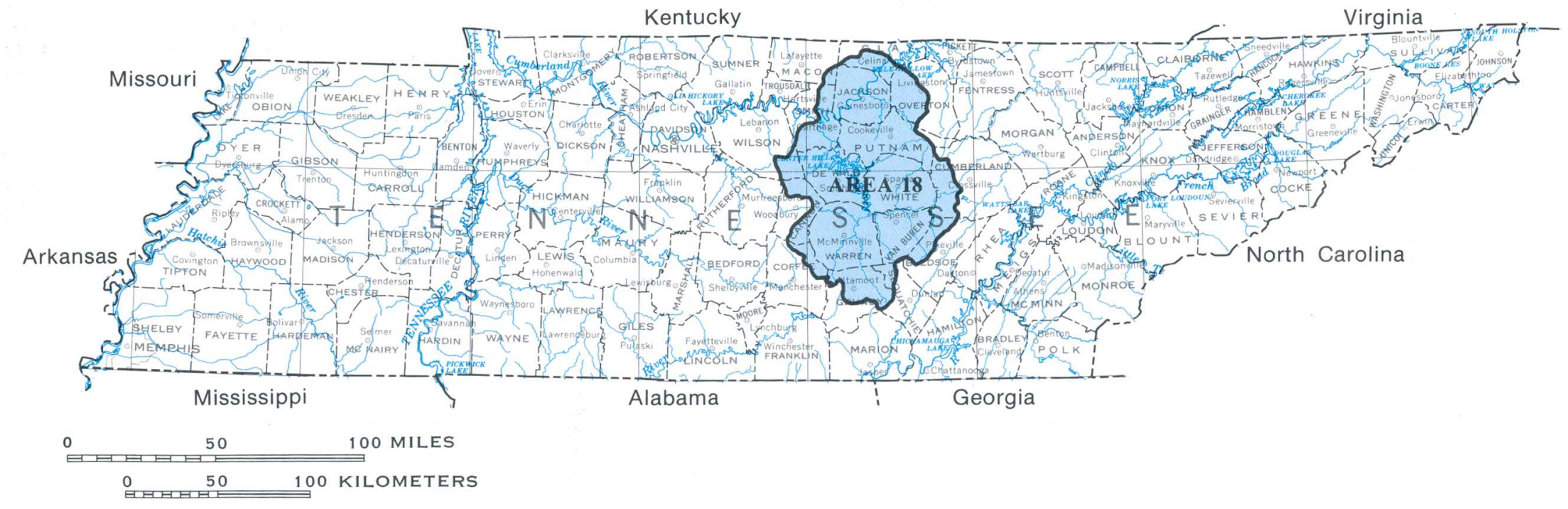

Figure 1.1-1 Location of Area 18

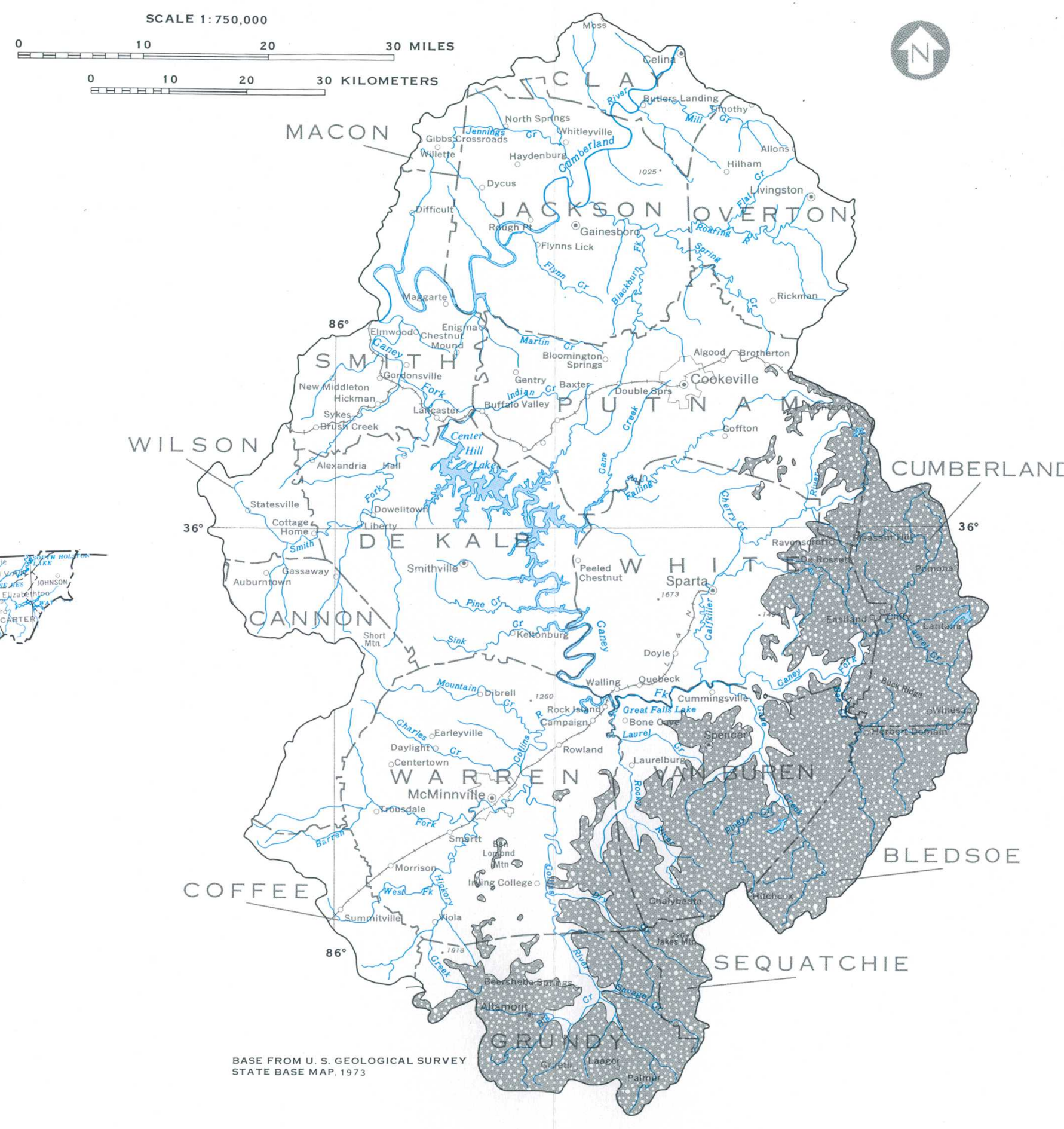

EXPLANATION

Coal resources area 


\title{
1.0 INTRODUCTION(Continued) \\ 1.2 Project Area
}

\section{AREA 18 LOCATED IN SOUTHERN PART OF EASTERN COAL PROVINCE}

\author{
Area 18 includes 3,380 square miles in the \\ Cumberland River basin in central Tennessee.
}

The Eastern Coal province is divided into 24 hydrologic reporting areas. The division is based on hydrologic factors, location, size, and mining activity. Hydrologic units (drainage basins) or parts of units are combined to form each area (fig. 1.2-1).

Area 18 is located in central Tennessee and covers all of Jackson, De Kalb, White, Warren, and Van Buren counties, and parts of 12 surrounding counties (fig. 1.2-1). It lies near the southern end of the Eastern Coal province which extends from Pennsylvania to Alabama covering parts of nine states.

Coal-bearing rocks in Area 18 underlie the Cumberland Plateau physiographic region (fig. 1.2-2). These rocks form a northeast trending belt along the southeastern border covering about one-fourth of the area. Area 18 includes parts of two other physiographic regions, the Highland Rim and the Central Basin.

The surface drainage, $3,380 \mathrm{mi}^{2}$, is within the Cumberland River basin. Most of the major streams have headwater tributaries that drain the coal-bearing rocks in Area 18 underlying the Cumberland Plateau. Only the Cumberland River flows through Area 18. All other streams originate and end within the area (fig. 1.2-2). The Cumberland River flows into the Ohio River, and the water eventually reaches the Gulf of Mexico by way of the Mississippi River. 


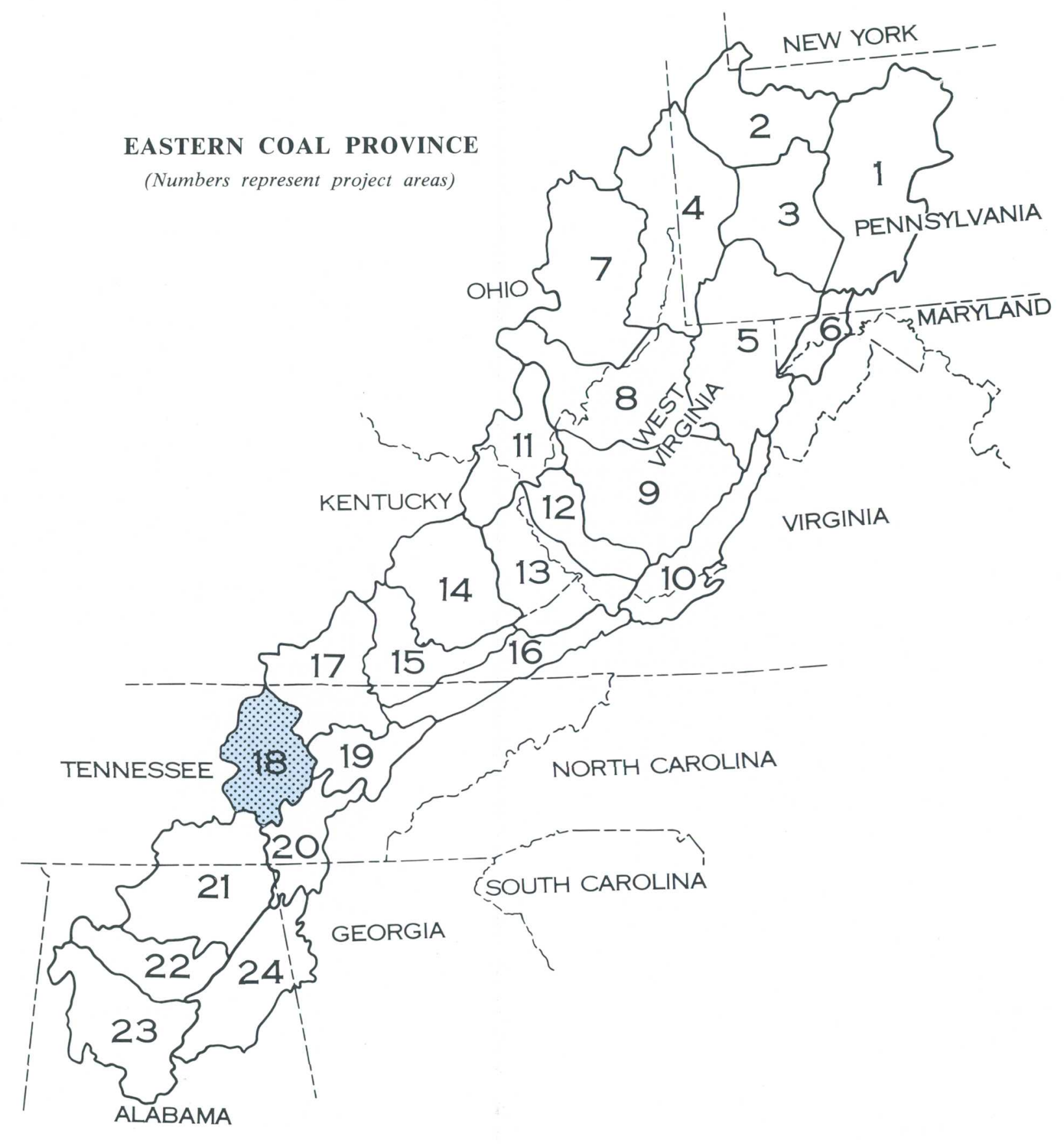

Figure 1.2-1 Location of Area 18 in Eastern Coal Province

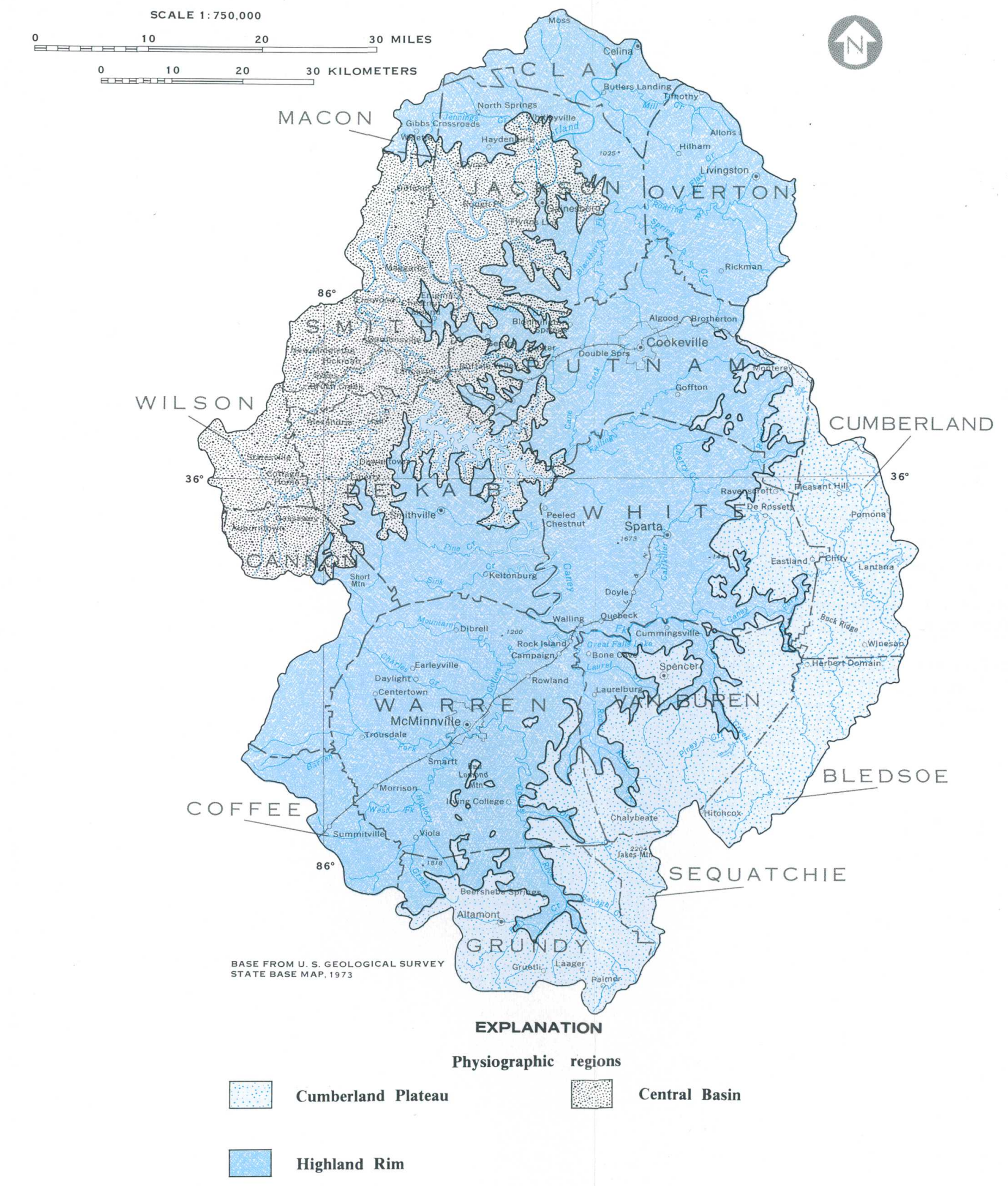

Figure 1.2-2 Physiographic regions

1.0 INTRODUCTION (Continued) 1.2 PROJECT AREA 


\title{
HYDROLOGIC ENVIRONMENT CAN BE ADVERSELY ALTERED BY SURFACE COAL MINING
}

\author{
Erosion, sedimentation, decline in water levels, and degradation of \\ water quality are typical problems associated with surface coal mining.
}

Surface mining drastically alters the environment of undisturbed areas and may cause detrimental changes to the natural environment. Mining activities such as the removal of vegetation, excavation, and dumping of large volumes of unconsolidated spoil materials create unstable areas of loose earth and rock which erode easily and contribute additional sediment to surface streams, channels, and flood plains. If the mined area is reclaimed during mining, or after mining is completed, some of the detrimental environmental effects can be decreased or prevented.

Adverse effects associated with erosion and increased sedimentation include excessive sediment deposition in streams and reservoirs which in turn increases the cost of maintaining navigation channels and treating water for industrial and domestic uses. Other adverse effects include destruction of life habitat, increased flooding due to filling of the stream channels and flood plains by sediment, and reduction of aesthetic value in recreation areas.

Along with increased sedimentation, another common and troublesome water-quality problem is acid-mine drainage. After mining, accelerated weathering of iron bearing minerals (pyrite and marcasite, for example) exposed in spoil materials and coal beds produces sulfuric acid and accelerates the dissolution of minerals. Water draining such a mined area generally has low $\mathrm{pH}$ values (2.5-5.0 units), and increased sulfate and dissolved-solids concentrations. The acidic water reacts with other minerals increasing trace element concentrations such as aluminum, copper, lead, iron, manganese, and zinc. Adverse effects associated with acidic and highly mineralized mine drainage may include reduction of aquatic life, increased corrosiveness of water, limitations on the use of water for domestic and industrial purposes, and reduction of aesthetic value and recreational use.

The adverse effects are most apparent on and near the mine site. The receiving stream for surface and seepage drainage at the mine site usually is most affected. Suspended sediment, mineral content, and $\mathrm{pH}$ will usually diminish in severity downstream from the mine due to settling out of the sediment, and the increased buffering and dilution capacity of the stream.

The decline of ground-water levels can occur in and near surface-mining areas when excavation extends below the water table causing some wells and springs to go dry (fig. 1.3-1). The quality of ground water can also be affected even though the effects may take much longer to detect at points remote from mining activities.

The magnitude of the effects of surface mining on the surrounding hydrologic environment depends on several physical and chemical factors. The more influential factors include mining and reclamation methods, topography, geology, climate, rate of water movement and volumes, the distance to the mine site, and the time elapsed since mining began.

Some chemical and physical relations and trends that can result from surface coal mining are shown in figure 1.3-2. No proportion, ratio, or linearity is implied by these diagrams. 


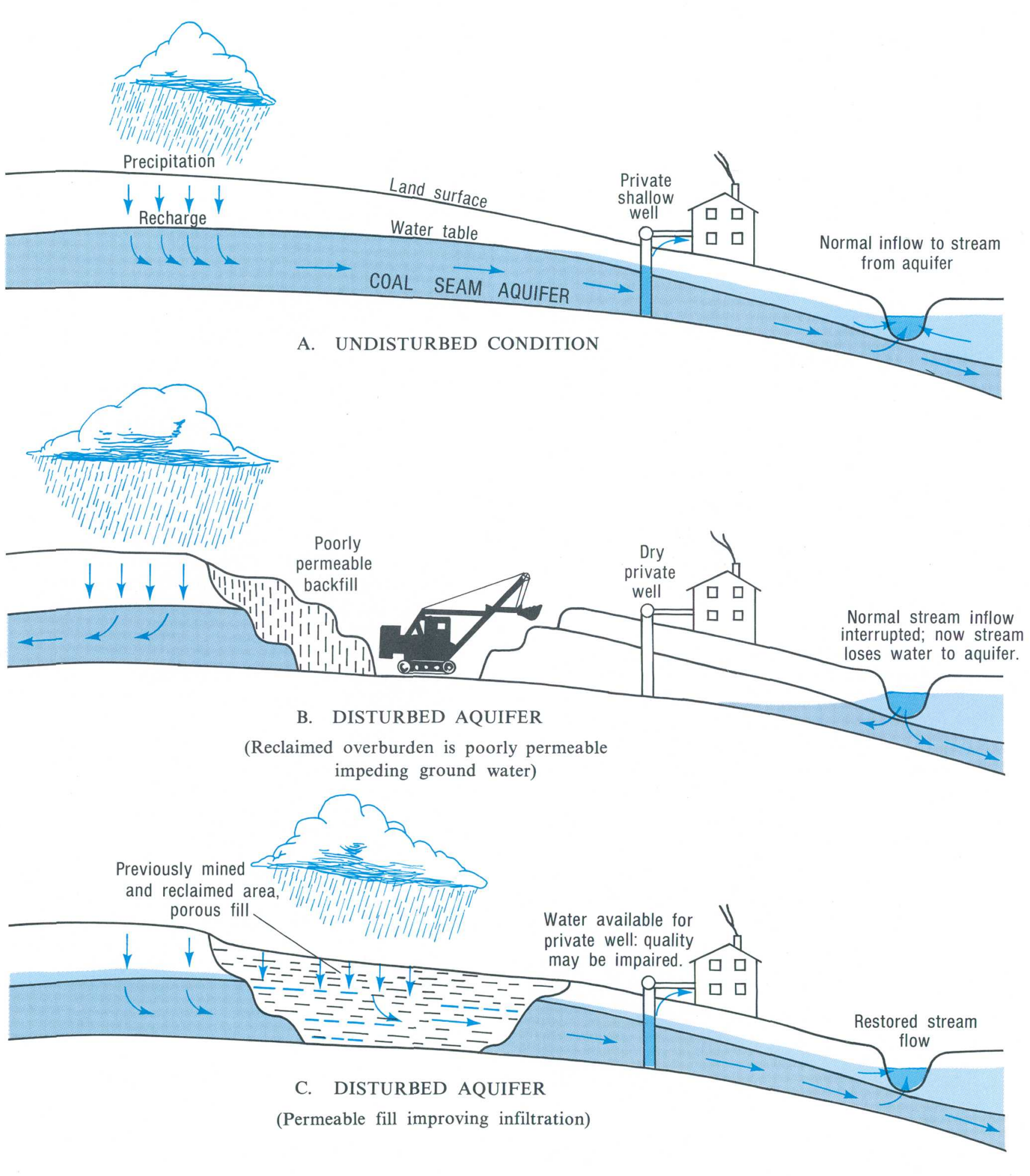

Figure 1.3-1 Possible impacts of mining aquifers
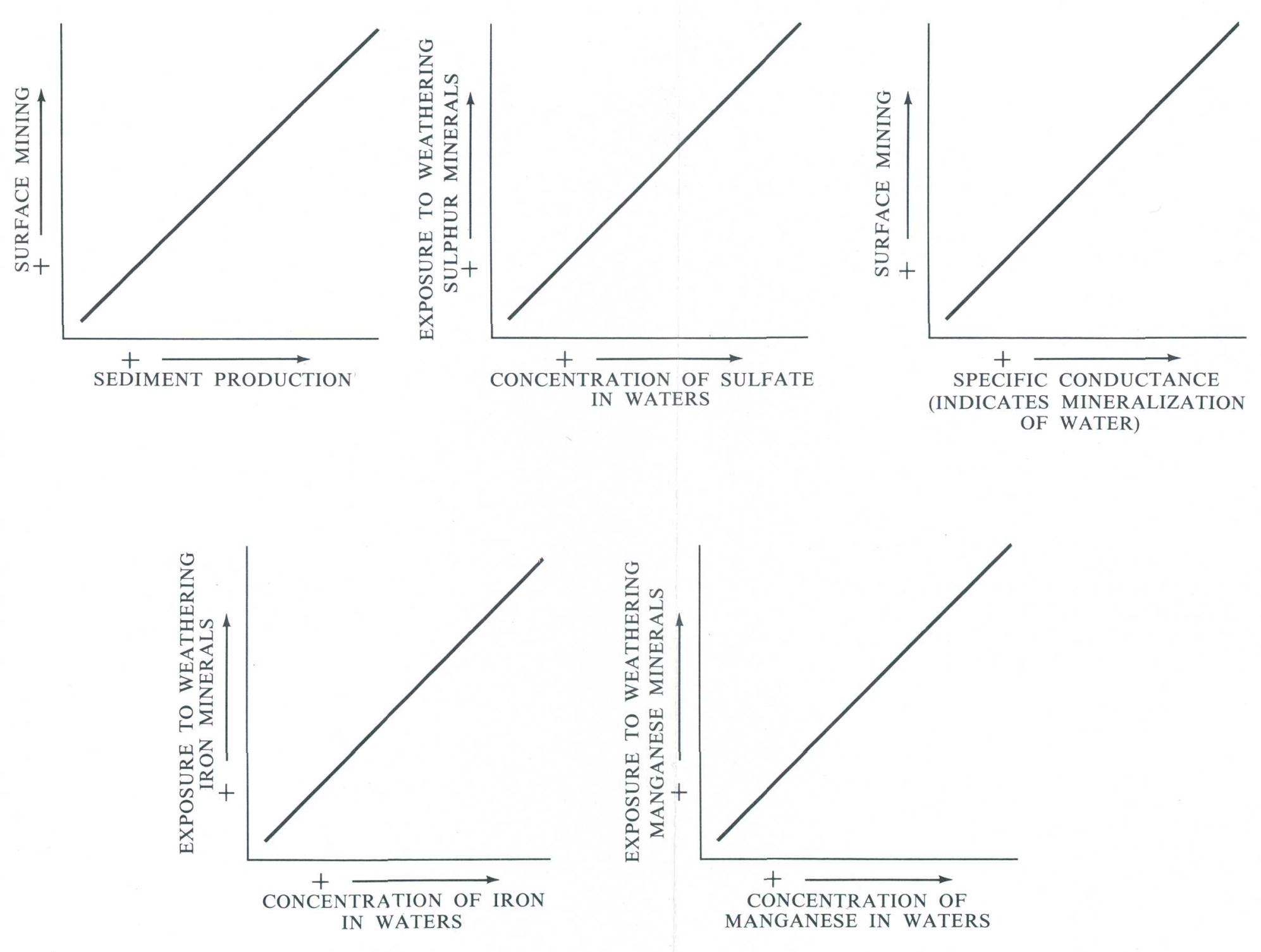

Figure 1.3-2 Example relations and trends that can result from surface coal mining 


\title{
2.0 GENERAL FEATURES \\ 2.1 Physiography
}

\section{THREE PHYSIOGRAPHIC REGIONS REPRESENTED IN AREA 18}

\author{
The three physiographic regions of Area 18 are the Cumberland Plateau \\ which constitutes an upland area, the Highland Rim which forms an \\ intermediate level plain, and the Central Basin which comprises a lowland.
}

The Cumberland Plateau (fig. 2.1-1) occupies $802 \mathrm{mi}^{2}$ in the southeastern part of Area 18 and has an altitude of about $1,800-2,000$ feet. It is drained to the north and west by the Caney Fork and the Calfkiller River. Slopes averaging 2 to 10 percent are common in the gently rolling upland.

The Cumberland Plateau is separated from the Highland Rim by a dissected escarpment with 800-1,000 feet of relief (fig. 2.1-2). This escarpment is called the Cumberland Plateau escarpment. It is made up of steep slopes (60 to 90 percent) with prominent cliffs occuring in the uppermost few hundred feet. Cavernous limestone occurs in the lower two thirds of the escarpment. Where caverns occur, streamflow is diverted underground, causing some major streams to be dry much of the year.

The Highland Rim lies northwest of the Cumberland Plateau escarpment and occupies $1,893 \mathrm{mi}^{2}$ or more than half of Area 18. It averages approximately 1,000 feet in altitude. The near level terrain of the Highland Rim has slopes ranging from 3 to 18 percent.

The Highland Rim is separated from the Central Basin by the Highland Rim escarpment. This escarp- ment has only 300 feet of relief, and it is more dissected than the Cumberland Plateau escarpment. It is characterized by many steep narrow valleys leading westward into the Central Basin lowland.

The Central Basin occupies $685 \mathrm{mi}^{2}$ in the northwestern part of Area 18. The surface is characterized by many knobs or rounded hills that are outliers of the Highland Rim. These knobs rise a few hundred feet above the level of the surrounding lowlands. The lowlands slope gently toward the west from an average altitude of 700 feet at the base of the escarpment to slightly less than 600 feet along the western margin of the area. Slopes ranging from 5 to 30 percent are common in the knob area compared to slopes ranging from 3 to 20 percent in the rolling lowlands.

The two principal streams in Area 18 are the Cumberland River, and Caney Fork. The Caney Fork drains more than half the area and flows through Center Hill Lake while the Cumberland River flows through the Cordell Hull Reservoir. These two rivers join at Carthage on the western margin of Area 18. Other rivers draining the area are the Collins, Falling Water and Roaring Rivers. 


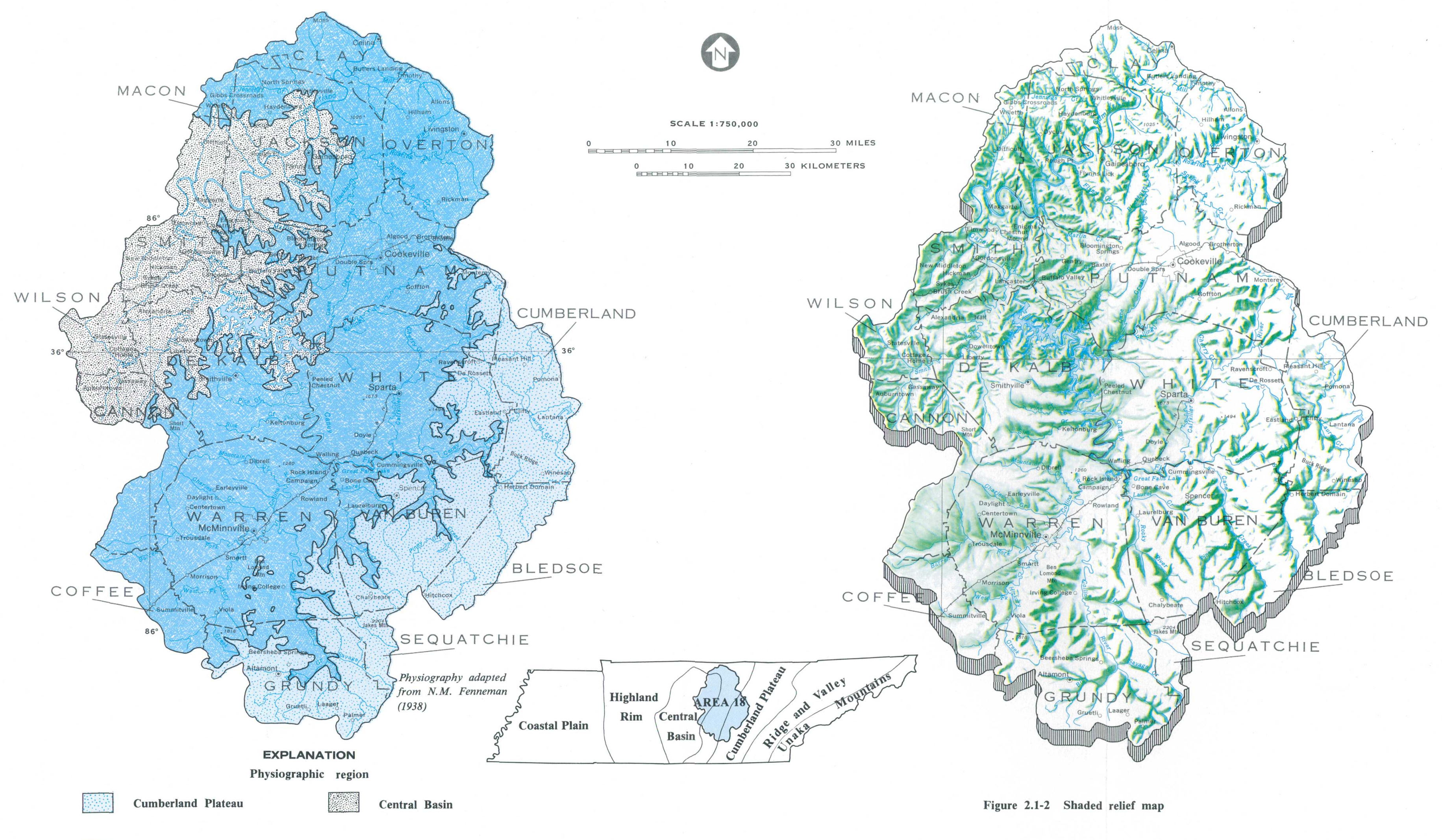

Figure 2.1-1 Physiographic regions 


\title{
2.0 GENERAL FEATURES (Continued) 2.2 Geology
}

\section{DIFFERENT TYPES OF ROCK UNDERLIE EACH OF THE THREE PHYSIOGRAPHIC REGIONS}

\author{
Pennsylvanian sandstones and shales underlie the Cumberland Plateau, \\ Mississippian carbonate rocks underlie the Highland Rim, and \\ Ordovician limestones underlie the Central Basin.
}

The rocks beneath the Cumberland Plateau are of Pennsylvanian age and consist predominately of sandstone, calcareous shale and siltstone with lesser amounts of conglomerate and coal (fig. 2.2-1). These formations cap the Cumberland Plateau with a maximum thickness of about 600 feet. The regolith (soil and decomposed rock overlying bedrock) averages 2 to 3 feet in thickness with anomalous thicknesses up to $\mathbf{3 0}$ feet occurring in fractures and joints. The main coal beds in this area are the Richland and Sewanee seams.

The Pennington Formation of Mississippian age which underlies the Pennsylvanian rocks, grades downward from sandstone and shale to carbonates. It crops out in the upper half of the Cumberland Plateau escarpment and separates the Pennsylvanian rocks above from the Mississippian carbonate rocks below. Mississippian rocks are exposed throughout the entire Highland Rim, underlie the Cumberland Plateau to the east, and cap some of the outlying hills west of the Highland Rim escarpment. Beneath the Cumberland Plateau the Mississippian rocks have a maximum thickness of 1100 feet. Limestone, siltstone, and shale dominate with small amounts of thin-bedded calcareous sandstone. There is an abundance of bedded chert, cherty and dolomitic limestone, and silicastone throughout the Mississippian section as a result of large scale post-depositional replacement of calcium carbonate by silica. The combination of the relatively insoluble silica and the highly soluble surrounding carbonates produces a thick cherty regolith. It averages 30 feet and exceeds 100 feet in thickness in many places on the Highland Rim.

The Chattanooga Shale of Devonian age, underlies the Mississippian rocks and separates them from the Ordovician rocks. It crops out in the upper half of the Highland Rim escarpment where it has an average thickness of 20 feet (fig. 2.2-1).

Ordovician rocks (Nashville and Stones River Groups) crop out in the Central Basin and underlie all of Area 18. The resistant clay-rich phosphatic limestone, dolomite and mudstone of the Nashville Group is underlain by the more soluble limestone of the Stones River Group. These rocks weather to a thin clayey regolith averaging 4 feet in thickness. 


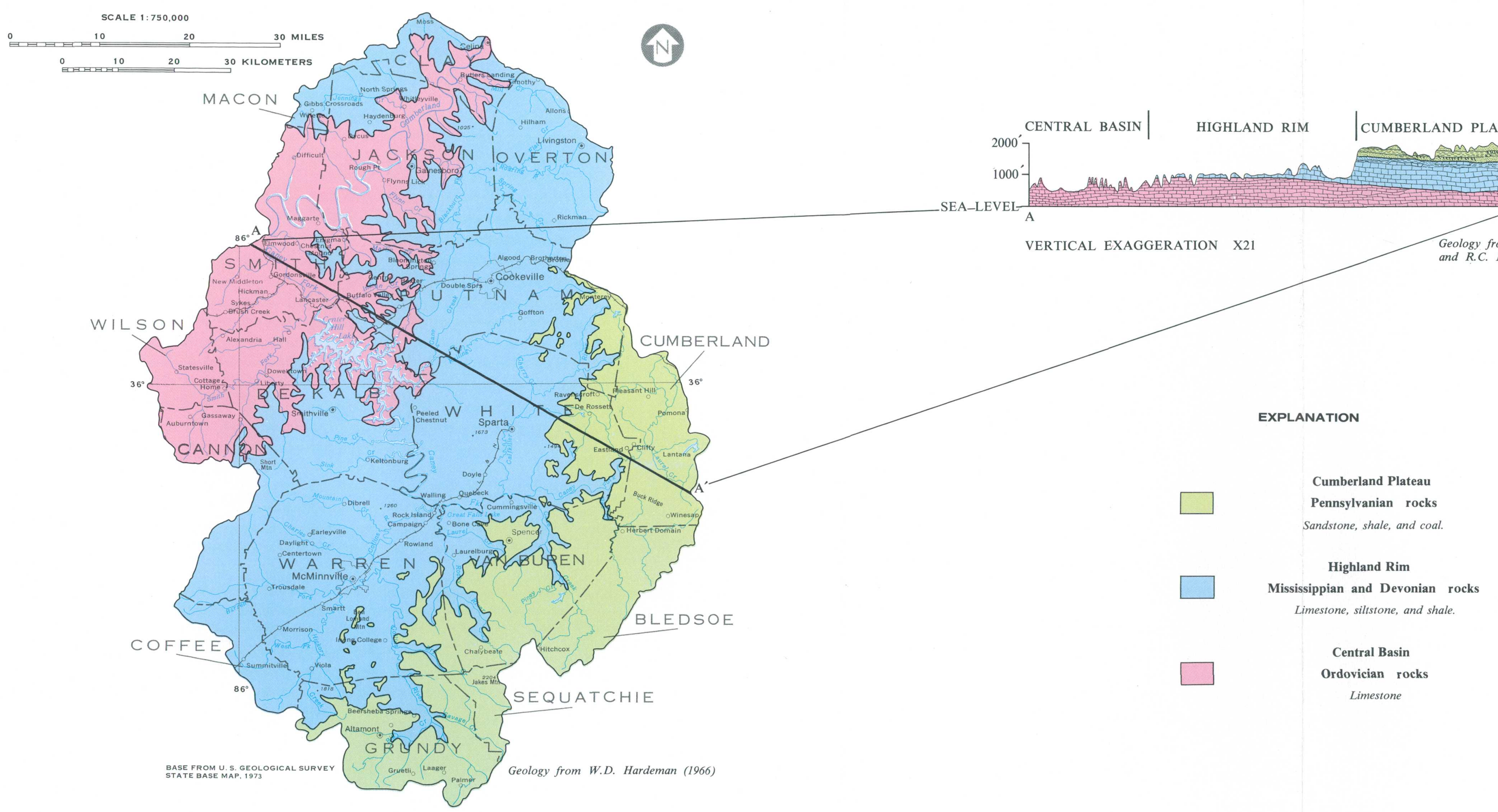




\title{
2.0 GENERAL FEATURES (Continued) \\ 2.3 Soils
}

\section{SOILS HAVE LARGE VARIABILITY IN FERTILITY, SOIL REACTION, PERMEABILITY, WATER CAPACITY, SLOPE, AND EROSION POTENTIAL}

\author{
The soils in Area 18 have a wide range in physical properties \\ depending upon the material from which they were derived, \\ the depth to bedrock, and the land slope. In general, \\ they have low to medium natural fertility, acid soil \\ reaction, slow to moderately rapid rates of permeability, \\ medium to high available water capacity, and moderate \\ to high erosion potential. The physical properties \\ of the soil associations are summarized in the table \\ and the location of the associations are shown \\ on the soil associations map.
}

\begin{abstract}
The soils of the Cumberland Plateau formed in material derived from sandstone, shale and minor amounts of limestone. Depth to bedrock ranges from about 1 to 7 feet, but is mostly 1.5 to 3.5 feet. The soils and slopes are gently rolling to moderately steep. Generally, the soils are low in natural fertility, are strongly acid to very strongly acid, have moderate permeability, and have low to high available water capacity depending on the depth to bedrock. Erosion potential is moderate to high. The stony soils of the upper quarter of the Cumberland Plateau escarpment are derived from the sandstone cliffs and outcrops above. They are dominantly only 1 or 2 feet deep on the very steep slopes in this part of the escarpment. Stony to sandy soils with few to many stones and boulders occur lower on the slope. Here the depth to bedrock is greater, ranging from about 3 feet to 10 feet, permeability is moderately rapid to rapid, and the available water capacity ranges from low to high depending on the depth to bedrock and the amount of stones and boulders in the soil. The soils are only moderately erodible, but the potential for erosion is high because of the steep slopes.
\end{abstract}

The soils of the Highland Rim were formed from both a thin loess mantle capping the Rim 1 to 4 feet deep as well as from the underlying clayey material derived from carbonate rocks and shale. Depth to bedrock is more than 5 feet in most of the area and is more than 30 feet in much of the area. The soils comprising the gently rolling terrain are low in natural fertility, strongly acid or very strongly acid, and have moderate to moderately slow permeability. The available water capacity is generally medium or high depending upon soil texture and slope, and the erosion potential is moderate to high. The cherty or clayey soils of the Highland Rim escarpment were formed on steep slopes from material derived from cherty carbonates, shale, and chert-free limestone.

The soils of the Central Basin generally formed in clayey material derived from phosphatic limestone, and in colluvium derived from cherty carbonates and shale. The depth to bedrock ranges from half a foot to greater than 10 feet, but is dominantly 3 to 8 feet. These soils have high to medium natural phosphate content and consequently are medium in overall fertility. They have a wide range in reaction, but are mostly strongly acid to slightly acid. Permeability ranges from slow in the clayey soils to moderately rapid in the loamy soils high in chert content. Available water capacity is usually medium to high. Potential for erosion is moderate to high.

Although the soils in Area 18 are discussed by physiographic region, it should be pointed-out that individual soil characteristics or properties may vary as much within a region as they do between regions. Determination of local soil characteristics and properties requires a detailed soil survey or site investigation. Additional information is available in published soil surveys for Cumberland, Putnam, and Warren Counties. Information in unpublished surveys for Van Buren and White Counties is on file in the county offices of the Soil Conservation Service, U.S. Department of Agriculture. 


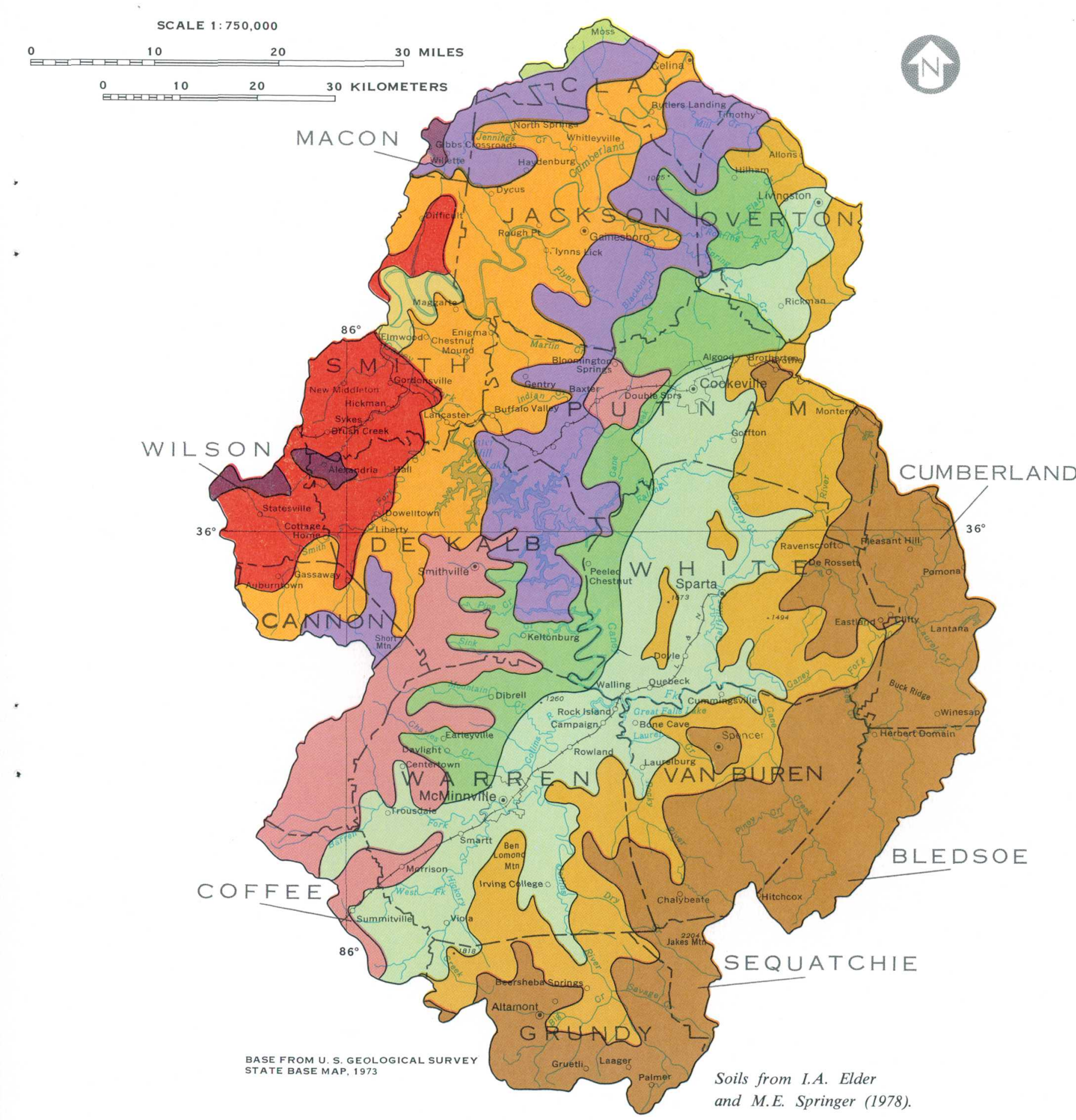

Table 2.3-1 Soil association characteristics

\begin{tabular}{|c|c|c|c|c|c|c|c|}
\hline & & & & & & & \\
\hline Soil association & $\begin{array}{l}\text { Soil depth } \\
\text { (in) }\end{array}$ & $\begin{array}{l}\text { Depth to bedrock } \\
\text { (in) }\end{array}$ & Soil reaction & $\begin{array}{l}\text { Permeability } \\
(\text { in } / h)\end{array}$ & $\begin{array}{l}\text { Available water capacity } \\
\text { (in/in) }\end{array}$ & $\begin{array}{c}\text { Slope } \\
(\%)\end{array}$ & Description \\
\hline $\begin{array}{l}\text { lartsells-Lonewood- } \\
\text { Ramsey-Gilpin }\end{array}$ & $\begin{array}{c}\text { 10-36 } \\
\text { Lonewood 40-65 }\end{array}$ & $\begin{array}{l}\begin{array}{l}10-40 \\
40-72\end{array} \\
-\end{array}$ & $3.6-6.5$ & $\begin{array}{l}0.6-6.0 \\
\text { Ramsey } 6.0-20.0\end{array}$ & $0.04-0.18$ & $0-70$ & $\begin{array}{l}\text { Undulating and rolling, moderately } \\
\text { deep well-drained, loamy soils } \\
\text { from sandstone and shale. }\end{array}$ \\
\hline Bouldin-Ramsey & $\begin{array}{l}\text { Bouldin } 60-100 \\
\text { Ramsey } 10-20\end{array}$ & $\begin{array}{l}60-120 \\
10-20\end{array}$ & $4.5-5.5$ & $\begin{array}{l}2.0-6.0 \\
6.0-20.0\end{array}$ & $0.04-0.12$ & $8-75$ & $\begin{array}{l}\text { Steep, well-drained, stony and } \\
\text { loamy soilis from collluvium, } \\
\text { sandstons sale and limstong }\end{array}$ \\
\hline \multicolumn{8}{|r|}{$\begin{array}{l}\text { sandstone, shale and limestone, } \\
\text { with rock outcrops. }\end{array}$} \\
\hline $\begin{array}{l}\text { 吕ine-Mountview- } \\
\text { Dickson }\end{array}$ & $60-96$ & $60 \rightarrow 100$ & $3.6-5.5$ & $\begin{array}{l}0.6-6.0 \\
\text { Fragipan }\end{array}$ & $\begin{array}{l}0.06-0.22 \\
0.02-0.11\end{array}$ & $0-60$ & 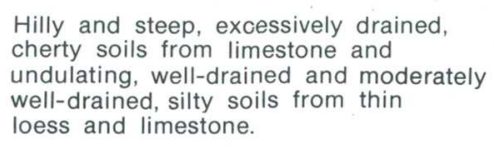 \\
\hline $\begin{array}{l}\text { Sulphura-Christian- } \\
\text { Mountview }\end{array}$ & $\begin{array}{l}\text { 40-96 } \\
\text { Sulphura } 20\end{array}$ & $\begin{array}{l}\text { Sol-100 } \\
\text { Sulphura } 10-30\end{array}$ & $3.6-6.5$ & $0.6-6.0$ & $0.09-0.22$ & $2-50$ & $\begin{array}{l}\text { Steep and hilly, well-drained, shaly, } \\
\text { cherty, and clayey soils from shale } \\
\text { and limestore with undutating silty } \\
\text { soils from thin loess and residuum. }\end{array}$ \\
\hline $\begin{array}{l}\text { Baxter-Mountview- } \\
\text { Dickson }\end{array}$ & 65-99 & $65-100$ & $4.5-6-6.0$ & $\begin{array}{l}0.6-2.0 \\
\text { Fragipan } 0.06-0.6\end{array}$ & $\begin{array}{l}0.08-0.22 \\
0.02-0.11\end{array}$ & $0-60$ & 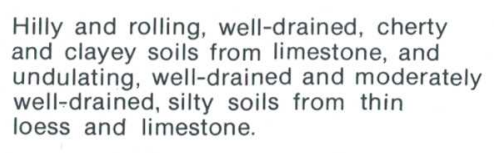 \\
\hline Christian-Mountview & $40-96$ & $60-100$ & $3.6-6.5$ & $0.6-6.0$ & $0.10-0.22$ & $2-45$ & 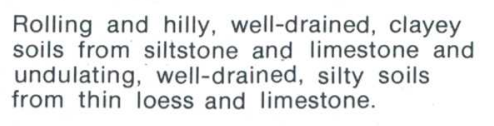 \\
\hline 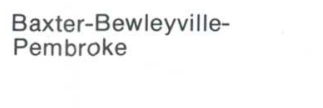 & 72-100 & $72-100$ & $4.5-6.60$ & $0.6-2.0$ & $0.08-0.23$ & $0-60$ & $\begin{array}{l}\text { Rolling and undulating, woll-drained, } \\
\text { cherty, clayey and sitity soils from } \\
\text { limestone, thin loess and alluvium. }\end{array}$ \\
\hline $\begin{array}{l}\text { Waynesboro-Decatur- } \\
\text { Bewleyville-Curtistown }\end{array}$ & $60-72$ & $60-80$ & $4.5-6-6.0$ & $0.6-2.0$ & $0.10-0.22$ & $0-30$ & $\begin{array}{l}\text { Undulating and rolling, well-drained, } \\
\text { clayey and loamy soils from alluvium } \\
\text { and thin loess. }\end{array}$ \\
\hline $\begin{array}{l}\text { Dickson-Mountview- } \\
\text { Guthrie }\end{array}$ & & $\begin{aligned} & 3.6-5.5 \\
= & \text { THE CENTRA }\end{aligned}$ & $\begin{array}{l}0.6-2.0 \\
\text { Fragipan } 0.06-0.6 \\
\text { AL BASIN }\end{array}$ & $\begin{array}{l}0.10-0.22 \\
0.02-0.11\end{array}$ & & $\begin{array}{l}\text { Undulating well-drained to poorly } \\
\text { drained, sitity soils from thin loess } \\
\text { and limestone. }\end{array}$ \\
\hline Dellrose-Mimosa-Bodine & $40-72$ & 40-80 & $3.6-6.0$ & $0.2-6.0$ & $0.06-0.20$ & $2-60$ & $\begin{array}{l}\text { lilly and steep, deep and moderately } \\
\text { deep, well-drained, cherty and t layey } \\
\text { soils from colluvim, phosphatic } \\
\text { limestone, cherty limestone and shate. }\end{array}$ \\
\hline Mimosa-Armour & $40-80$ & 40-120 & $4.5-6.0$ & $0.2-6.0$ & $0.10-0.22$ & $0-35$ & 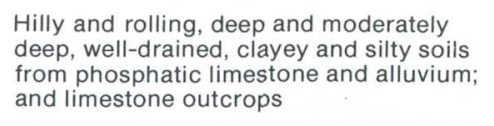 \\
\hline $\begin{array}{l}\text { Stiversville-Hampshire- } \\
\text { Inman }\end{array}$ & 20-50 & $20-60$ & $4.5-7.8$ & $0.2-6.0$ & $0.06-0.22$ & $3-40$ & $\begin{array}{l}\text { Hilly and rolling, deep and moderately } \\
\text { doep, wevlldrained, loamy and clayey } \\
\text { soils from phosphetic limestone and } \\
\text { shale. }\end{array}$ \\
\hline Maury-Braxton-Harpeth & $60-80$ & $60-80$ & $4.5-6.5$ & $0.6-6.0$ & $0.12-0.23$ & $0-25$ & 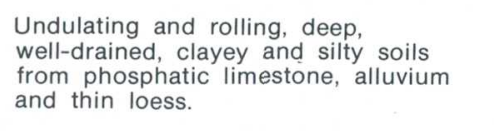 \\
\hline Talbott-Gladeville-Barfield & 6-37 & $6-40$ & $5.1-8.4$ & $0.2-2.0$ & $0.04-0.18$ & $0-40$ & $\begin{array}{l}\text { Undulating and rolling, moderately } \\
\text { deep to shallow, well-drained, clayey } \\
\text { soils from limestone; and rock } \\
\text { outcrops. }\end{array}$ \\
\hline
\end{tabular}

Data are from U.S. Soil Conservation Service Soil Interpretation Records (SCS-Soils-5). 


\title{
2.0 GENERAL FEATURES (Continued) \\ 2.4 Land Cover/Land Use
}

\section{COAL RESOURCES AREA COVERED MAINLY BY FOREST}

\author{
Land cover in the Cumberland Plateau section is predominately \\ forest while that in the Highland Rim and Central Basin sections \\ is mainly pasture or cropland.
}

\begin{abstract}
More than two-thirds of the Cumberland Plateau is covered by forest as shown on the accompanying land cover map (fig. 2.4-1) which was derived from Landsat satellite imagery taken April 14, 1973. The remaining one-third of the Plateau has been cleared and is used for agriculture, mining, or recreation. In figure 2.4-1, covered ground is associated chiefly with agricultural use including pasture and cropland; bare ground is associated with agriculture or mining, coal spoil is associated directly with mining, and water is associated with recreation communities. Although the amount of bare ground is small, it varies from time to time due to clearing for planting new tree farms, for renewing pasture or crops, or for surface mining. Regardless of the purpose, clearing the land to bare soil greatly accelerates the rate of erosion and increases the sediment load of streams draining the affected areas.
\end{abstract}

A very small part of the Plateau is covered by water in reservoirs at parks and vacation-retirement communities. The escarpment separating the Cumberland Plateau from the Highland Rim is entirely in forest.

Most of the Highland Rim is in agriculture, which is shown as either covered ground or bare ground (fallow fields) in figure 2.4-1. Wood lots are small and scattered throughout the region. The Highland Rim escarpment, like the Cumberland Plateau escarpment, is forested.

Land cover in the Central Basin part of the area is about equally divided between forest on steep slopes and covered ground in valleys. Center Hill Lake and Cordell Hull Reservoir cover only a small part of the Central Basin, but they are important recreational areas. 


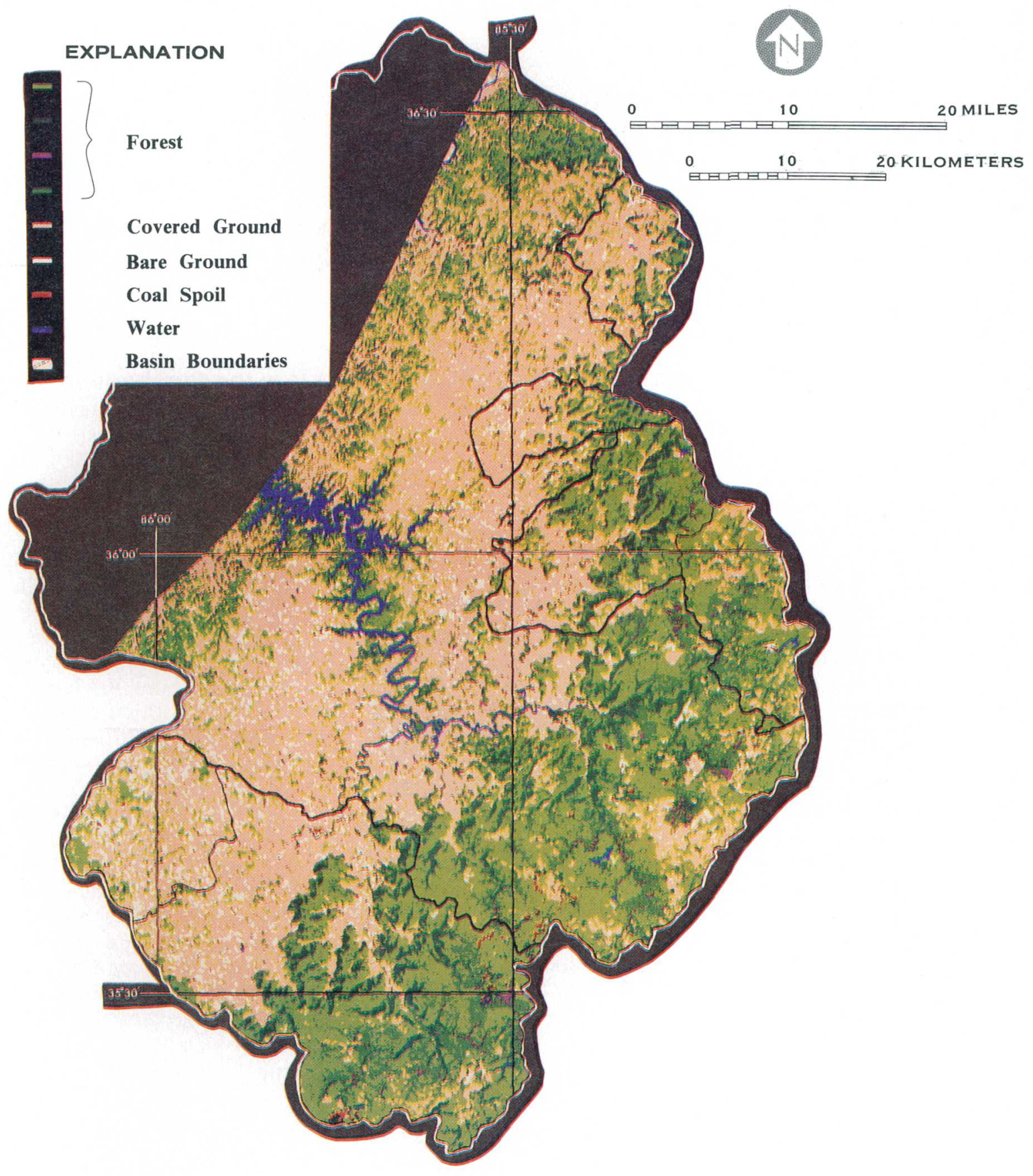

Figure 2.4-1 Land cover in the Cumberland Plateau and Highland Rim of Area 18 


\subsection{GENERAL FEATURES (Continued) 2.5 Surface Drainage}

\section{CUMBERLAND RIVER AND CANEY FORK ARE THE LARGEST STREAMS}

\section{All surface drainage in Area 18 flows into the Cumberland River. The Caney Fork drains all of the coal resources area.}

Area 18 has a total surface drainage of 3,380 $\mathrm{mi}^{2}$. All surface drainage is to the Cumberland River, which flows southwesterly across the northern tip of the area. Caney Fork and its tributaries drain 2,585 $\mathrm{mi}^{2}, 76$ percent of the surface area. Drainage divides of those streams and the divides of the three $\mathrm{Hy}-$ drologic Units, as defined by the U.S. Geological Survey in cooperation with the U.S. Water Resources Council, are shown in figure 2.5-1 (1974). The drainage area of each Hydrologic Unit and the largest streams. in the area are given in table 2.5-1.

The Caney Fork and its major tributaries from Falling Water River to the headwaters drain the coal resources area. These streams have developed a random drainage pattern flowing in deeply incised channels off the Plateau onto the Highland Rim. The descent from the Plateau to the Highland Rim is generally about 1,000 feet and the transition occurs within a few thousand feet in distance sometimes creating scenic waterfalls. The Caney Fork continues across the Highland Rim and onto the Central Basin completing its course across the three physiographic regions.

Other streams in Area 18 originate either on the Highland Rim or Central Basin and flow into the Caney Fork or directly into the Cumberland River. The transition from the Highland Rim to the Central Basin occurs over a few miles in distance with a drop in elevation of about 300 feet. Stream channels are deeply incised in this transition zone. All streams within Area 18, except the Cumberland River, originate and end within the boundaries of the area.

The Cumberland River is impounded in Area 18 by Old Hickory and Cordell Hull dams which create a navigable waterway. Two hydropower and flood control dams impound the Caney Fork. Center Hill dam is the largest of these and is a major hydropower and flood control dam. Great Falls dam, farther upstream on the Caney Fork, is primarily a hydropower dam having little floodwater storage. Closure dates and storage capacities for these four dams are listed below:

Dam

Closure date Maximum storage capacity (acre-feet)

$\begin{array}{lrr}\text { Old Hickory } & 1954 & 544,700 \\ \text { Cordell Hull } & 1967 & 310,800 \\ \text { Center Hill } & 1948 & 2,092,200 \\ \text { Great Falls } & 1916 & 50,400\end{array}$




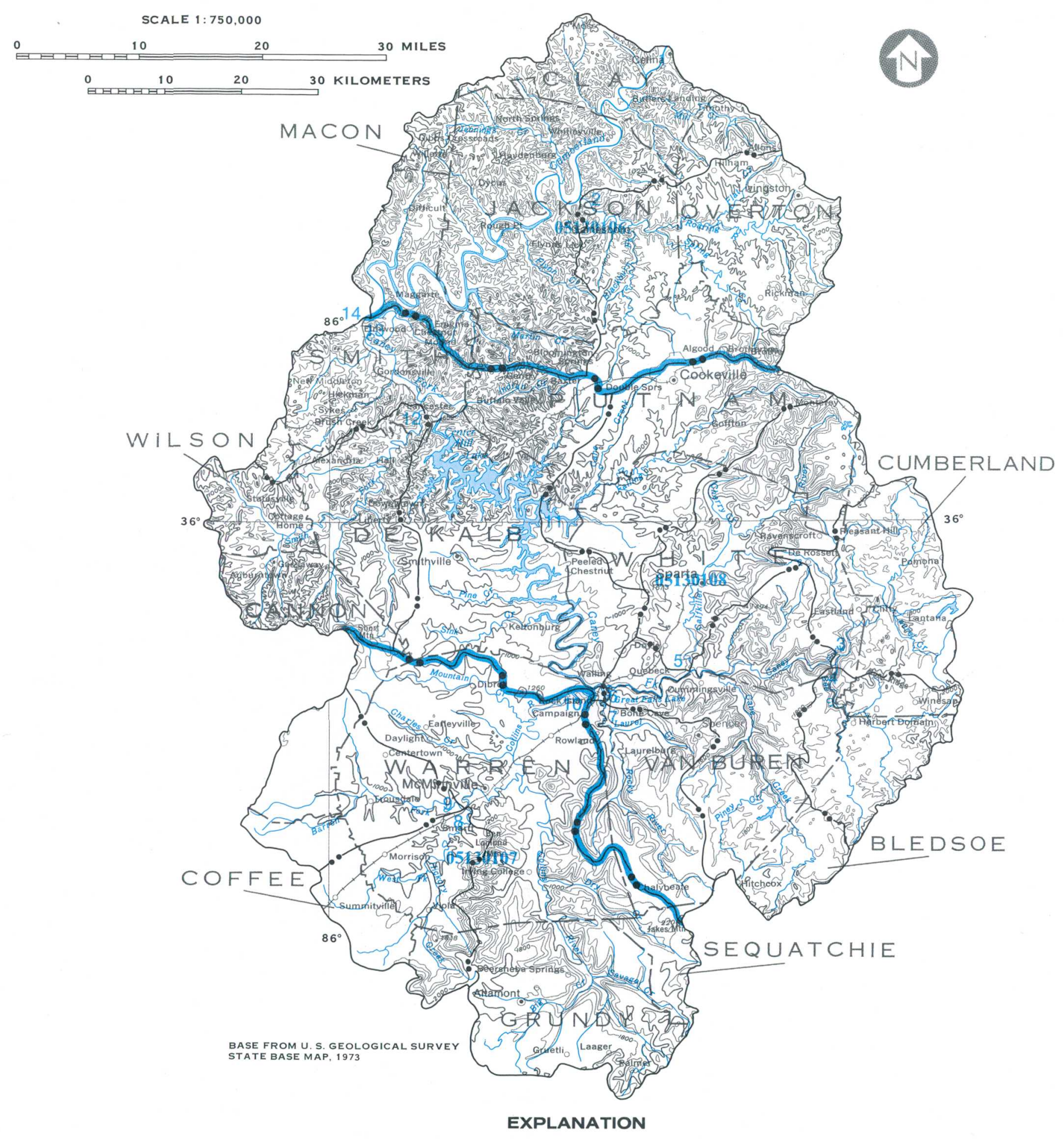

Table 2.5-1 Drainage areas of major stream basins Basin No.
on Map

Cumberland River below Obey River

7,307

Cumber

300

Caney Fork above Bee Creek

Bee Creek at mouth

Calfkiller River at mouth

147

Caney Fork above Rocky River

Rocky River at mouth

766

Hickory Creek at mouth

Barren Fork at mouth

13

Barren Fork at mouth

Falling Water River at mouth

Smith Fork at mouth

Caney Fork at mouth

Cumberland River below Caney Fork (at downstream area boundary)

$$
\text { Total Area } 18
$$

Hydrologic Unit 05130106

-.. Drainage basin boundary

05130107 Hydrologic Unit number

6 Basin number

Figure 2.5-1 Drainage basins 


\subsection{GENERAL FEATURES (Continued) \\ 2.6 Coal-Mining Activities}

\section{COAL-MINING ACTIVITIES OCCUR THROUGHOUT CUMBERLAND PLATEAU REGION}

\section{Surface coal mining is widespread throughout the Cumberland Plateau region. One deep mine is operated in Bledsoe County.}

Location of State mining permits issued by the Tennessee Department of Conservation since 1972 are shown in figure 2.6-1. Permits labeled as active were issued in 1979 or 1980 . State mining permits are required to be renewed annually, hence, those issued prior to 1979 were considered inactive.

Coal is usually mined by stripping away overburden or overlying rock formations in order to load and haul the coal overland in trucks. Commonly, surface mining is done in Area 18 by stripping along the contours (contour mining) of hills and mountains where the edges of coal seams are mined as far back into the mountain as it is economically feasible (fig. 2.6-2). In some mining operations, additional coal is extracted by augering the coal seam after the stripping operation is completed.

Contour mining leaves bare earth and rocks, high-walls (vertical to near vertical bare earth and rock walls created by slicing a strip off the side of a mountain), benches (level to near level floor of the stripped area used for access and hauling), and spoil banks (unstable, loose earth and rocks pushed or dumped on the bench or down the mountainside). Drastic alteration to the environment can be prevented or lessened by reclaiming the mined area during or after mining. 


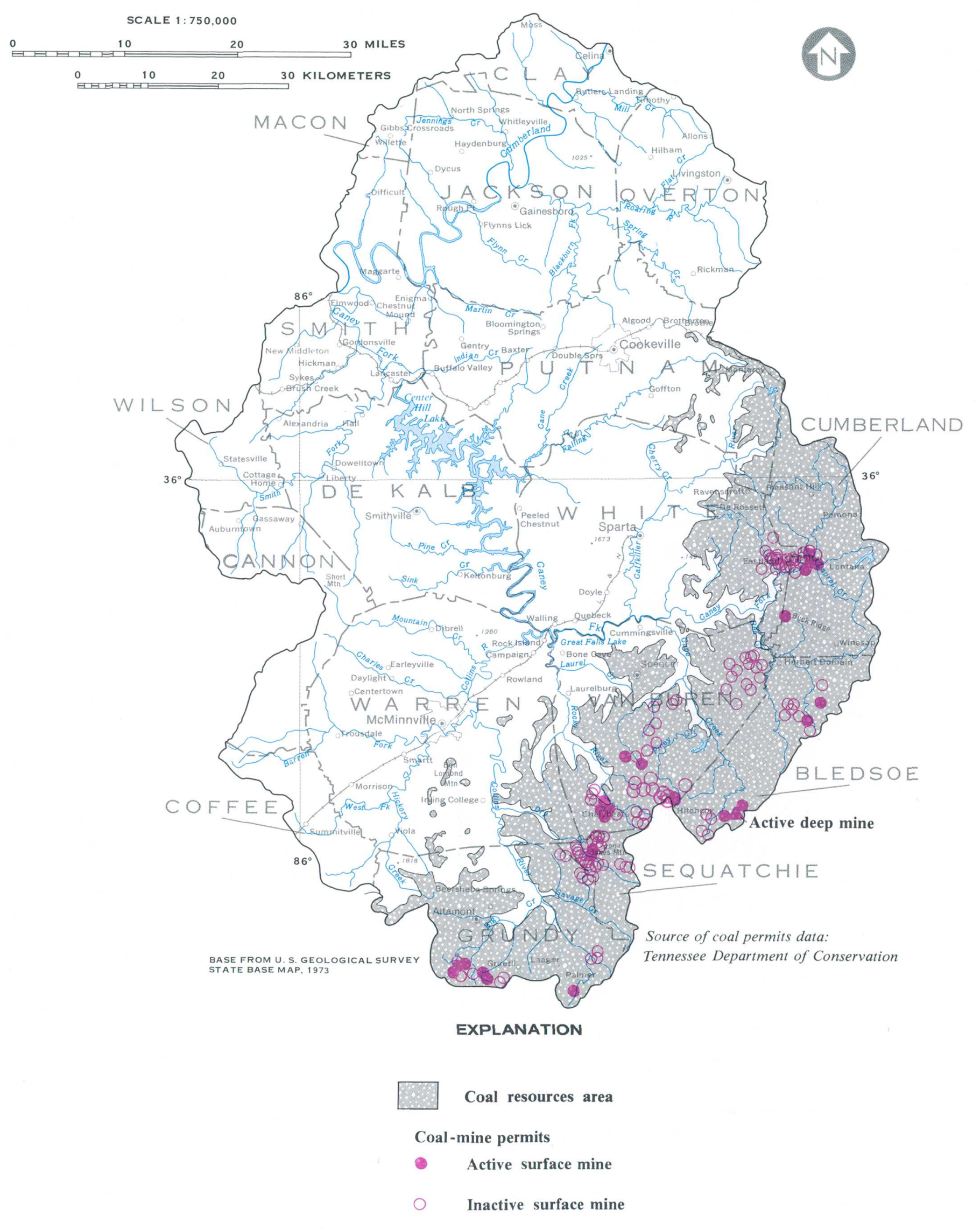

Fig. 2.6-1 Coal-mining activities

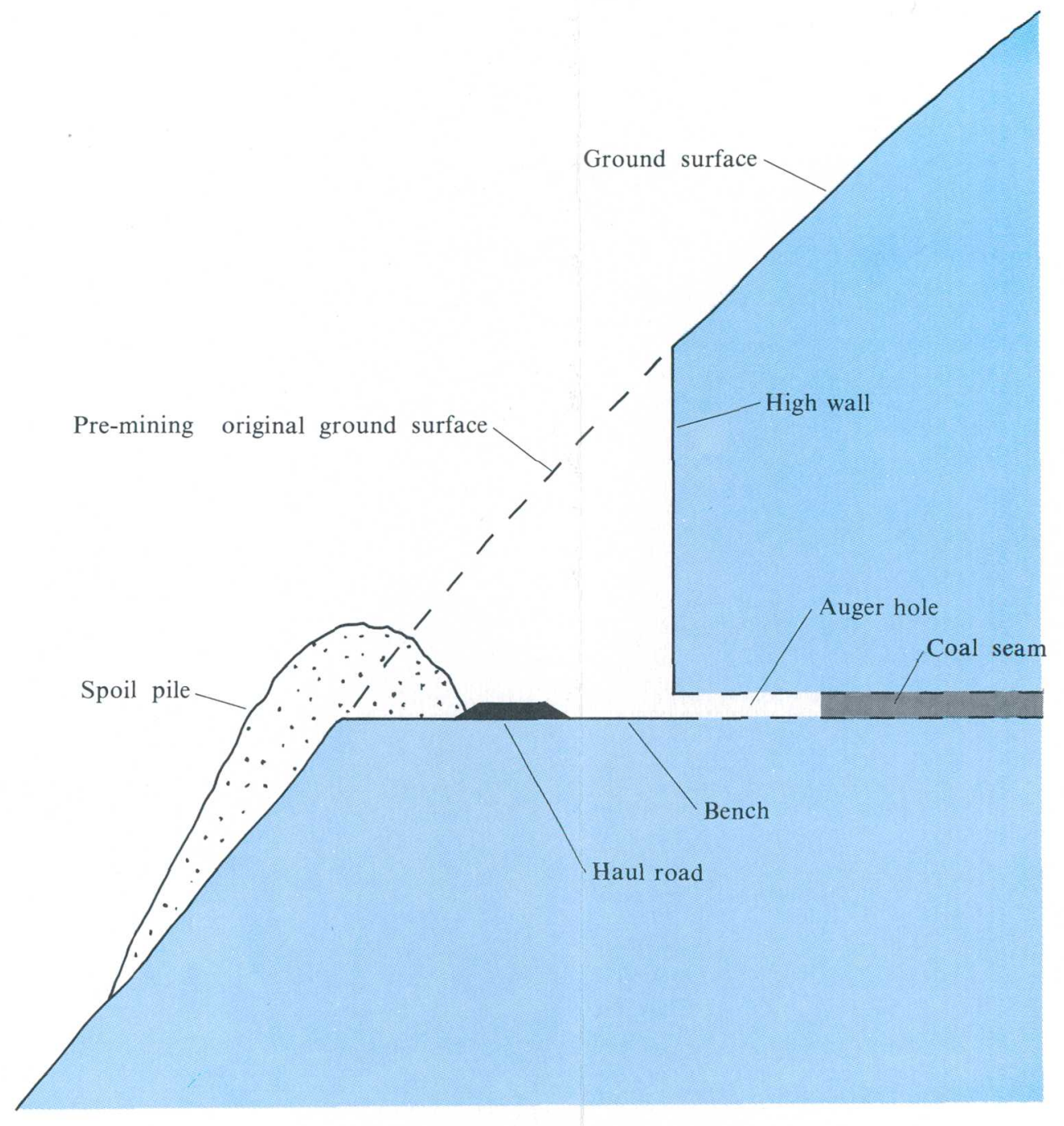

Figure 2.6-2 Section of typical contour (strip) mining site 


\title{
2.0 GENERAL FEATURES (Continued) \\ 2.7 Climate
}

\section{CLIMATE OF AREA 18 HAS PRONOUNCED SEASONAL VARIATIONS}

\begin{abstract}
Mean annual precipitation averages about 52 inches with extremes of of about 35 and 70 inches. Average annual temperature is about $60^{\circ} \mathrm{F}$.
\end{abstract}

Area 18 encompasses parts of two climatological divisions, Middle Tennessee and the Cumberland Plateau (fig. 2.7-1). The average annual temperature is about $60^{\circ} \mathrm{F}$ with extremes seldom above $100^{\circ} \mathrm{F}$ or below $-5^{\circ} \mathrm{F}$. Temperatures are above $90^{\circ} \mathrm{F}$ about 75 days per year. There is a long frost-free season of about 200 days from early April to late October. The Cumberland Plateau region has a slightly cooler average annual temperature because of the higher elevation. Temperature generally decreases about $3 \mathrm{~F}^{\circ}$ per 1,000 feet of increased elevation and rainfall generally increases with an increase in elevation.
The average annual precipitation is about 52 inches, but ranges from about 35 inches in dry years to about 70 inches in wet years. Thunderstorms which often produce locally heavy rainfall occur on about 56 days per year and are sometimes accompanied by damaging winds and extreme changes in temperature. The 10-year 24-hour rainfall (fig. 2.7-1) is a useful parameter for hydrologic studies. Maximum, minimum and mean monthly precipitation for each climatological division are also shown in figure 2.7-1. 

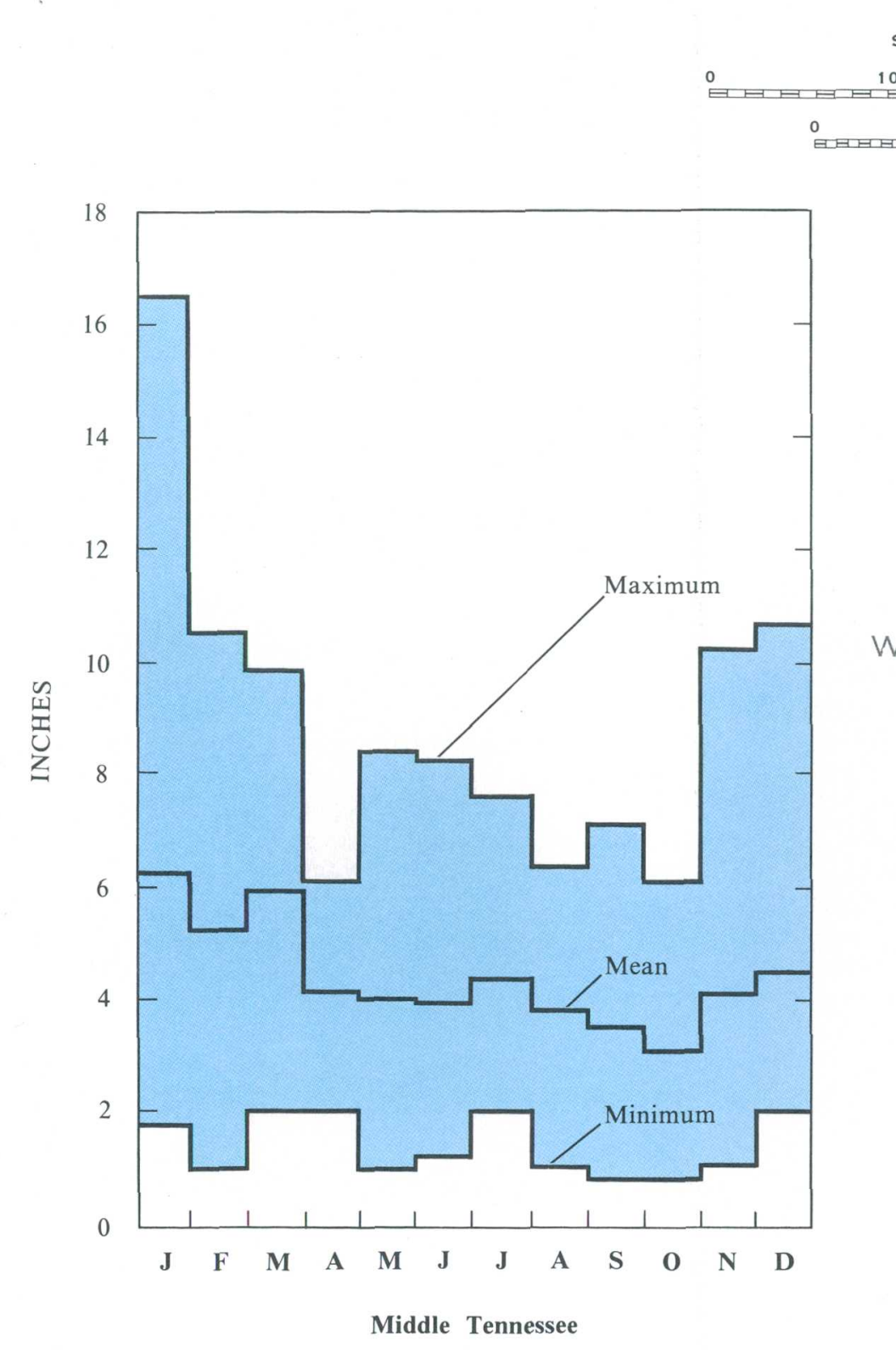

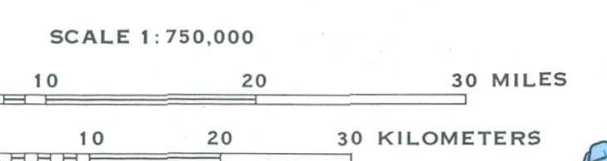

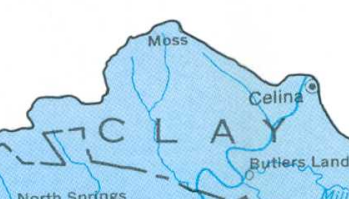

(10)

Monthly maximum, minimum, and mean precipitation (1931-55)

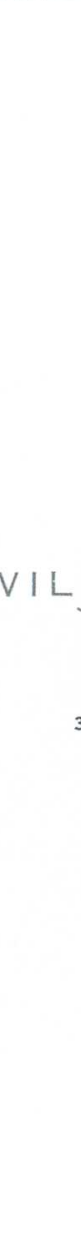

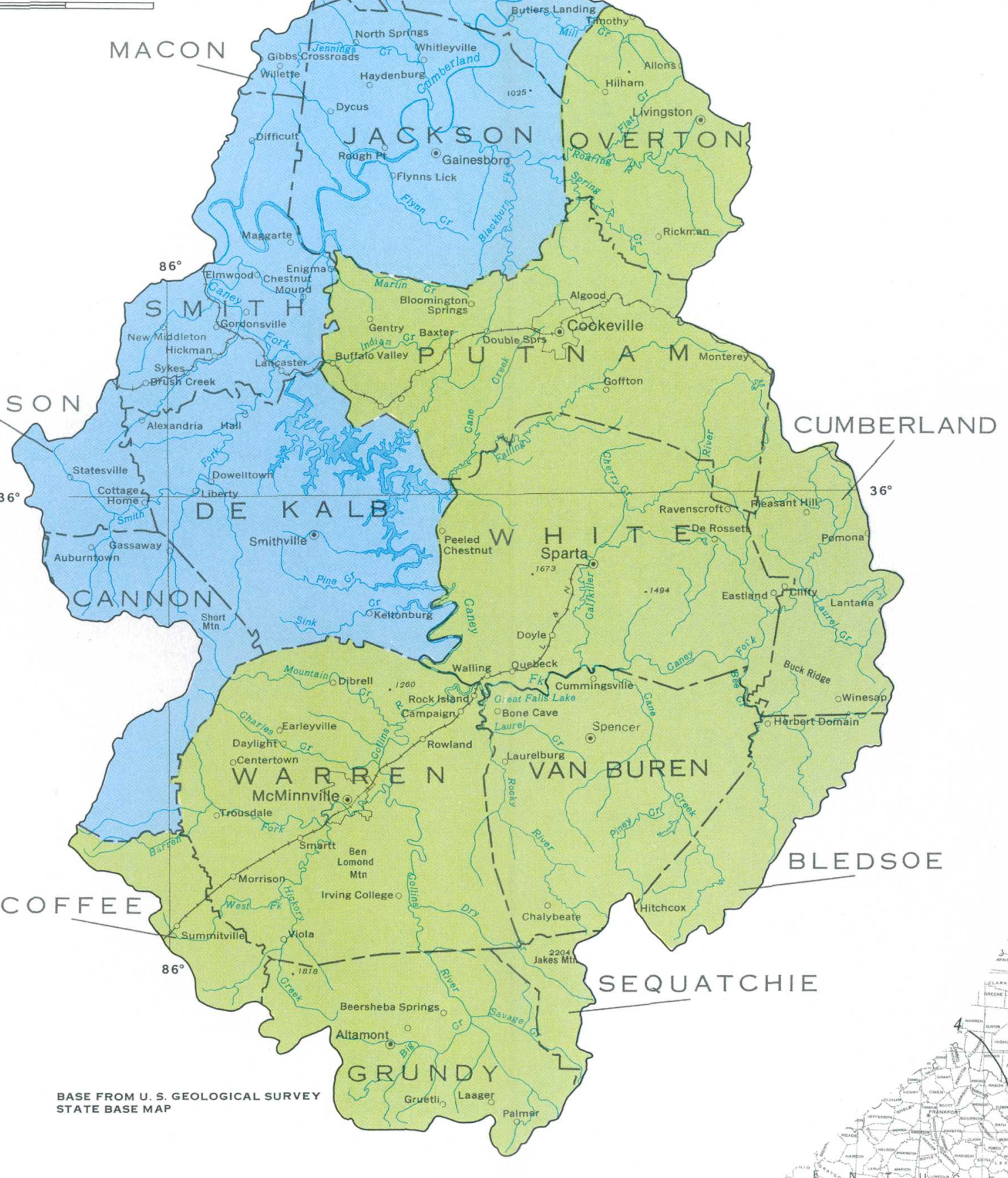

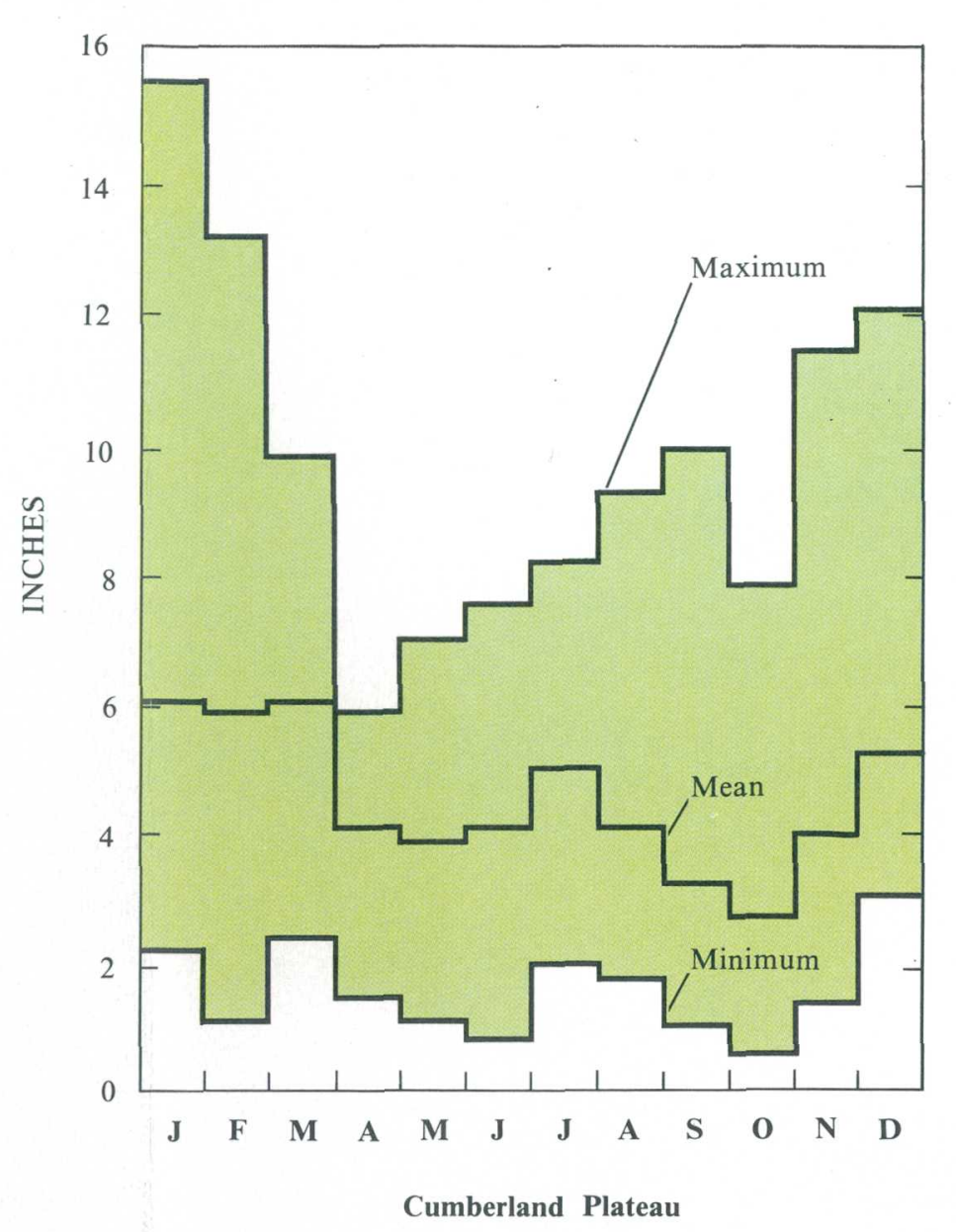

Monthly maximum, minimum, and mean precipitation (1931-55)

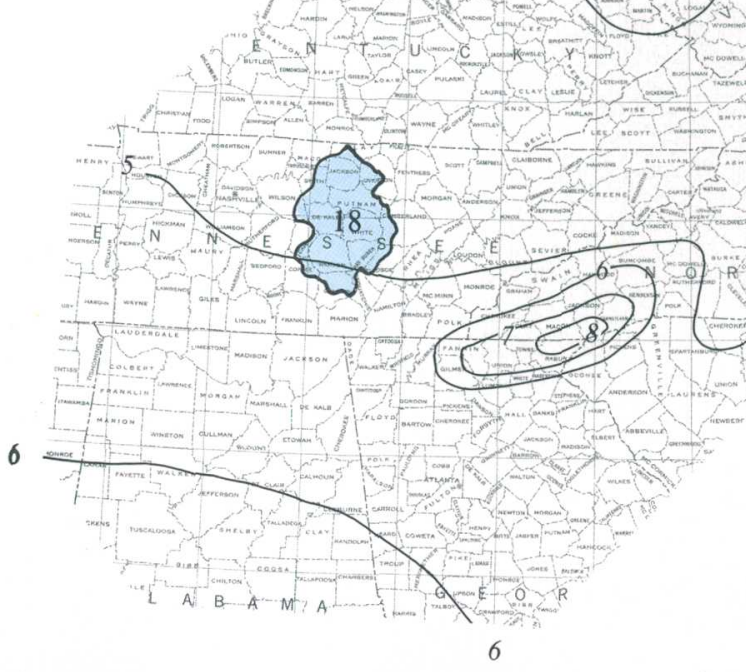

2.0 GENERAL FEATURES (Continued) 2.7 CLIMATE 


\title{
3.0 USE CLASSIFICATION OF STREAMS
}

\section{STREAM USES CLASSIFIED BY STATE AGENCY}

\author{
Most streams in Area 18 are classified for use as fish, recreation, \\ irrigation, and livestock and wildlife purposes. Other classifications \\ pertaining to streams include domestic and industrial water supply, \\ and navigation.
}

Section 208 of the Federal Water Pollution Control Act Amendments of 1972 (Public Law 92-500) defined criteria for developing and implementing areawide water quality management plans. In compliance with that Act and Amendments, the Tennessee Department of Public Health, Division of Water Quality Control developed and published a water quality management plan for Tennessee (1978). Included in that plan are use classifications for most primary streams in the State. Criteria for water conditions are defined for each use classification (table
3.0-1). The stream reaches and use classifications are shown in figure 3.0-1 and listed in Appendix 1.

The criteria used to develop each classification, and the quality of water parameters, are defined in the State's water management plan. When the State regulatory agencies develop plans to implement the guidelines in the Surface Mining Control and Reclamation Act of 1977 (P. L. 95-87), standards for some of the quality of water criteria described above will most likely be reviewed in light of standards defined in the Act. 


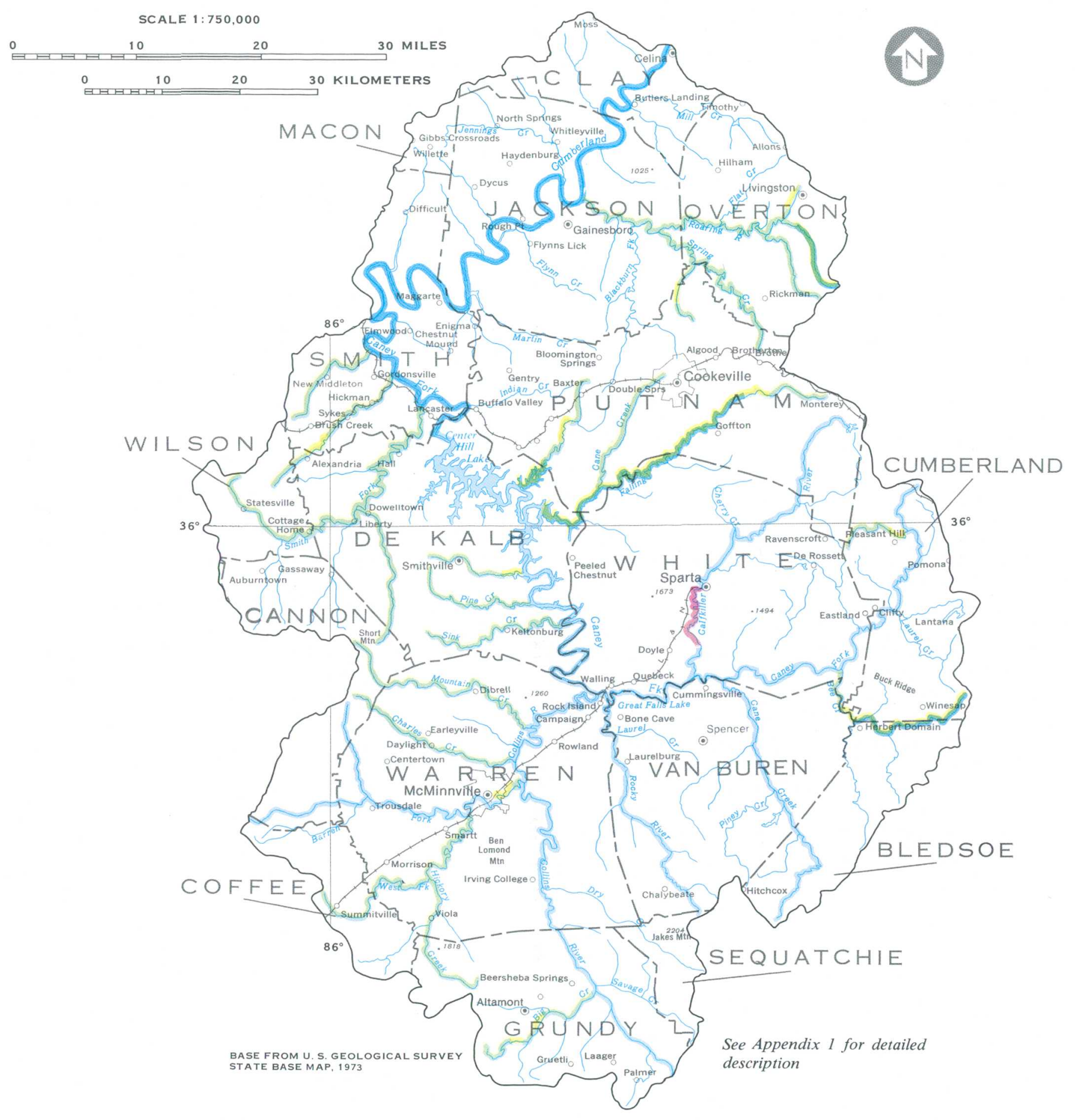

Figure 3.0-1 Stream use classification

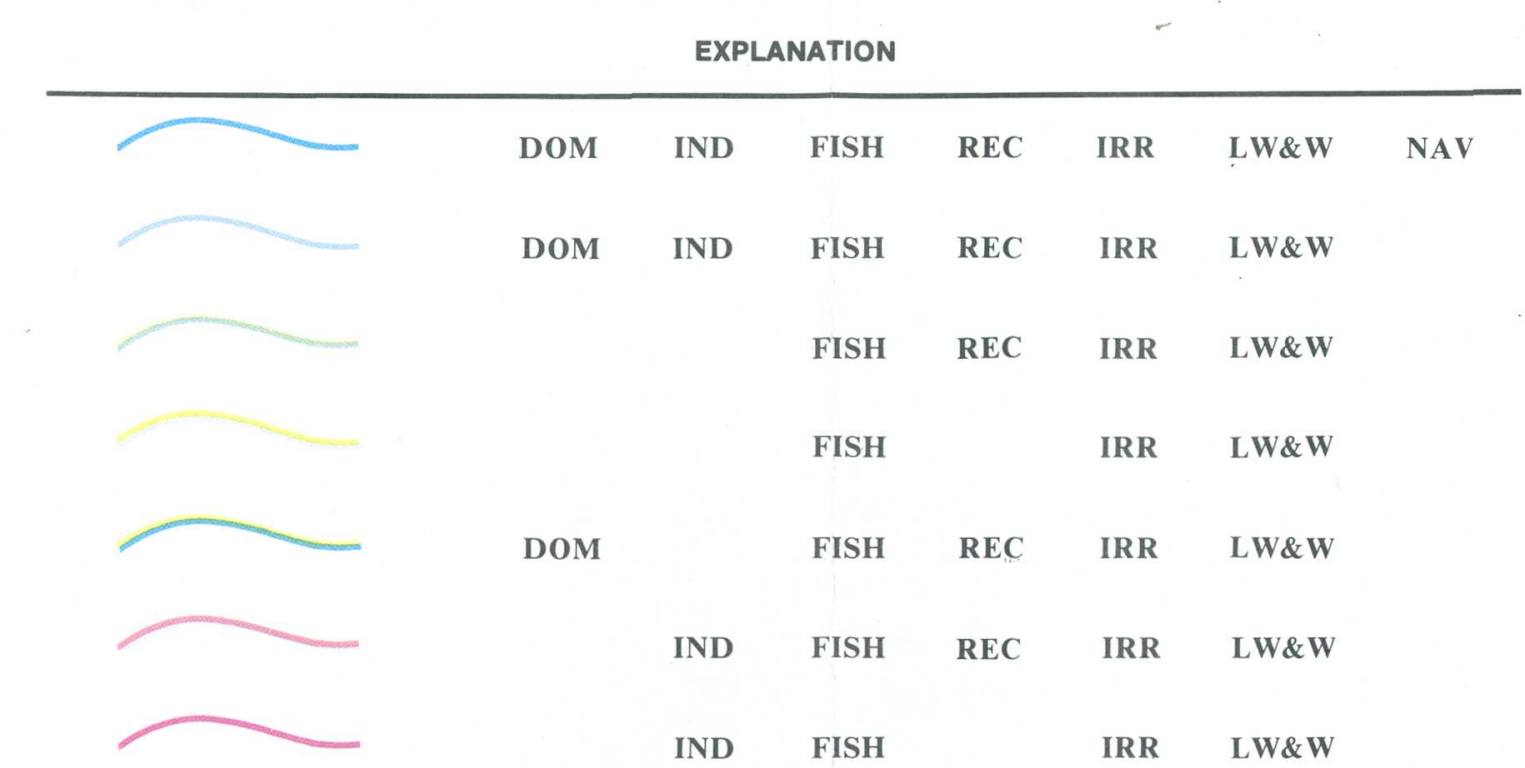

Table 3.0-1 Criteria for water condition

\begin{tabular}{|c|c|c|c|c|c|c|c|c|c|c|c|c|}
\hline & \multirow[b]{2}{*}{ 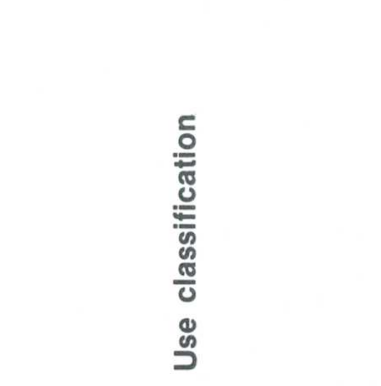 } & \multicolumn{11}{|c|}{ Parameters for which criteria are defined } \\
\hline & & 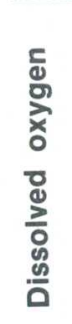 & $\frac{I}{2}$ & 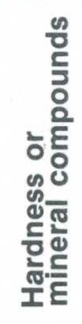 & 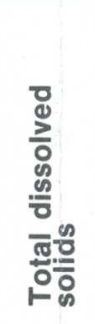 & 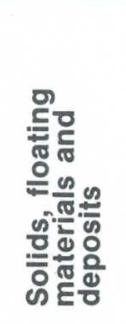 & 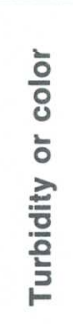 & 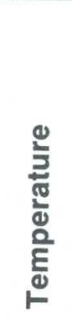 & 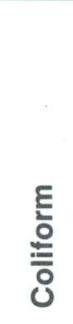 & 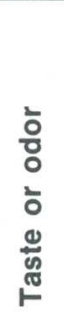 & 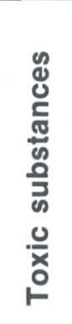 & 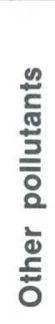 \\
\hline DOM - & Domestic Water Supply & $x$ & $\mathrm{x}$ & $x$ & $x$ & $x$ & $x$ & $\mathrm{x}$ & $\mathrm{x}$ & $x$ & $x$ & $\mathrm{x}$ \\
\hline IND - & Industrial Water Supply & $x$ & $\mathrm{x}$ & $x$ & $x$ & $\mathrm{x}$ & $x$ & $\mathrm{x}$ & & $x$ & $x$ & $x$ \\
\hline FISH - & Fish and Aquatic Life & $\mathrm{x}$ & $\mathrm{x}$ & & & $\mathrm{x}$ & $\mathrm{x}$ & $\mathrm{x}$ & $\mathrm{x}$ & $\mathrm{x}$ & $\mathrm{x}$ & $\mathrm{x}$ \\
\hline REC - & Recreation & $x$ & $\mathrm{x}$ & & & $\mathrm{x}$ & $\mathrm{x}$ & $x$ & $x$ & $\mathrm{x}$ & $\mathrm{x}$ & $\mathrm{x}$ \\
\hline IRR - & Irrigation & $\mathrm{x}$ & $\mathrm{x}$ & $x$ & & $\mathrm{x}$ & & $\mathrm{x}$ & & & $\mathrm{x}$ & $x$ \\
\hline LW\&W - & $\begin{array}{l}\text { Livestock Watering } \\
\text { and Wildlife }\end{array}$ & $x$ & $\mathrm{x}$ & $x$ & & $x$ & & $x$ & & & $x$ & $x$ \\
\hline NAV - & Navigation & $x$ & & $x$ & & $\mathrm{x}$ & & $\mathrm{x}$ & & & $\mathrm{x}$ & $x$ \\
\hline
\end{tabular}




\title{
4.0 HYDROLOGIC NETWORKS \\ 4.1 Surface Water
}

\section{INFORMATION ON SURFACE WATER AVAILABLE AT 96 LOCATIONS}

\author{
Some streamflow records in Area 18 have been collected for more \\ than 50 years. Miscellaneous water-quality and suspended \\ sediment data are not as plentiful, but most of the information \\ was collected in the last 15 years. In 1979 data collection was \\ intensified in response to the Surface Mining Control and Reclamation Act.
}

Location of 96 hydrologic stations where the quantity and quality of streamflow has been measured are shown in figure 4.1-1. Some streamflow stations have been operated for more than 50 years. However, most water quality and sediment information has been collected in the last 15 years. A listing of each station, period of operation, type of record, and other pertinent information is included in Appendix 2 .

In 1979, in response to the Surface Mining Control and Reclamation Act, the network was expanded by 16 additional quality of water stations. Water quality information includes field and laboratory analyses. Some of the more prevalent parameters include: temperature; specific conductivity; $\mathrm{pH}$; dissolved and total minerals content; and dissolved and total metals content. Suspended sediment is also collected at 17 stations which were activated in 1979. In- formation includes suspended-sediment concentrations and total-sediment loads.

Various types of discharge information are available depending on the purpose for which the streamflow station was established and operated. Major types include (1) continuous records of water levels and discharge, (2) records of flood stages and flood discharges, (3) instantaneous discharge measurements of base flow (no storm runoff), and (4) instantaneous measurements of variable streamflow rates.

Most of the water quality and suspended sediment stations were established to better define the characteristics of the streams as required by the Act. Station information as well as actual surface water quantity and quality data can be obtained from Survey computer files through the National Water Data Exchange (NAWDEX) or from the annual data publication "Water Resources Data for Tennessee." 


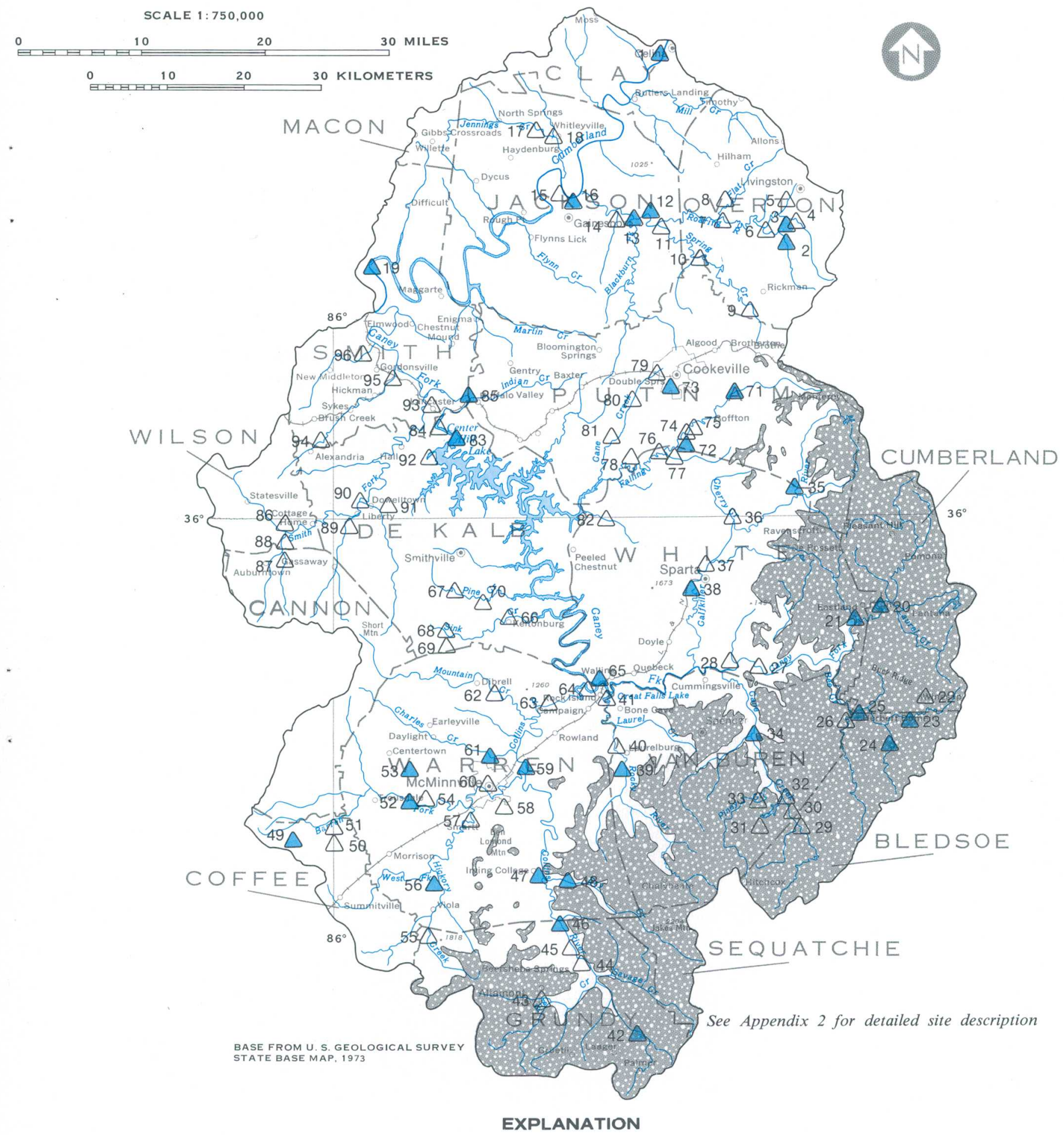

Coal resources area

$\begin{array}{ll}\Delta^{7} & \text { Active station and number } \\ \Delta^{2} & \text { Inactive station and number }\end{array}$

Figure 4.1-1 Surface-water network 


\subsection{HYDROLOGIC NETWORKS (Continued) \\ 4.2 Ground Water}

\section{GROUND WATER DATA AVAILABLE AT 44 LOCATIONS}

Information on ground water has been collected at 30 wells and 14 springs. Types of information include water-level measurements, water-quality analyses, and discharge measurements of springs.

The locations of 30 wells and 14 springs where water level, discharge, and water quality information has been collected are shown in figure 4.2-1. A listing of stations, locations, period of operation, type of record, and other pertinent information is included in Appendix 3.

Types of information available for wells may in- clude (1) periodic water level measurements, (2) continuous records of water levels, and (3) dissolved and total constituents. Station information as well as actual data can be obtained from Survey computer files through the National Water Data Exchange (NAWDEX) or from the annual data publication "Water Resources Data for Tennessee." 


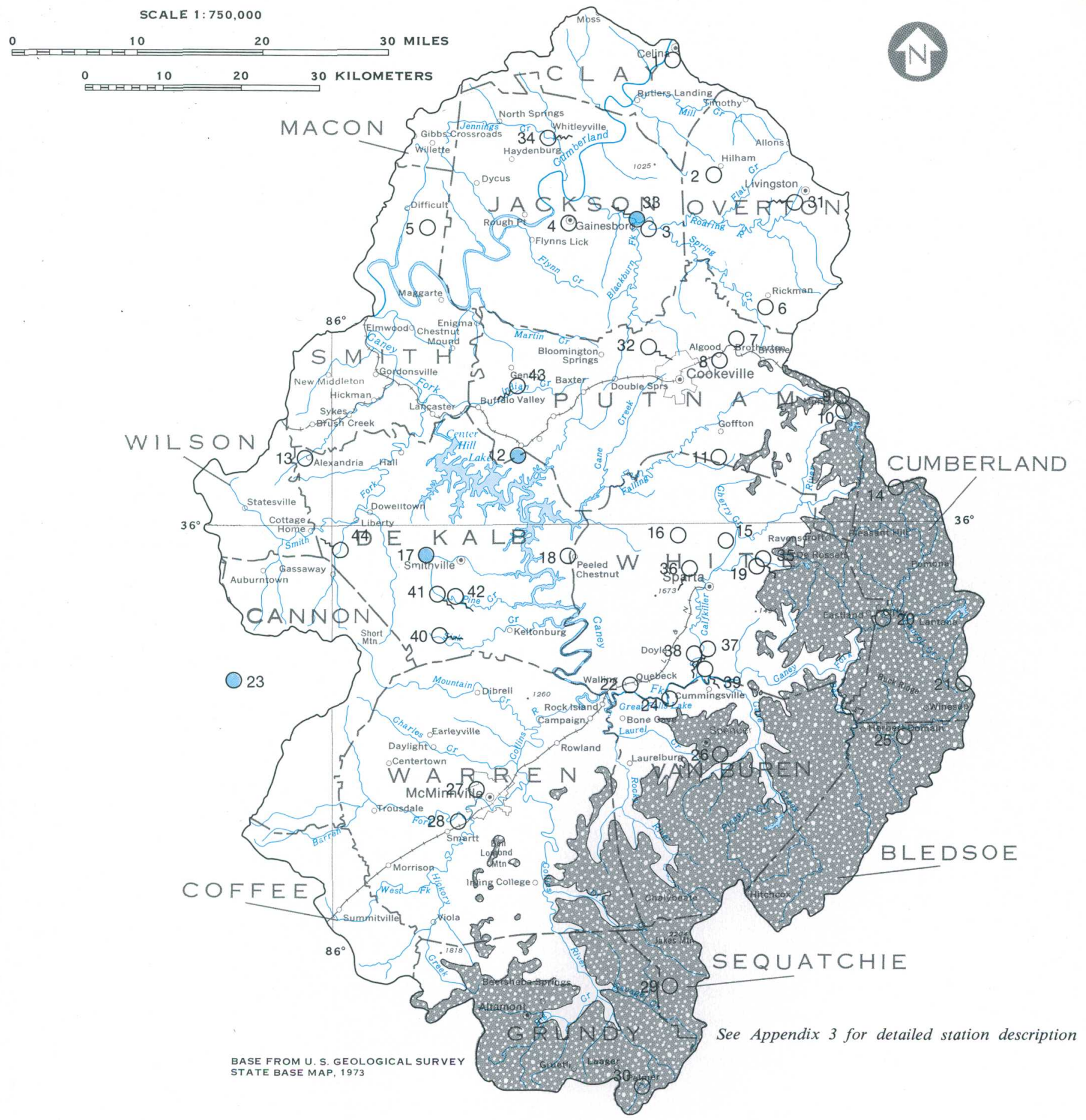

EXPLANATION

Coal resources area

Well and number Spring and number

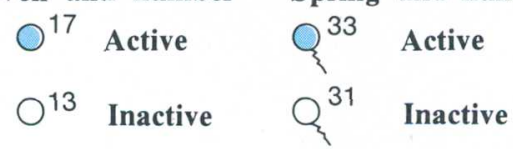

Figure 4.2-1 Ground-water network 


\title{
5.0 SURFACE WATER \\ 5.1 Streamflow Characteristics
}

\section{STREAMFLOW VARIES WITH TIME AND PLACE}

\author{
Differences in topography, slope, soils, and geology contribute to \\ the variability of streamflow. The average annual runoff is \\ approximately 22 inches.
}

\begin{abstract}
Surface water is the water stored in lakes, ponds, and reservoirs and that flowing in streams. The volume of stored water is relatively stable although there is some seasonal fluctuation. Streamflow, the largest component of surface water, is highly variable with time and place. It varies from season to season in a similar pattern to the seasonal variation in rainfall (see fig. 2.7-1) and varies from stream to stream because of differences in drainage basin size and other physical characteristics (table 5.1-1). It is made up of two components; direct runoff that supplies most of the volume of streamflow during flood periods, and runoff from ground-water storage that feeds the streams during the periods of no direct runoff. The average annual runoff from any area in Tennessee can be approximated as the mean annual precipitation for the area minus approximately 30 inches of evapotranspiration. From this approximation, the average annual runoff for Area 18 is about 22 inches.
\end{abstract}

Area 18 encompasses parts of three physiographic regions (fig. 5.1-1) which have significant differences in topography, slope, soils, and geology (see section 2.0). All of these factors contribute to the variability of streamflow, especially during the 250 days per year on the average when no rainfall occurs.

The streams in Area 18 can be classified and related to physiography by: (1) Those draining areas totally within one physiographic region whose flow characteristics are determined by that region; and (2) those draining areas from more than one physiographic region whose streamflow is an integration of the characteristics of the entire region which it drains. Table 5.1-1 shows monthly mean discharge as a percentage of the annual mean for selected streams in both of the above categories. No real physiographic trends can be detected in this table except that the Cumberland Plateau station values for September, which is usually a dry month, seem to be low. This table also illustrates the seasonal variability of individual streams.

A typical hydrograph showing flow variability for the Collins River near McMinnville during the 1977 water year (October 1976 to September 1977) is shown in figure 5.1-2. Also shown on this figure is the maximum and minimum instantaneous discharge for the year and the average discharge for the period of record. Another way of illustrating this flow variability for one year is shown in figure 5.1-3 which shows mean monthly flow and the maximum and minimum mean daily flow per square mile for each month of 1977. Figure 5.1-4 illustrates the long-term monthly variability of Collins River. 


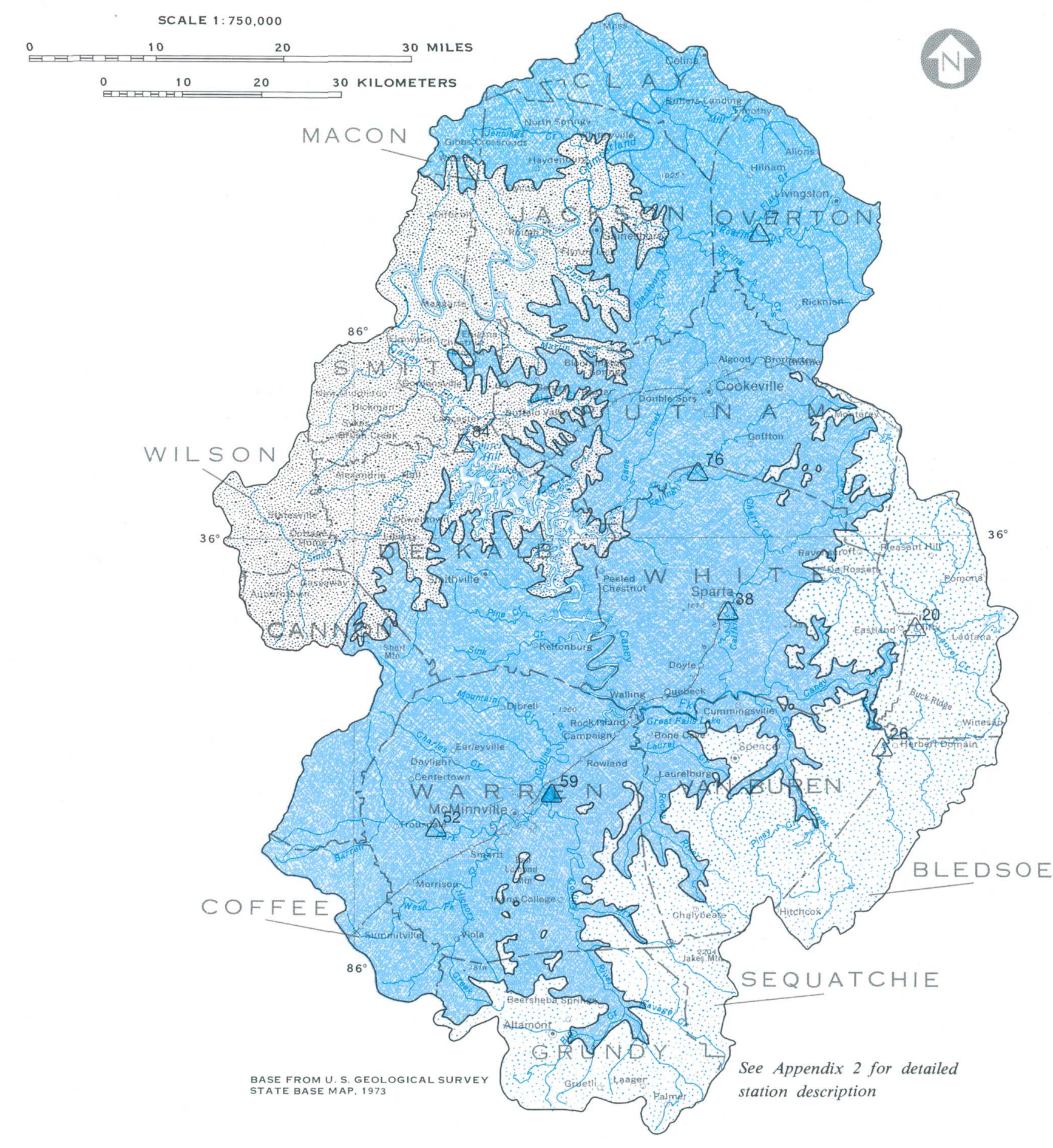

EXPLANATION

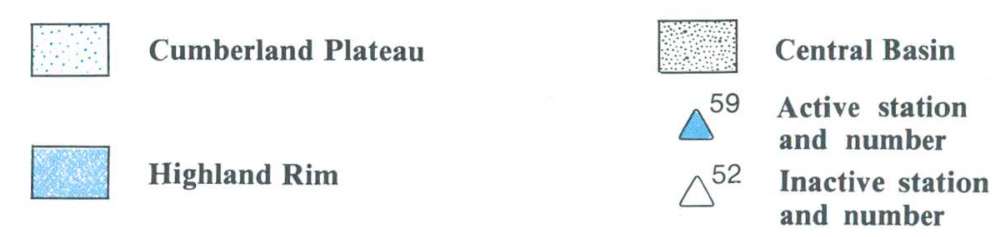

Figure 5.1-1 Physiographic regions and location of gaging stations

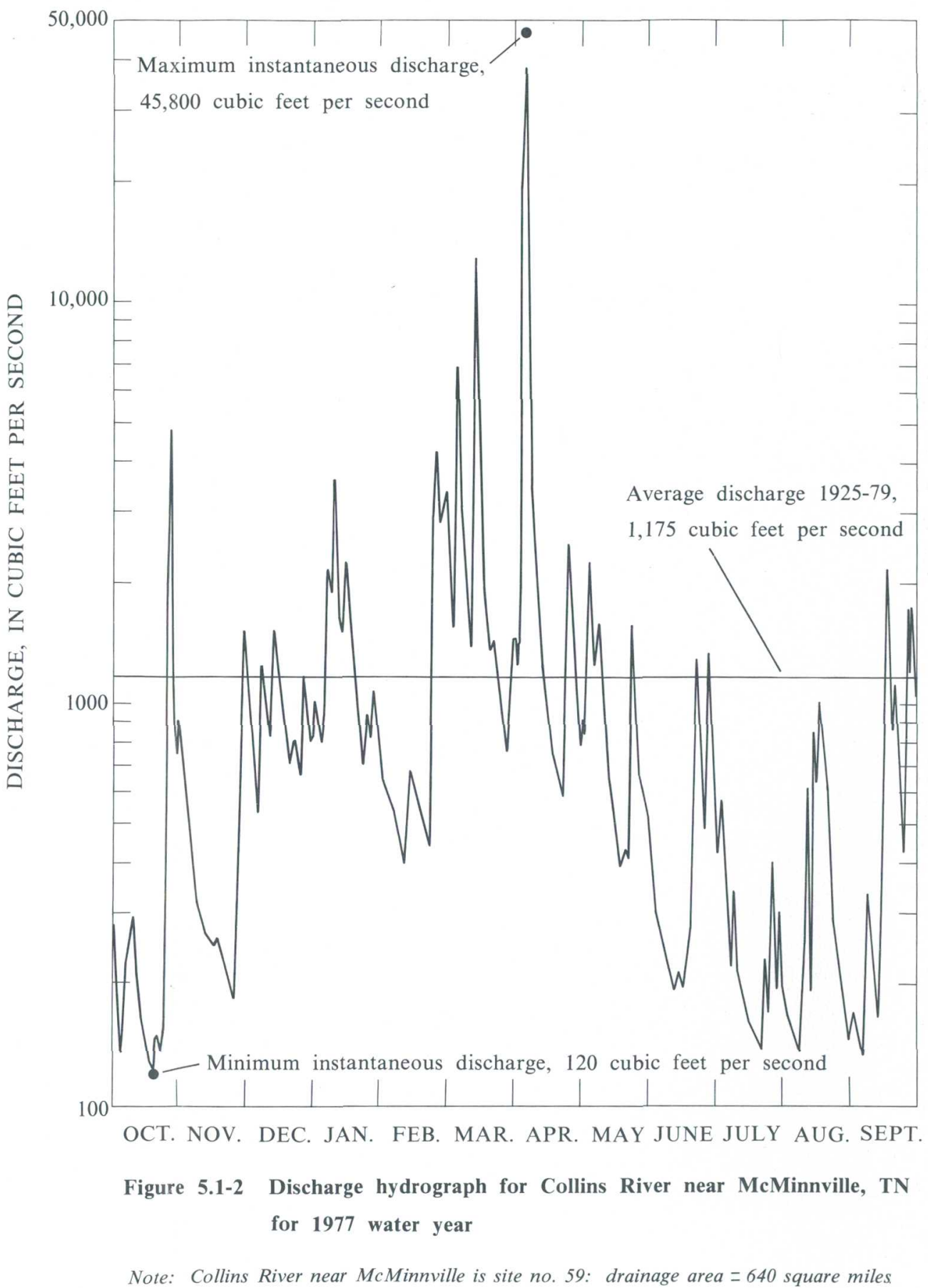

Table 5.1-1 Percentage of annual mean discharge occurring in indicated month

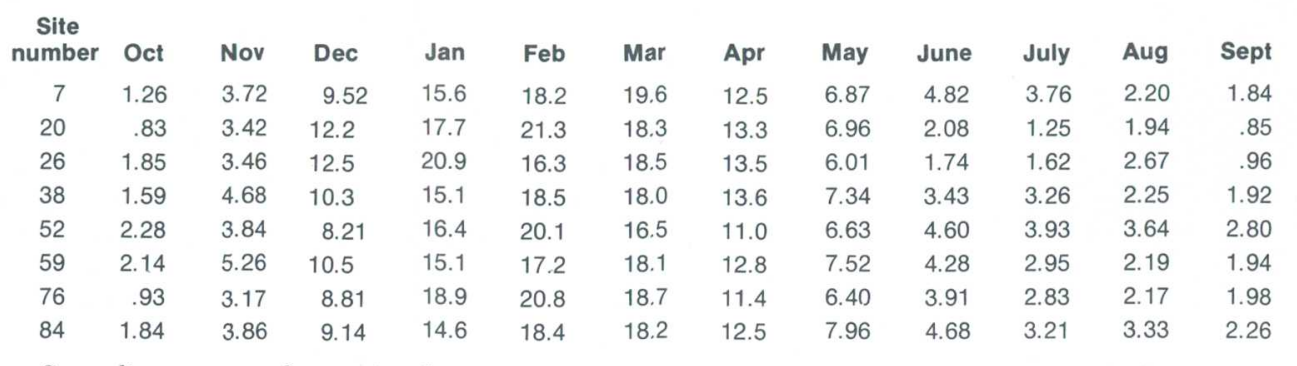

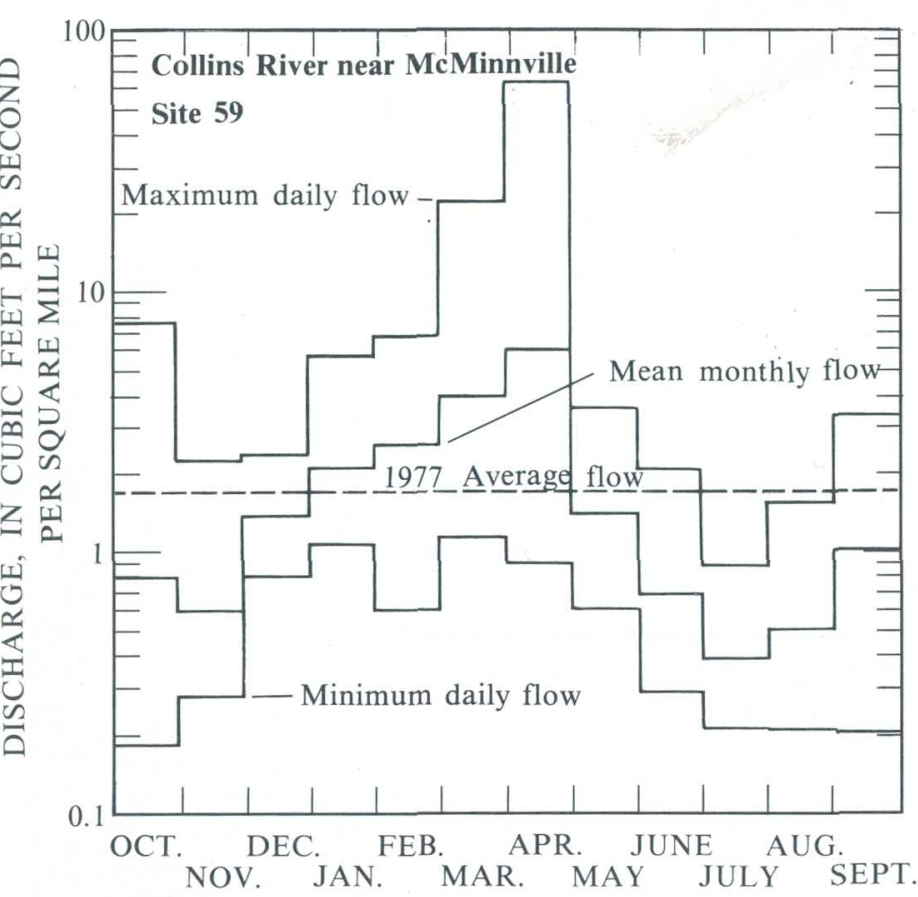

Figure 5.1-3 Mean monthly and maximum and minimum daily flow for the 1977 water year

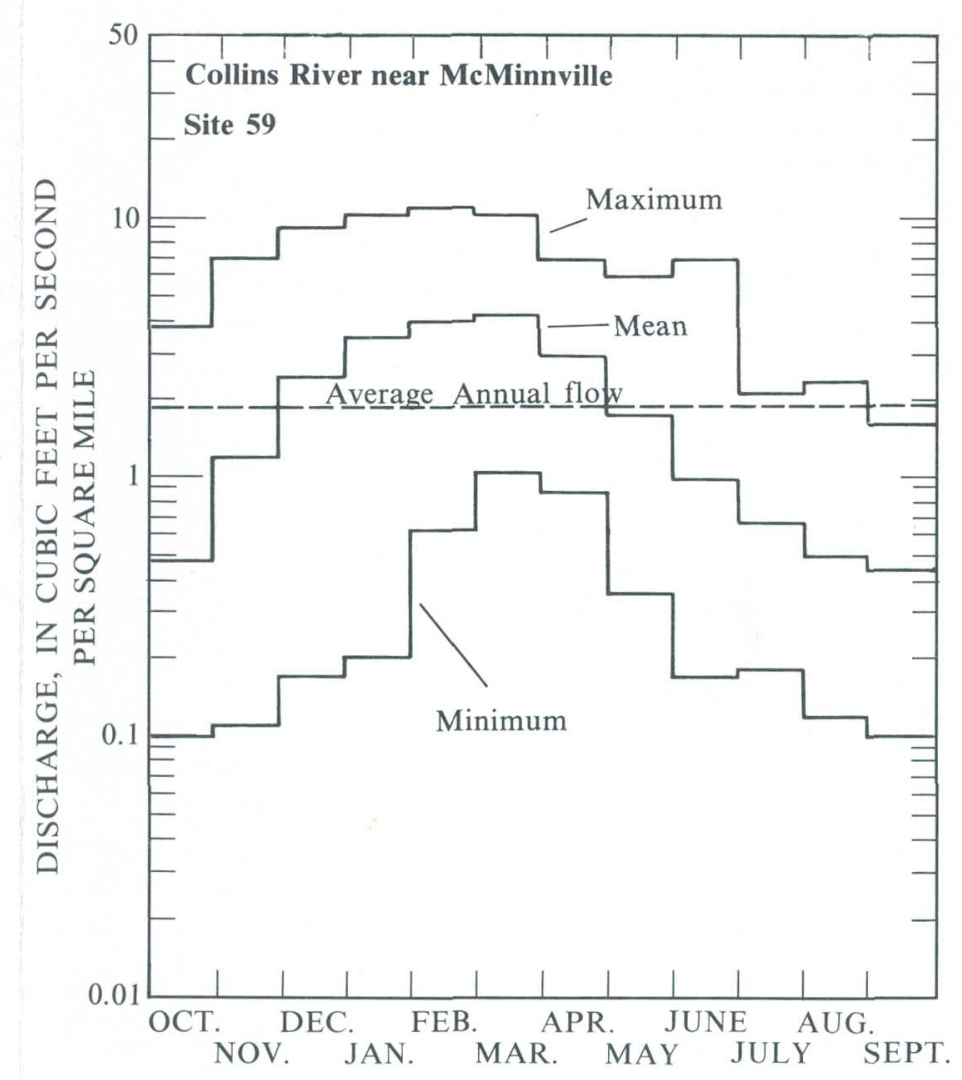

Figure 51-4 Average annual and range in monthly mean flow per square mile for the period $1925-79$ 


\title{
5.0 SURFACE WATER (Continued) \\ 5.2 Average Flow
}

\section{AVERAGE FLOW PER SQUARE MILE IS FAIRLY UNIFORM}

\author{
The seasonal variability of the mean and maximum monthly flows \\ per square mile is similar throughout Area 18; however, the \\ minimum monthly flow per square mile is low for the Cumberland \\ Plateau region.
}

The average annual flow of streams may be useful in some hydrologic studies but for most purposes average monthly flow is more useful. Assuming the same annual precipitation, the principle factor affecting average annual flow is the size of the drainage basin. In addition to drainage basin size, seasonal variations in rainfall affect mean monthly flows. If the maximum and minimum monthly flows are analyzed, variations due to other factors can be detected, the prominent one being that the underlying geology affects the minimum monthly flow, especially during the dry months.

The average annual flow and the minimum, mean and maximum monthly flow plotted in unit discharge (cubic feet per second per square mile) are shown for several streams in figure 5.2-1. The use of unit discharge eliminates the variation due to size of the drainage basin so that more direct comparison between streams may be made. The average annual flow per square mile is approximately the same for all stations. The seasonal variability of the mean and maximum monthly flows per square mile is similar even with the varying lengths of available record. Those streams on the Cumberland Plateau, however, show much lower minimum monthly flows per square mile for the dry months than do streams in the other two physiographic regions. This indicates that these streams do not sustain flow well during periods of no rainfall which is a result of either poor infiltration qualities of the land surface or the poor ability of the underground aquifer systems to store water, or both. 


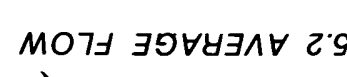

(pənu!nuo)) \&GLVM GOV.A8กS 0.S

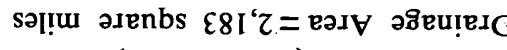

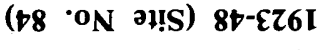

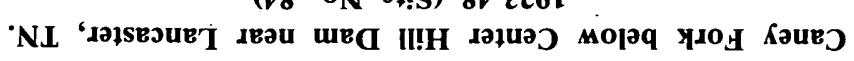

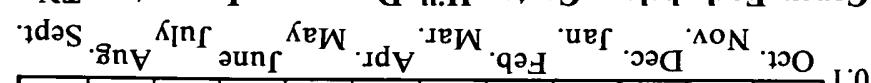

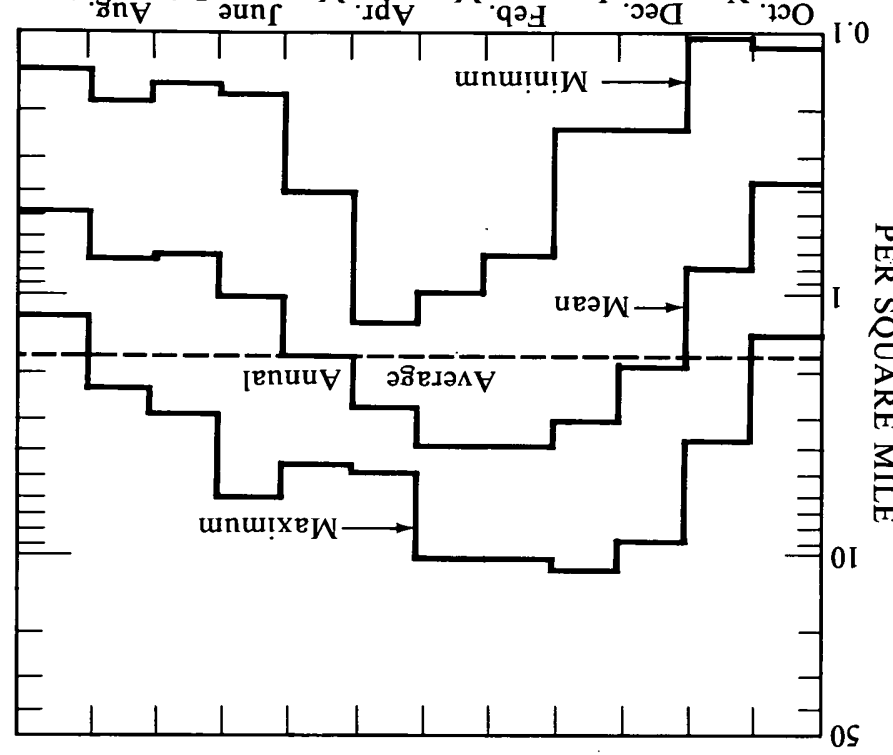

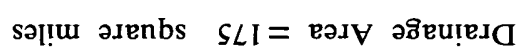

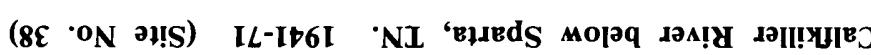

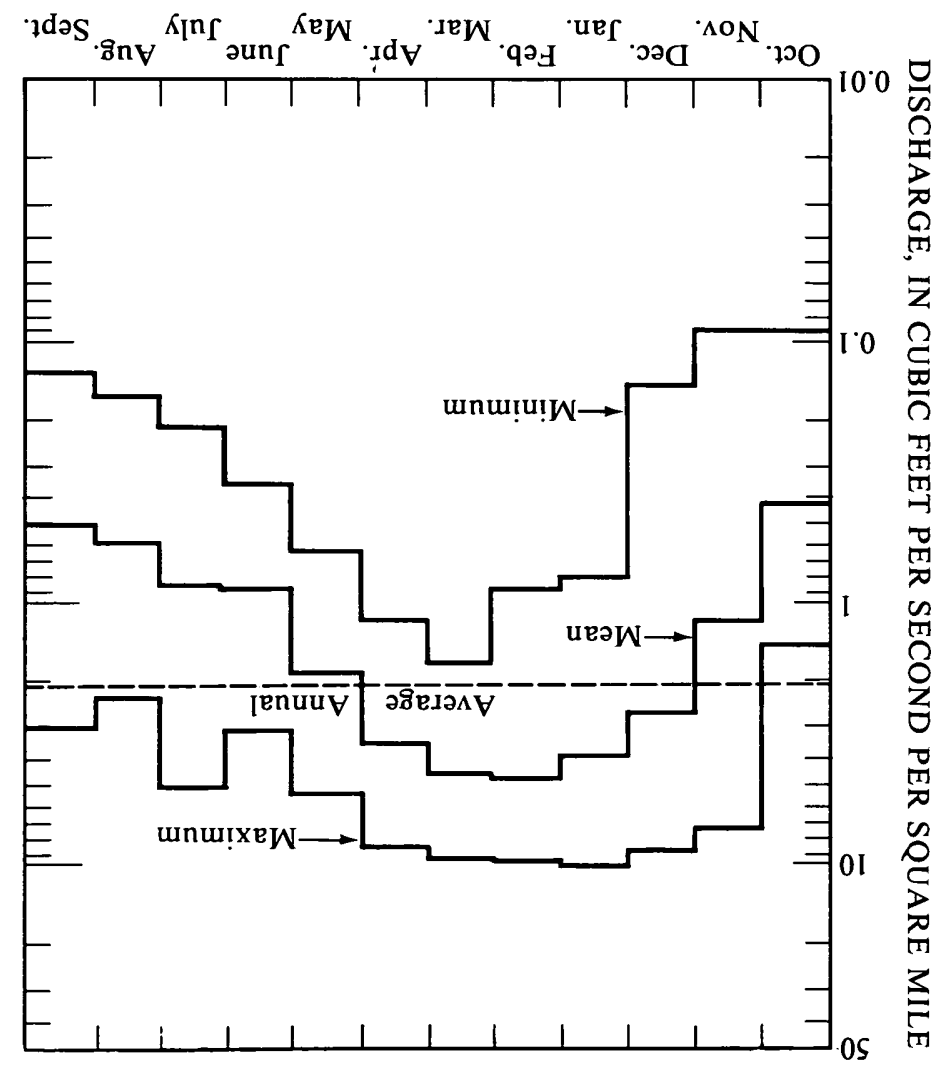

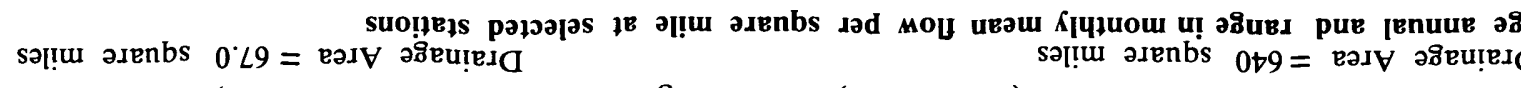

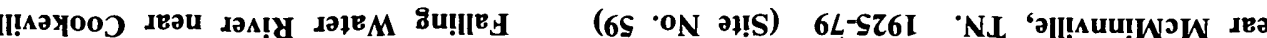
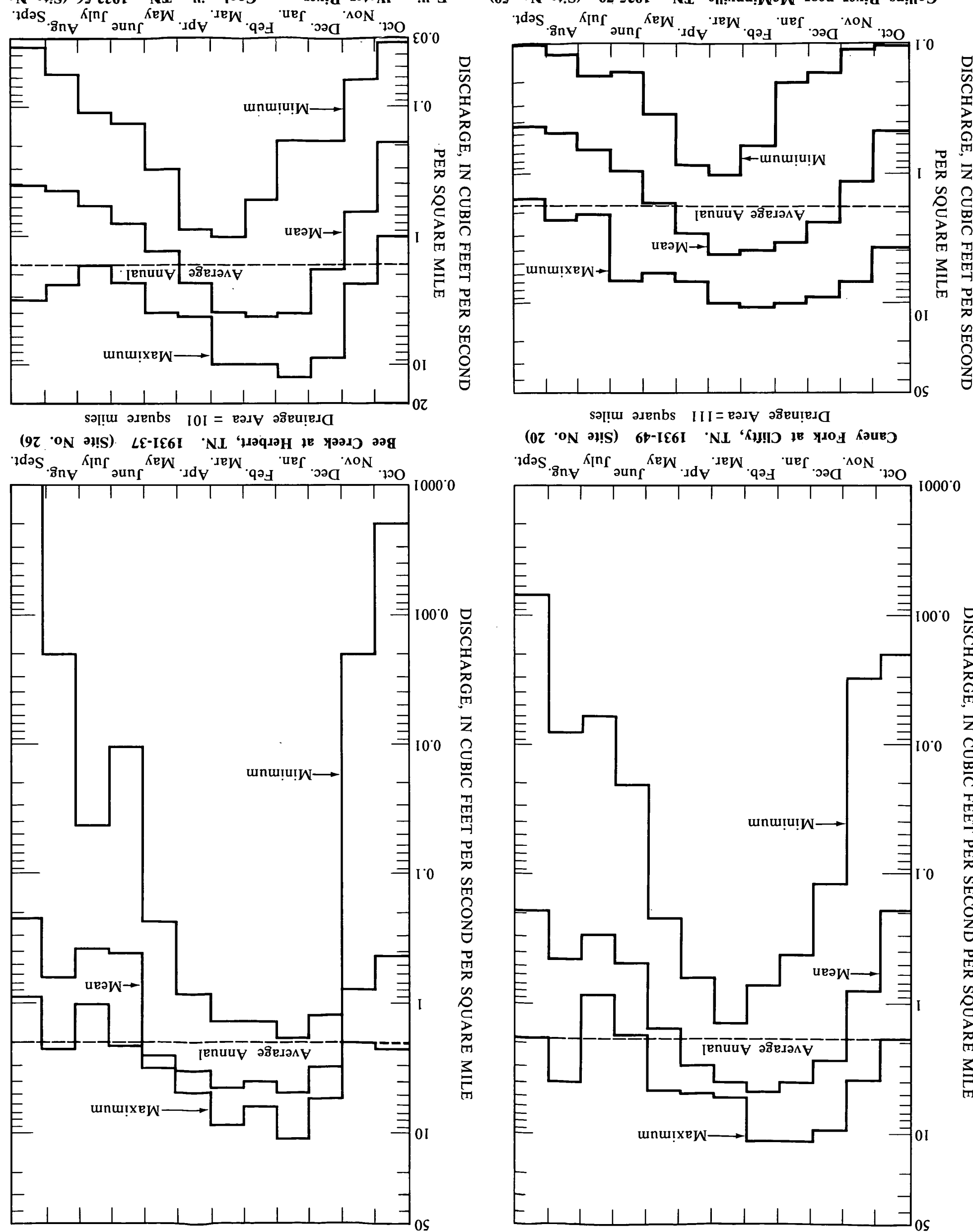

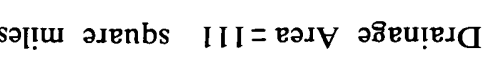

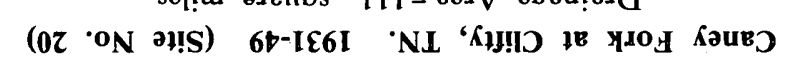

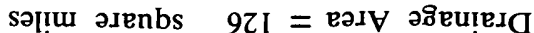

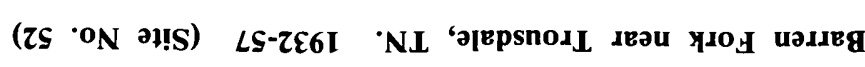

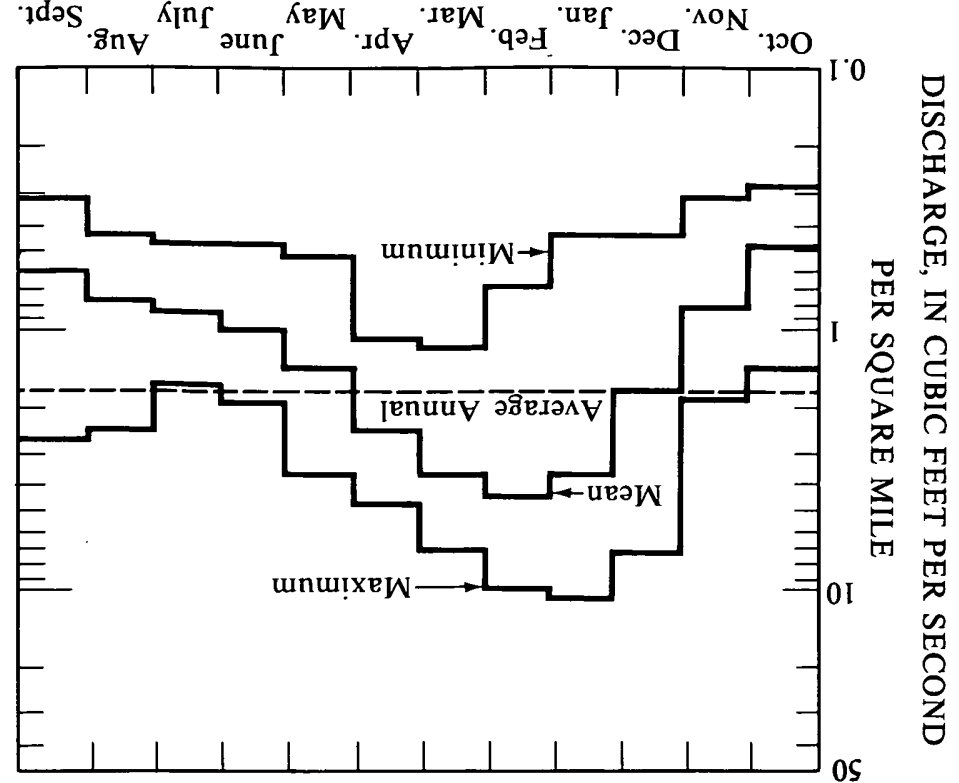

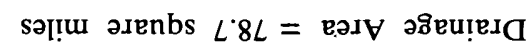

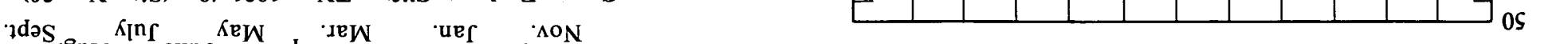

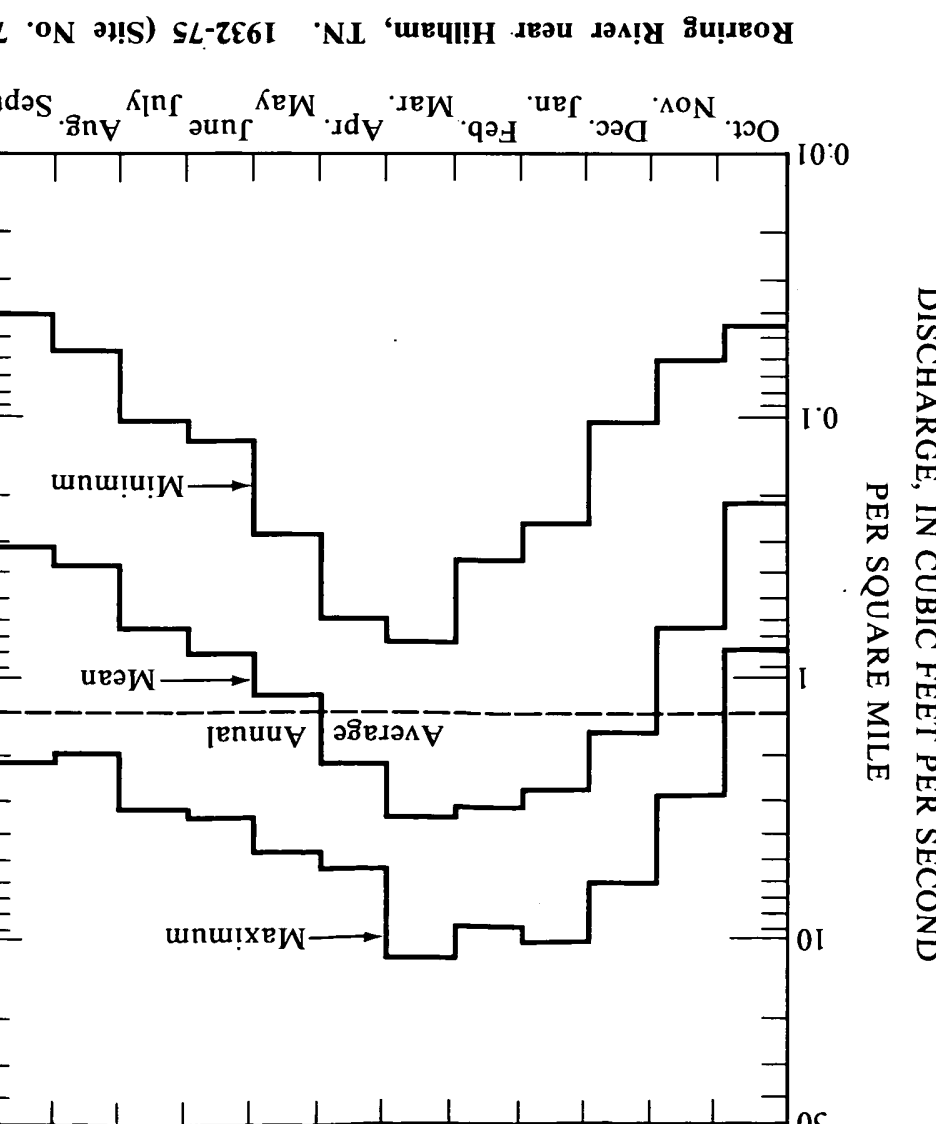




\title{
5.0 SURFACE WATER (Continued) \\ 5.3 Low Flow
}

\section{CUMBERLAND PLATEAU STREAMS HAVE POOR YIELDS DURING LOW FLOW}

\author{
The 3-day, 20-year and the 7-day, 10-year recurrence interval \\ low flows are lower for Cumberland Plateau streams than elsewhere \\ in Area 18.
}

The low-flow characteristics of an entire region are difficult to define because they are not readily susceptible to regionalization. This is due to the fact that the low flow of streams is affected by several factors which are difficult to measure quantitatively, such as the geology of the area, the perviousness of the soil, the type and density of vegetation, and others.

Probably the most valuable data for low-flow purposes are continuous record gaging station data from which low-flow frequency curves can be derived. Low-flow frequency is expressed as the lowest flow for a given number of consecutive days for a given recurrence interval, or average return period. A common index of low flow is the average 3-day, 20 -year recurrence interval flow. A generalized view of this low flow index for selected streams in Area 18 is shown in figure 5.3-1. The 3-day, 20-year flow is shown as a discharge range that is applicable to a reach of stream. The low flows of streams on the Cumberland Plateau are generally lower than for streams elsewhere.

Another common index of low flow is the 7-day, 10 -year recurrence interval flow. There is probably no exact relationship between the two indices but the 7-day, 10-year recurrence interval flow is generally larger than the 3-day, 20-year recurrence interval flow by about 20 percent. The two low-flow indices are shown for several stations in Area 18 in table 5.3-1 (Gold, 1980). The locations of these stations are shown in figure 5.3-1. 


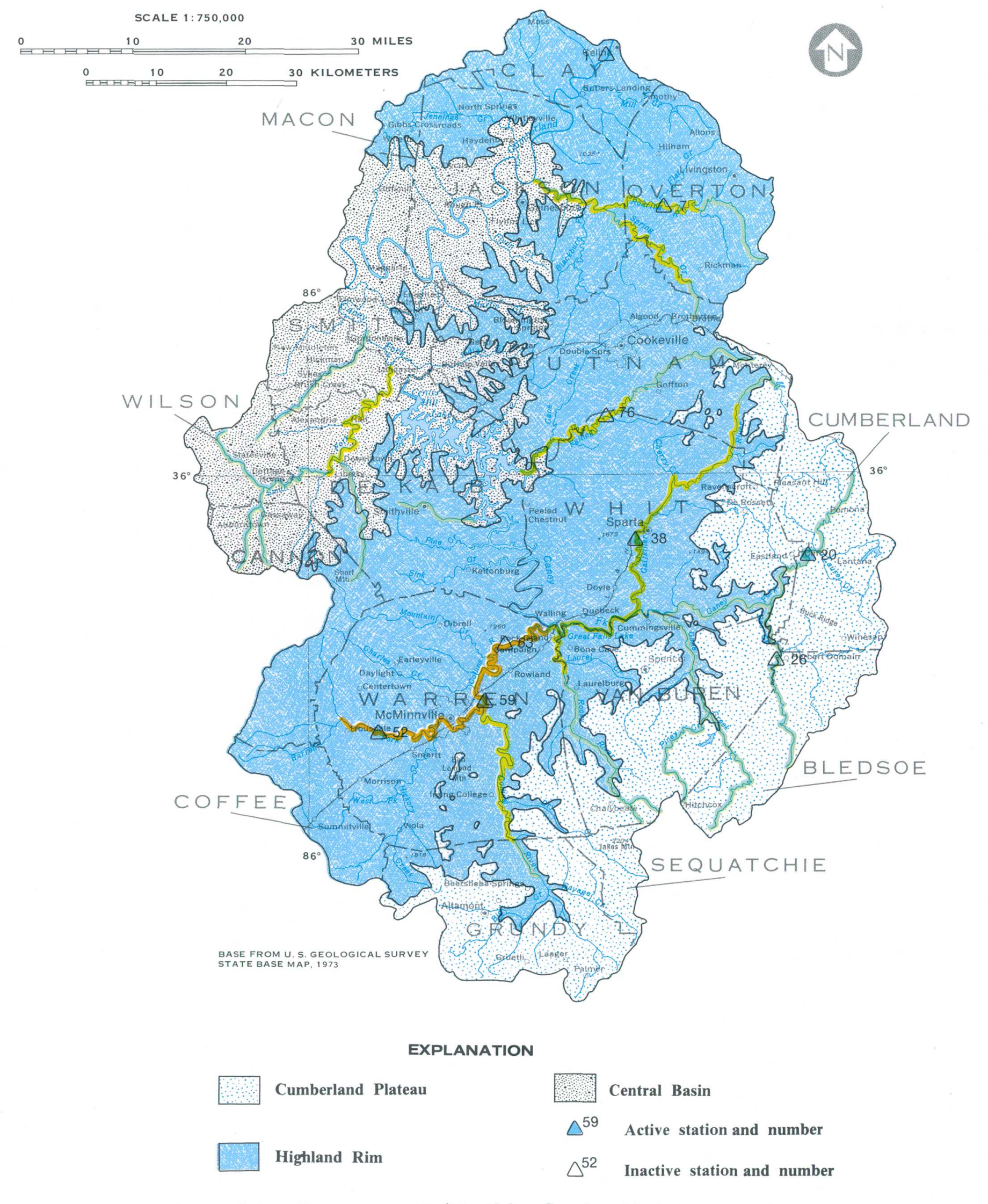

Site Number

Station Name

Cumberland River at Celina
(unregulated period)

Roaring River near Hilham

Caney Fork at Clifty

Bee Creek at Herbert

Calfkiller River below Sparta

Barren Fork near Trousdale

Collins River near McMinnville

Collins River near Roland

Falling Water River near Cookeville
3-Day, 20-Year

Interval Flow $\left(\mathrm{ft}^{3} / \mathrm{s}\right)$

3.28

0

0

14.2

34.4

48.6

59

2.09
7-Day, 10-Year

Interval Flow $\left(\mathrm{ft}^{3} / \mathrm{s}\right.$ )

Average 3-day, 20-year recurrence interval low flow in cubic feet per second:

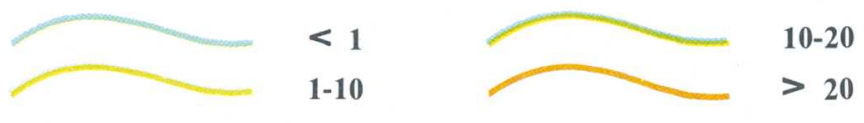




\title{
5.0 SURFACE WATER (Continued) \\ 5.4 Floods \\ 5.4.1 Magnitude and Seasonal Distribution of Floods
}

\section{MAXIMUM KNOWN FLOODS RELATED TO DRAINAGE AREA}

\author{
Most floods occur in the winter and spring. The magnitude \\ of past floods and size of drainage basin are related.
}

\begin{abstract}
A considerable amount of flood data is available in Area 18. This includes the magnitude of peak discharges for many observed floods on streams within the area. The maximum known flood at a site is related to the size of that drainage basin as shown in figure 5.4.1-1. Also shown on figure 5.4.1-1 is the relationship between maximum known floods and the 50 -year flood. This plot includes maximum observed floods at gaging stations and extreme floods that have been measured at miscellaneous sites on a nonsystematic basis. The occurrence of floods is a natural, random phenomenon, and higher floods than those observed can occur at any time.
\end{abstract}

An analysis of the flood data collected in Area 18 indicates some seasonal flood trends which may be useful (fig. 5.4.1-2). On streams draining basins larger than $10 \mathrm{mi}^{2}$, almost 65 percent of the annual peaks occur during the period January through March and about 87 percent occur during the period December through April. On streams draining basins smaller than $10 \mathrm{mi}^{2}$, more than 25 percent of the annual peaks occur in March with the remainder being more evenly distributed throughout the rest of the year. By examination of these graphs, it is evident that the winter and spring months account for most of the annual peaks on large streams while on small streams the annual peak has a more equal chance of occurring in any month of the year. 


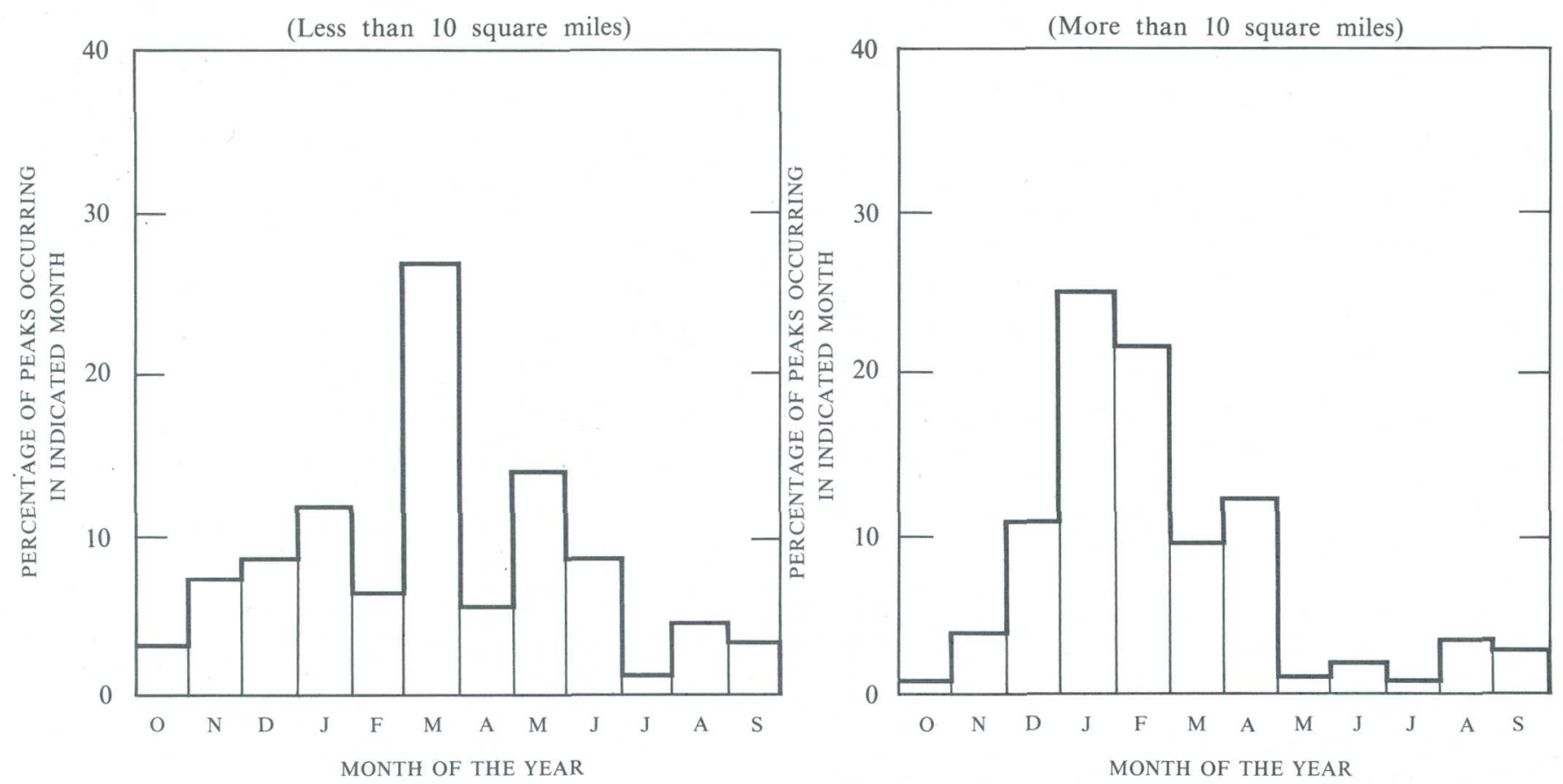

Figure 5.4.1-2 Seasonal distribution of floods.

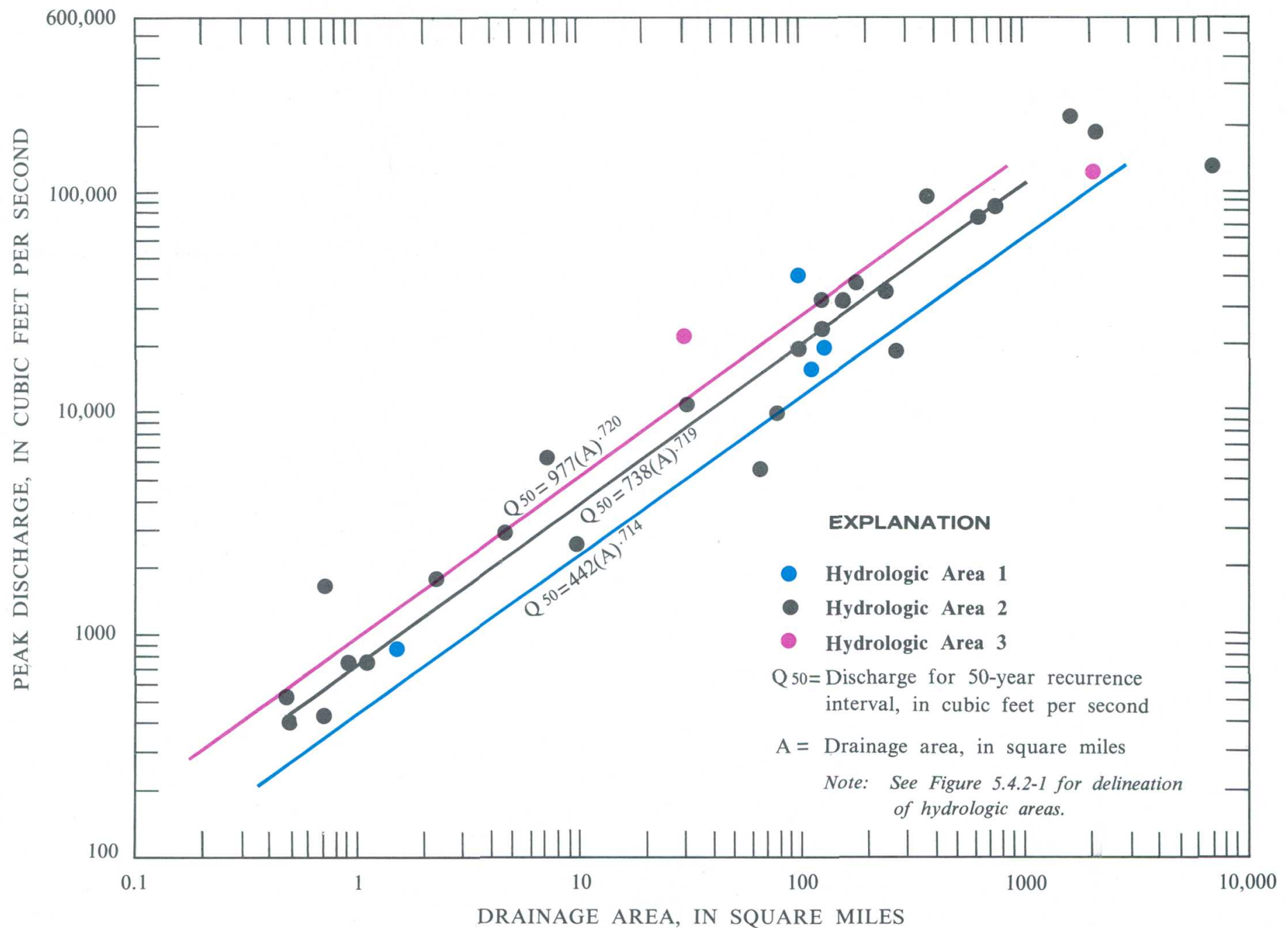

Figure 5.4.1-1 Relation of maximum known and 50-year frequency floods to drainage area

5.0 SURFACE WATER (Continued)

5.4 FLOODS 


\subsection{SURFACE WATER (Continued) \\ 5.4 Floods (Continued) \\ 5.4.2 Frequency of Floods}

\section{MAGNITUDE AND FREQUENCY OF FLOODS ARE RELATED TO DRAINAGE BASIN SIZE}

\section{Equations relating discharge to drainage area for floods of selected frequencies are defined for three hydrologic areas in Area 18.}

Flood-frequency characteristics of natural streams in Tennessee have been defined by Randolph and Gamble (1976). All gaging station records of 10 or more years in length and not significantly affected by manmade changes were analyzed. The State was divided into four hydrologic areas which have distinct flood-frequency characteristics. Area 18 encompasses portions of three of these hydrologic areas as shown on figure 5.4.2-1. The equations for computing discharges for various recurrence intervals for each of these areas as developed by Randolph and Gamble are also shown. Recurrence inter$\mathrm{val}$ is the average interval of time, in years, within which the given flood magnitude will be equaled or exceeded once. Relations are not defined for drainage areas greater or smaller than the ranges shown on figure 5.4.2-1. Techniques for estimating frequency of floods on streams crossing hydrologic area lines are described by Randolph and Gamble (1976, p. 22).

In general, the magnitude of the discharge for a given recurrence interval and drainage area increases from east to west. That is, area 3 produces higher discharges than area 1 for a given frequency and drainage area. For example, for a drainage area of $50 \mathrm{mi}^{2}$ in hydrologic area 1 , the 100 -year flood discharge would be $8,390 \mathrm{ft}^{3} / \mathrm{s}$; in hydrologic area 2 , $14,400 \mathrm{ft}^{3} / \mathrm{s}$; and in hydrologic area $3,18,700 \mathrm{ft}^{3} / \mathrm{s}$. These differences are undoubtedly caused by a combination of many factors, some of which were investigated by Randolph and Gamble. The dominant factors are probably soil types and geology which are not readily susceptible to mathematical analysis because they are difficult to quantify numerically. 


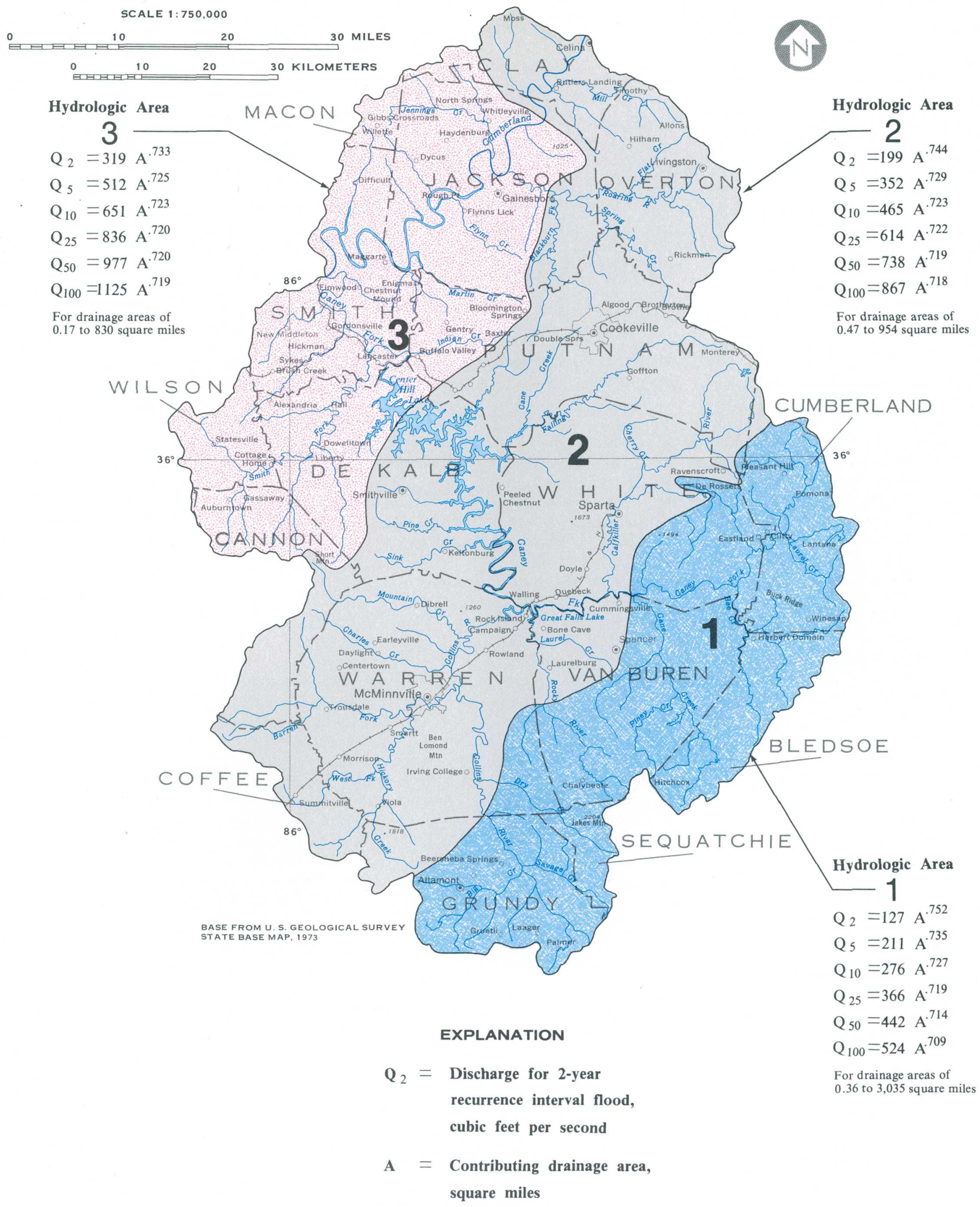

Figure 5.4.2-1 Hydrologic areas and appropriate equations for estimating discharge of indicated frequency

5.0 SURFACE WATER (Continued)

5.4 FLOODS (Continued)

5.4.2 FREQUENCY OF FLOODS 


\title{
5.0 SURFACE WATER (Continued) \\ 5.4 Floods (Continued) \\ 5.4.3 Flood Depths and Flood-Prone Areas
}

\section{METHOD OF PREDICTING 100-YEAR FLOOD DEPTHS AVAILABLE}

\author{
Depths for 100-year flood are predictable. Flood-prone \\ area maps are available for selected areas.
}

The National Flood Insurance Act of 1968 and the Flood Disaster Protection Act of 1973 established programs for identifying towns and streams subject to flood problems and for outlining flood-prone areas on topographic maps by approximate methods. In 1968 the Geological Survey began delineating flood-prone areas of the maximum known flood on 71/2-minute topographic quadrangle maps using existing information. After two years it was decided that areal uniformity of the flood delineated would be desirable, so the 100-year flood was selected for mapping in 1970. A method of estimating the depth (feet) of the 100-year flood on small streams, where little information is available, was needed. Gamble and Lewis (1977) divided the state into four areas and related depth of the 100-year flood to drainage basin size in each of these areas.

Area 18 encompasses parts of two of these areas as shown on figure 5.4.3-1. The equation for computing the depth for each area is shown along with the drainage area size range limitation which applies. This depth-drainage area relation was used in the flood-prone area map delineation program to determine 100-year flood depths, where no other data were available. It can be used to estimate the depth of the 100-year flood for any purpose where extreme accuracy is not necessary.

Flood-prone area maps within or partially within Area 18 are indicated by shading on figure 5.4.3-1, which also shows the names and locations of all $71 / 2$-minute topographic quadrangle maps in the area.

Copies of the flood-prone area maps may be obtained from:

U.S. Geological Survey

Water Resources Division

A-413 Federal Building - U.S. Courthouse

Nashville, TN 37203

Copies of $71 / 2$-minute topographic maps may be purchased from:

Tennessee Department of Conservation

Division of Geology

G-5 State Office Building

Nashville, TN 37219 


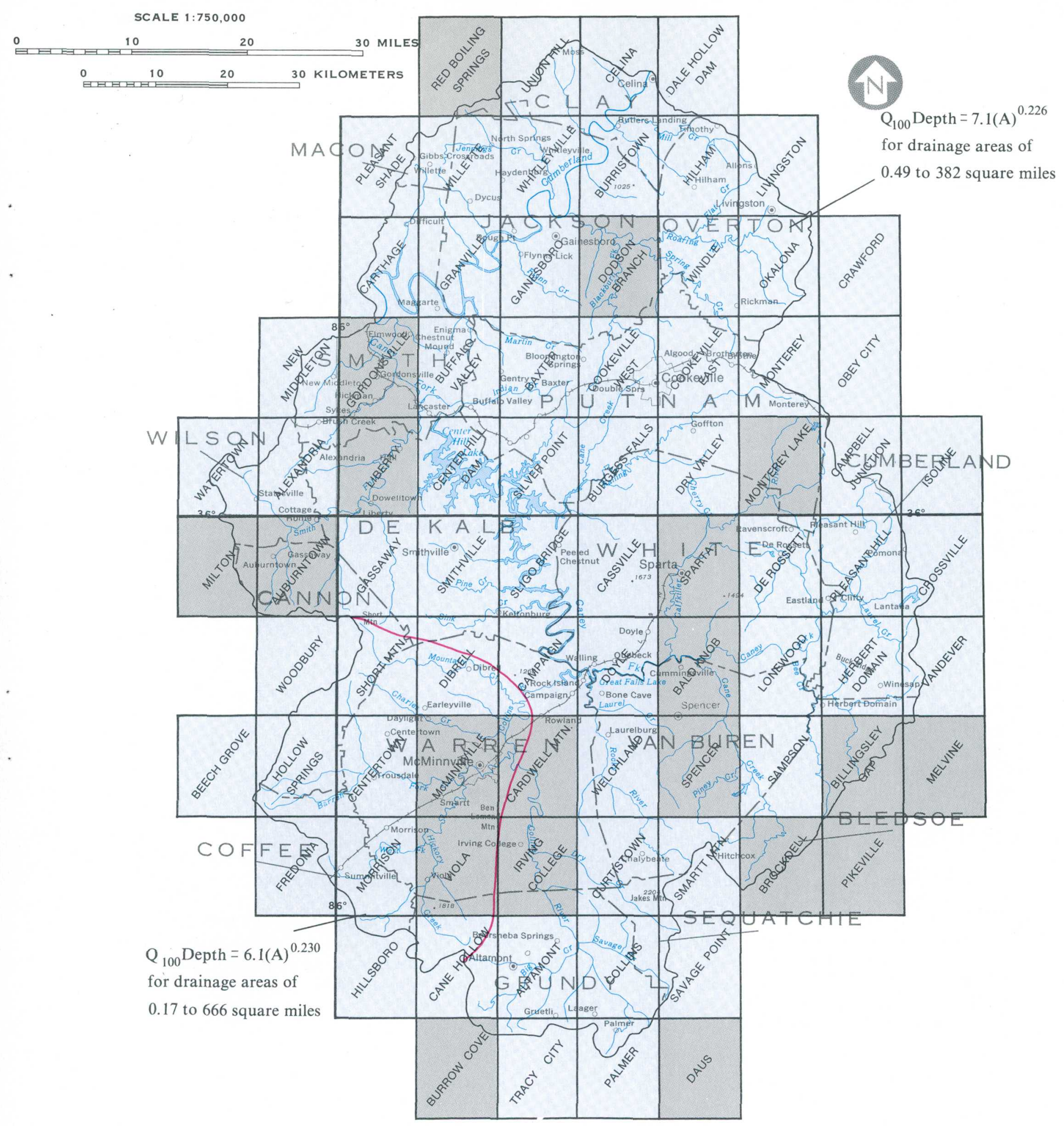

EXPLANATION

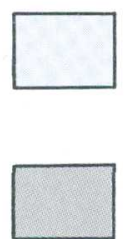

$71 / 2$ minute topographic map

Flood-prone area map

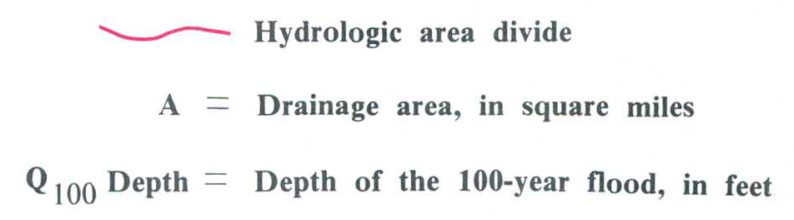

Figure 5.4.3-1 Hydrologic areas with equations for estimating 100-year flood depths, and location of flood-prone area maps and topographic maps

5.0 SURFACE WATER (Continued)

5.4 FLOODS (Continued) 


\title{
5.0 SURFACE WATER (Continued) \\ 5.5 Flow Duration
}

\section{STREAMS DRAINING COAL RESOURCES AREA ARE POORLY SUSTAINED}

\author{
Flow-duration curves indicate streams in the coal resources area \\ do not sustain low flows as well as streams located elsewhere \\ in Area 18.
}

The water flowing in a stream past a given point, such as a gaging station, is the surface outflow of the drainage basin above the specified point. Thus, the streamflow record is an integration of the effects of climate, topography, and geology, and gives a distribution of runoff both in time and in magnitude. If the flows are arranged according to frequency of occurrence and plotted as a flow-duration curve, the resulting curve shows the integrated effect of the various factors that affect runoff in that basin. Thus, flow-duration curves provide a convenient means of comparing the flow characteristics of one stream, or basin, with another and of determining the probability of future flow magnitudes.

The slope of the flow-duration curve for a stream is a measure of that stream's variability of flow. A steep slope indicates highly variable flow whereas a flat slope indicates a more uniform flow which tends to be equalized by surface-or ground-water storage.

Differences in streamflow for three stations in Area 18 are illustrated by flow-duration curves (fig. 5.5-1). Flow-duration data for other streams in Area 18 may be found in Gold (1980). These curves are based on varying periods of record for each station but are plotted in unit discharge (cubic feet per second per square mile) so that more direct comparison may be made. The streams selected are located in two of the physiographic regions of Area 18. There are no streams in the Nashville Basin part of Area 18 for which long-term continuous records have been collected. However, flow-duration curves for streams located just outside Area 18 indicate similar flow characteristics to those on the Highland Rim (see Section 2.2). The curve for Caney Fork at Clifty represents the Cumberland Plateau and is rather steep on the lower two-thirds of the curve indicating the poor recharge and/or storage qualities of the ground water system of that region which results in poor yields during dry periods. The curves for Calfkiller River below Sparta and Roaring River near Hilham have flatter slopes on the lower end indicating better yields of the ground-water system of the Highland Rim and probably of the Nashville Basin.

The upper end of all three curves has essentially the same slope and they are positioned very close together indicating that the high-flow runoff per square mile from all three physiographic regions is nearly the same. 


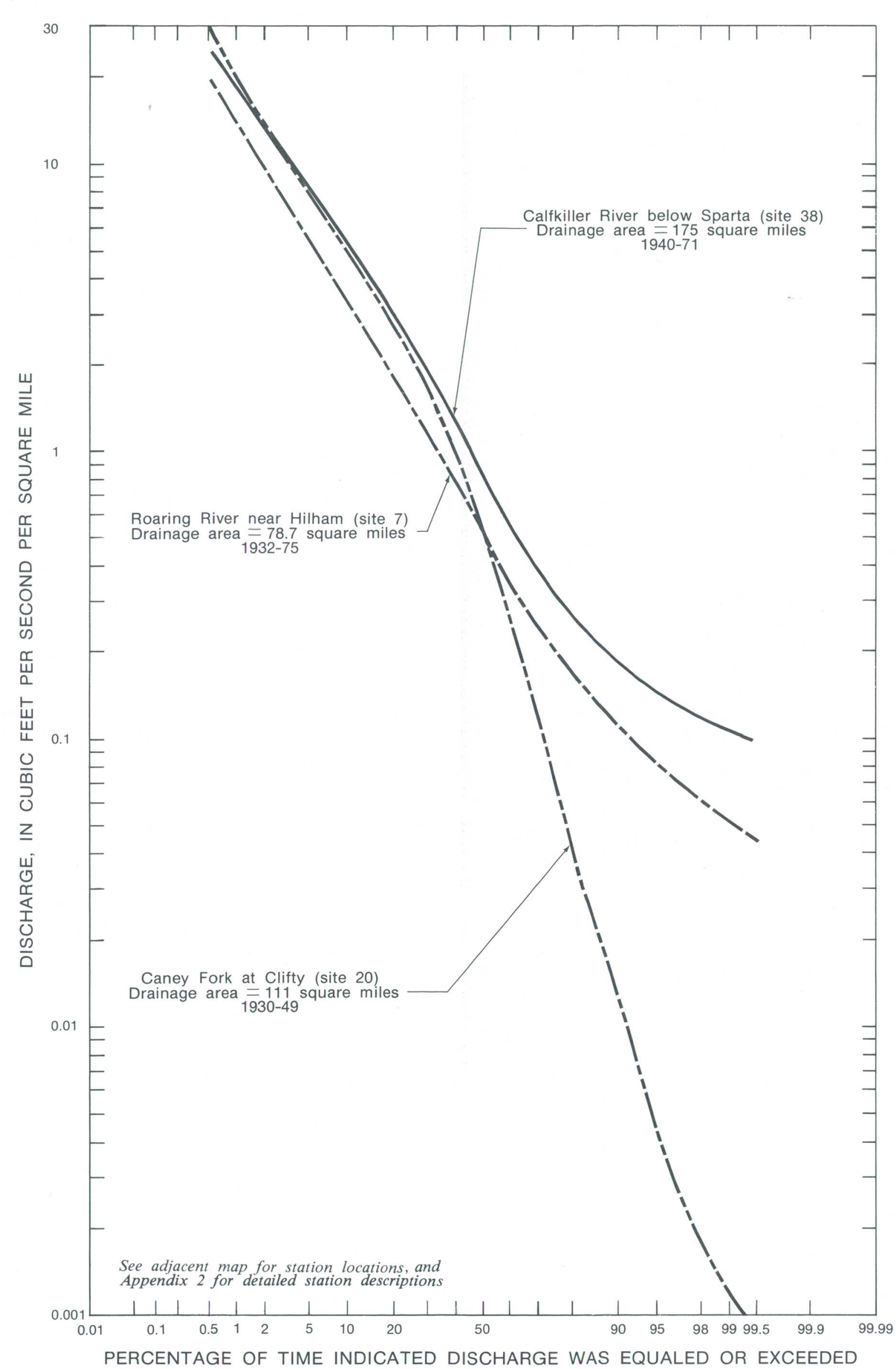

PERCENTAGE OF TIME INDICATED DISCHARGE WAS EQUALED OR EXCEEDED

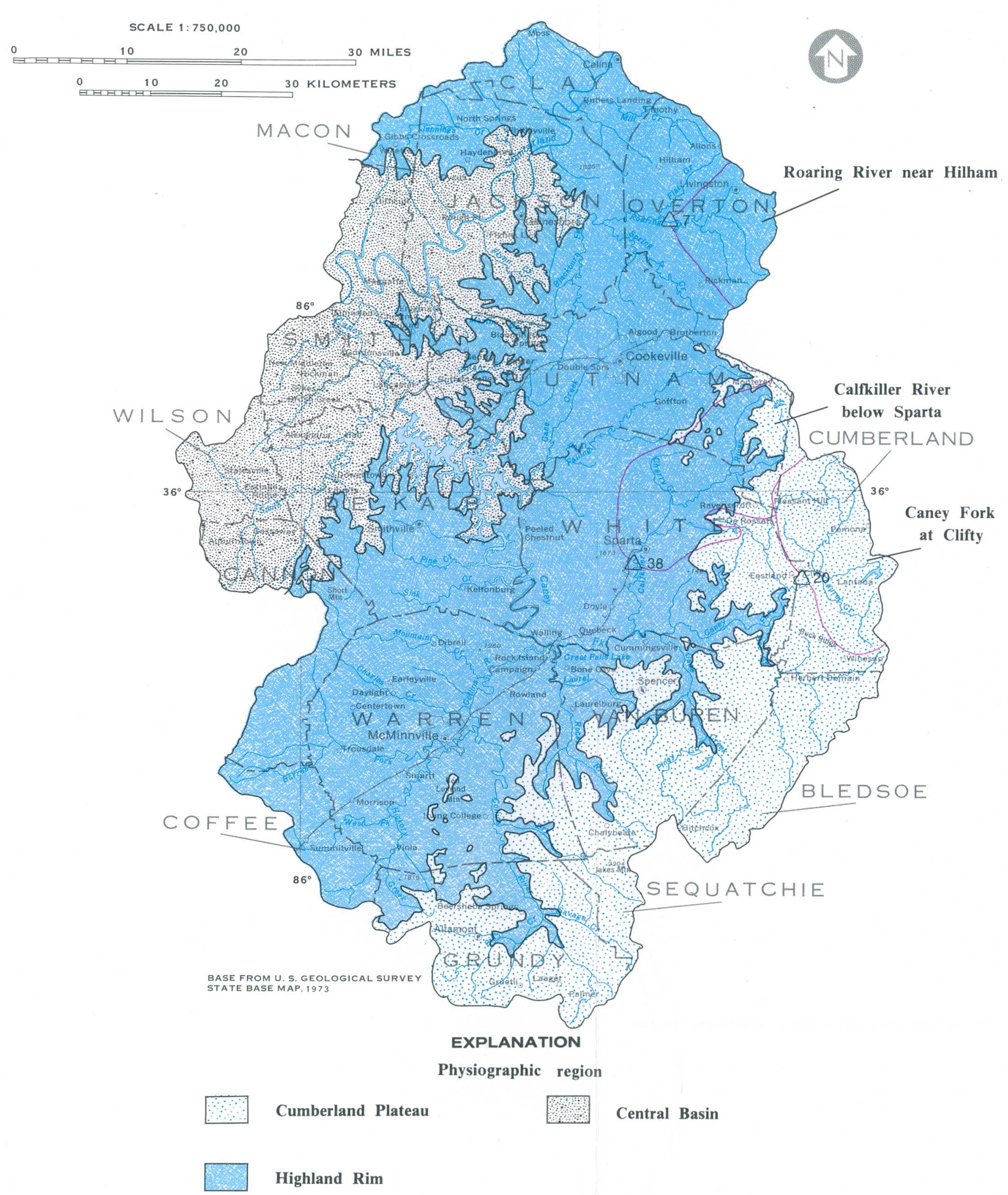

Figure 5.5-2 Location of basins for which flow duration curves are shown 


\title{
GROUND WATER OCCURS IN THREE DISTINCTIVE AQUIFER SYSTEMS CORRESPONDING TO THE THREE PHYSIOGRAPHIC REGIONS
}

\author{
The aquifer systems in Area 18 include the fractured sandstones and \\ conglomerates beneath the Cumberland Plateau, the carbonate rocks \\ (limestone and dolomite) and overlying thick regolith (weathered rock \\ and soil) beneath the Highland Rim; and the limestones beneath \\ the Central Basin.
}

The major aquifers in the Cumberland Plateau, are formed by essentially flat lying sandstones and conglomerates. These aquifers are separated by interbedded shales and coals which act as local confining beds (fig. 6.1-1). Although some of the sandstones and conglomerates contain openings in the form of intergranular pores, most of these rocks are firmly cemented, and therefore, are subject to fracturing. It is the fracture system that provides the openings for the storage and transmission of most of the ground water. The fracture system is not homogeneous, however, and the yields of these aquifers to individual wells are highly variable. Many springs occur where the bottoms of the sandstone beds are exposed in ravines marking local discharge points for these aquifers. In most of the Plateau, these aquifers are locally confined and water levels in wells rise above the top of the aquifer. The regolith, which is characteristically thin in this region, provides little ground-water storage.

The major aquifers in the Highland Rim are formed by solution-prone carbonate rocks which have weathered to form a deep regolith at the land surface. Both the regolith and the carbonates are water bearing, but their hydrologic properties are strikingly different. The regolith contains openings in the form of intergranular spaces much like those in a deposit of sand or gravel. In contrast, the underly- ing bedrock transmits water almost exclusively through an anisotropic, nonhomogeneous network of solution openings. The regolith serves as a storage reservoir that slowly provides water to the network of solution openings in the bedrock part of the aquifer. Conditions in the aquifer are generally unconfined, but in some areas clay sized chert particles in the upper part of the regolith create local artesian conditions. Springs are common along the Highland Rim escarpment.

In the Central Basin part of Area 18, ground water occurs in solution enlarged openings developed along joints, fractures, and bedding planes in the limestone bedrock. The relative purity of these limestones and their lack of insoluble material result in a very thin accumulation of residual soil; average thickness is about $\mathbf{4}$ feet. Because the residual soil in this part of the area is thin or absent, it is ineffective as a storage reservoir for ground water. As a result, the occurrence and movement of ground water is entirely dependent on the presence of solution openings, which are most likely to occur within 100 feet below the land surface. Openings are less abundant at greater depths, although reports from drillers indicate some openings have been penetrated in the Central Basin at depths of several hundred feet. 


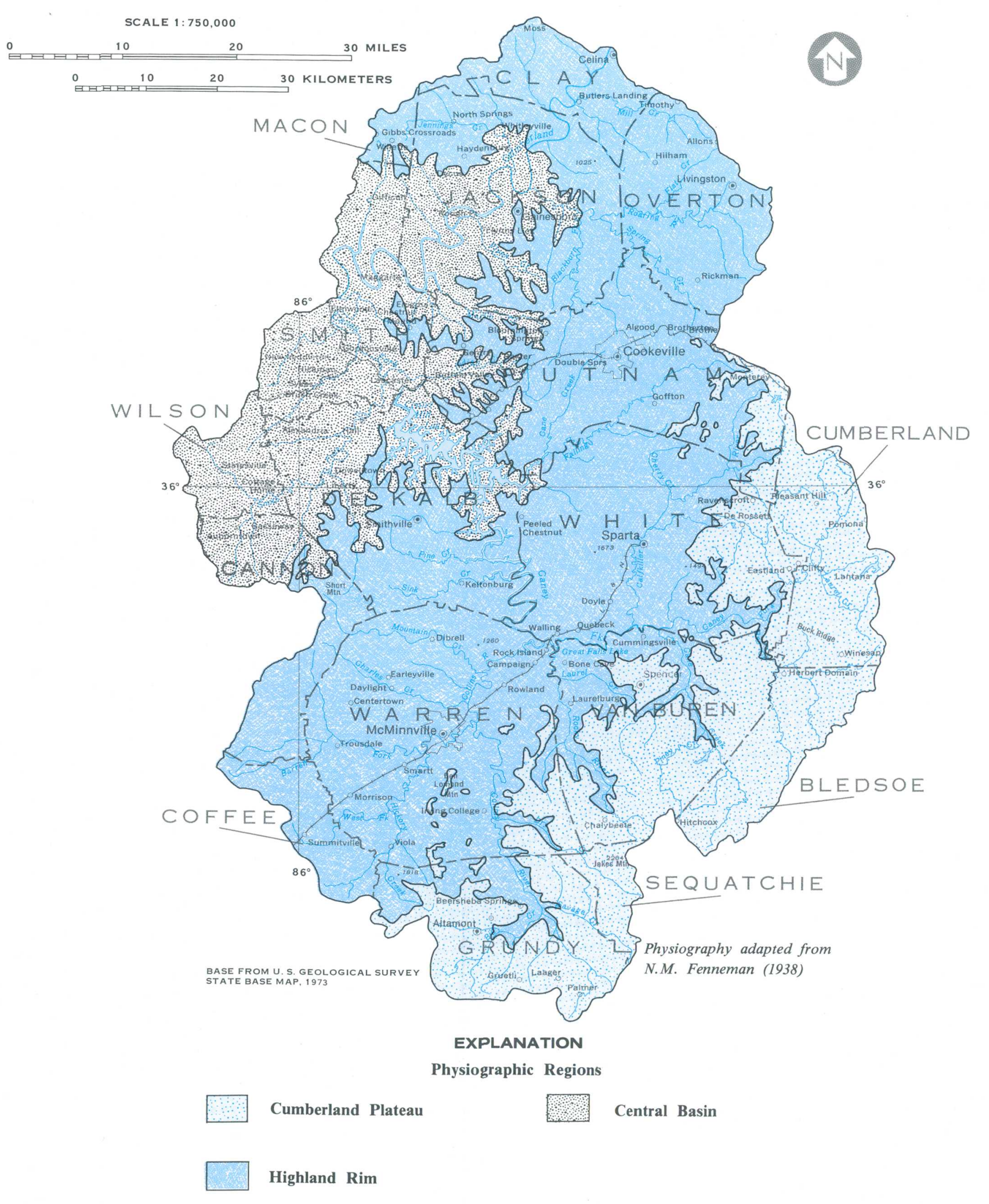

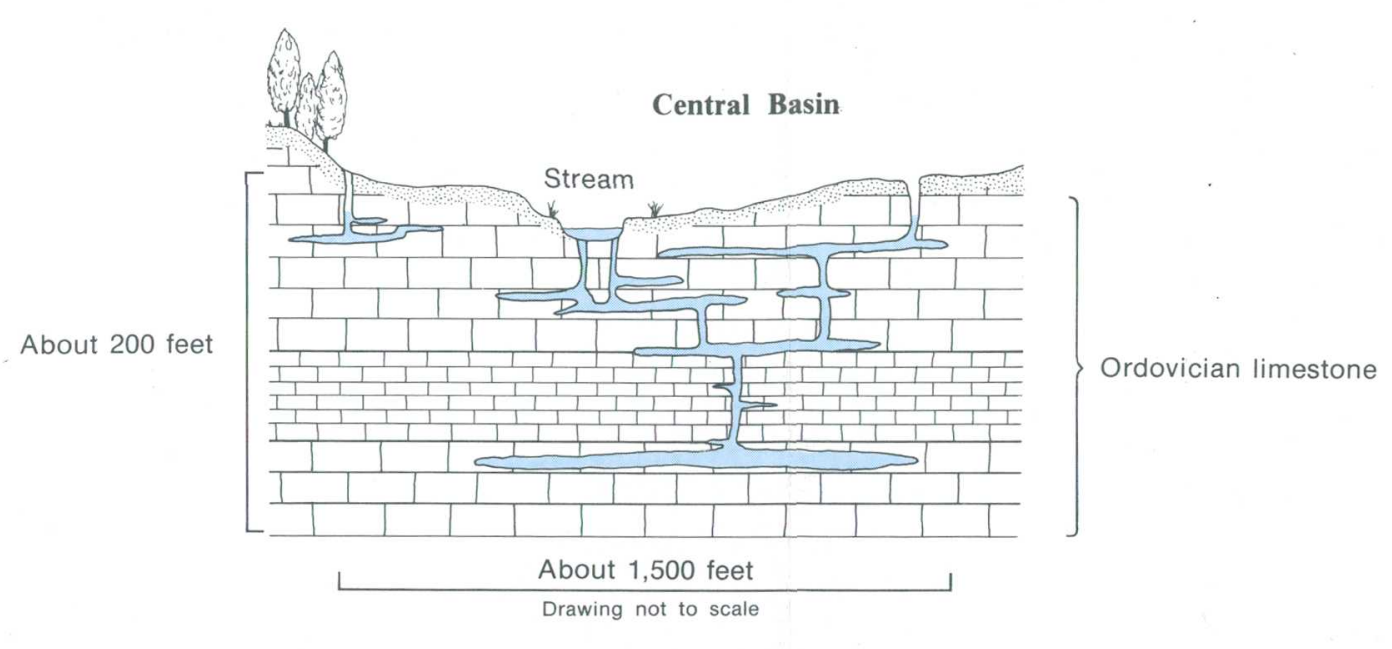
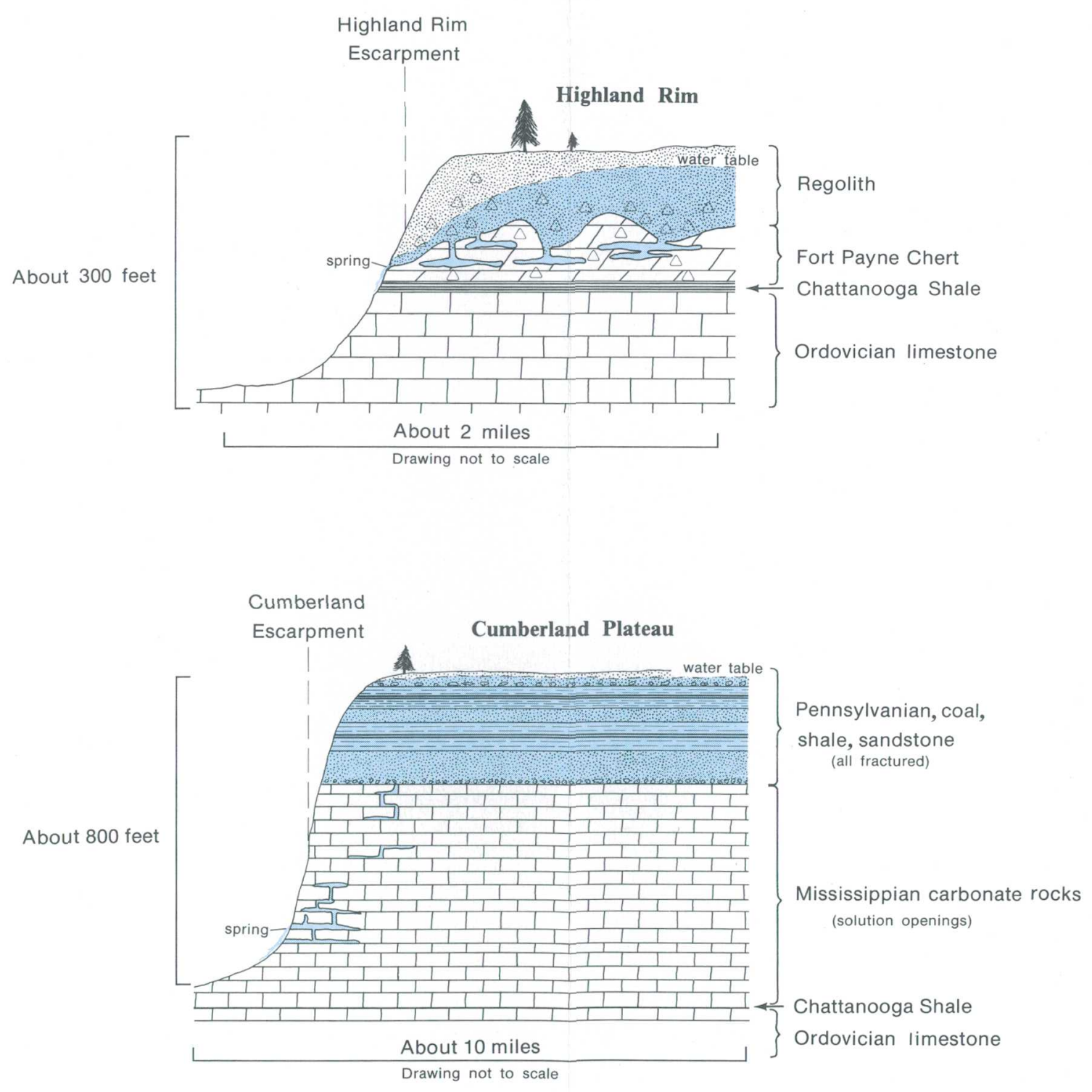

Geology modified from Zurawski (1978) 


\title{
6.0 GROUND WATER (Continued) \\ 6.2 Water Level in Wells
}

\section{GROUND-WATER LEVELS FLUCTUATE FROM SEASON TO SEASON}

\author{
Ground-water levels rise in winter and decline in summer indicating \\ a seasonal change in ground-water storage as a result of relative \\ differences in rates of recharge to and discharge from \\ the subsurface reservoirs.
}

Throughout Area 18, water levels in wells tend to follow a seasonal cycle with highest levels occurring in the spring before the onset of the growing season and lowest levels occurring in the fall just prior to the first killing frost. During the non-growing season, water levels rise in response to a condition in which the rate of recharge exceeds the rate of discharge causing ground-water storage to increase. During the growing season, water levels tend to decline in response to the reverse condition wherein the rate of discharge exceeds the rate of recharge. These seasonal differences in the relative rates of recharge and discharge are due to the impact of evaporation and transpiration losses which are greatest in the warm summer months and least in the cold winter months.

Fluctuations of water levels characteristic of wells in Area 18 are reflected in the observation well hydrographs shown in figure 6.2-1. These hydrographs depict the monthly medians and extremes of the lowest water levels measured near the end of each month for the period of record in each observation well. Differences in the amplitude of the seasonal fluctuations as shown by the median values in the three hydrographs reflect relative differences in the hydrologic properties of the respective aquifers. The smallest amplitude, about 3 feet, occurs in well Pm:C-1 which taps solution openings in the carbonate rocks of Mississippian Age. The other two wells have amplitudes of about 5 and 6 feet. This suggests that the aquifer penetrated by well Pm:C-1 is more porous and permeable than the aquifers penetrated by either of the other two wells.

Differences in the depths to water in these observation wells are due primarily to differences in the topographic settings of the wells. For example, well $\mathrm{Pm}: \mathrm{C}-1$ which is located on a hilltop has the deepest water level of the three wells. In contrast, well
Cn:D-1 which is located at the base of a high hill near a perennial stream has the shallowest water level. The third well, $\mathrm{Cu}: \mathrm{C}-1$, has an intermediate water level due to its location on a low divide at a considerable distance from the nearest stream.

Long term water-level records such as those in figure 6.2-1 can be used as indexes to interpret hydrologic conditions in the general vicinity of the observation wells. For example, current conditions can be inferred by plotting current measurements of water levels in these observation wells, and noting the relative position of the plotted points with respect to the previous recorded medians and extremes. If a measurement plots above the median for the month in which it was made, it indicates that water levels are generally higher than normal in wells in the area represented by the index well. Likewise, if a measurement plots below the median, it indicates that water levels are generally lower than normal. Whatever the inference, it can be applied to waterlevel measurements made in other wells in the general vicinity of the index well. In this way, the significance of infrequent measurements made at or near proposed mine sites can be interpreted in terms of prevailing hydrologic conditions.

Summaries of either monthly or more-frequent water-level measurements for the three index wells shown in figure 6.2-1 are published annually by the U.S. Geological Survey, Nashville, in "Water Resources Data for Tennessee." Water-level measurements for well Pm:C-1 are also released monthly by the Survey in a pamphlet entitled "Water Resources Conditions in Tennessee." Both of these reports can be obtained from the District Chief, U.S. Geological Survey, Room A-413 Federal Building-U.S. Courthouse, Nashville, Tennessee 37203. 


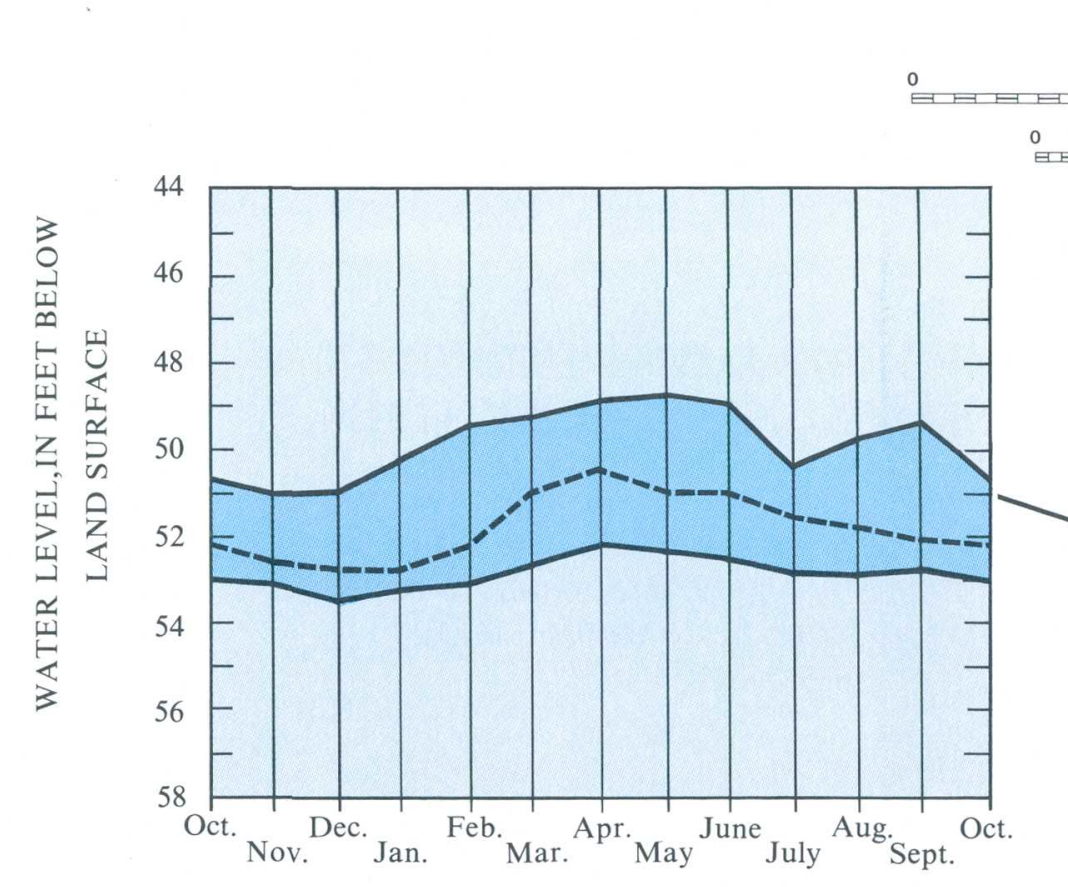

LOCAL WELL NO: :Pm:C-1 WELL DEPTH: 175 feet CASING DEPTH:60 feet TOPOGRAPHIC SETTING: On hilltop drainage divide, 1500 feet southwest of nearest point of natural discharge; near other wells.
not AQUIFER: Mississippian carbonate rocks

PERIOD OF RECORD: March 1968 to September 1979

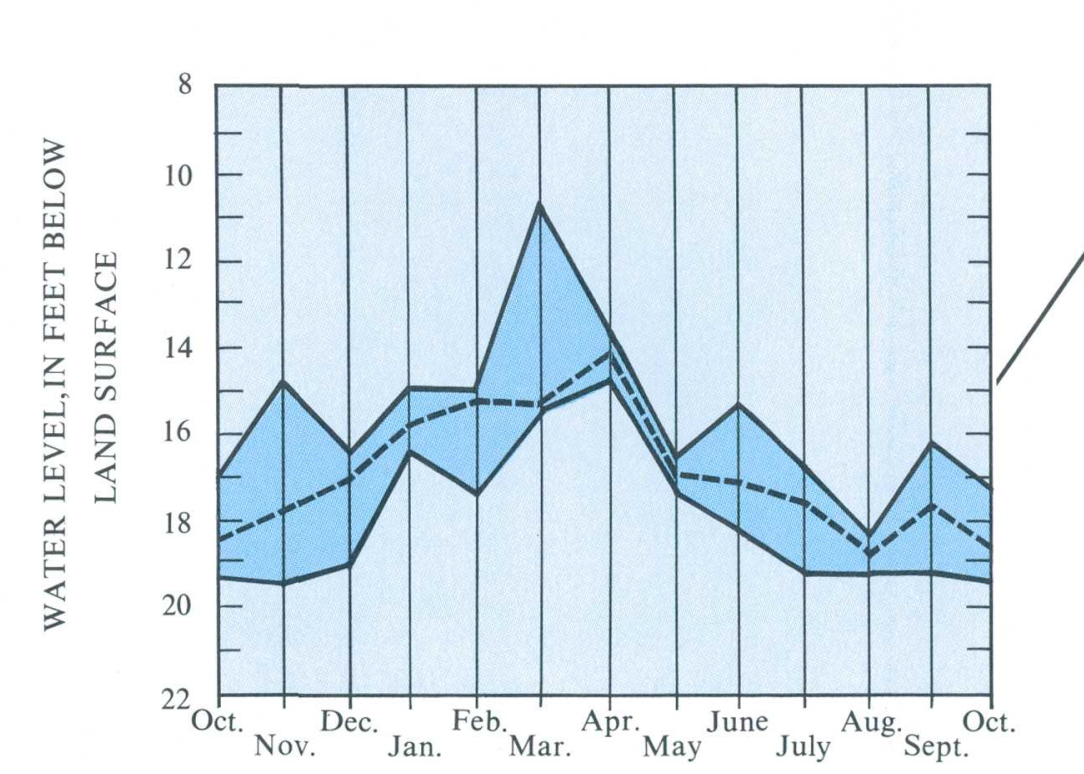

ALE 1:750,000 $=10 \quad 20 \quad 30$ KILOMETERS

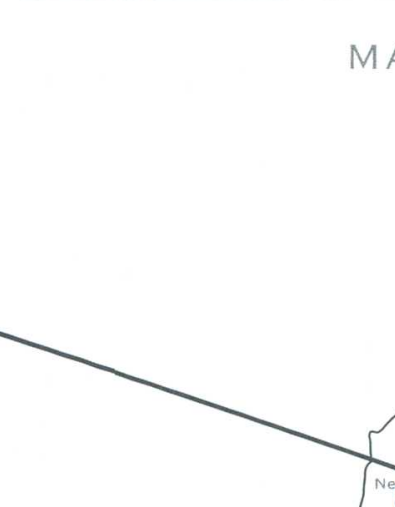

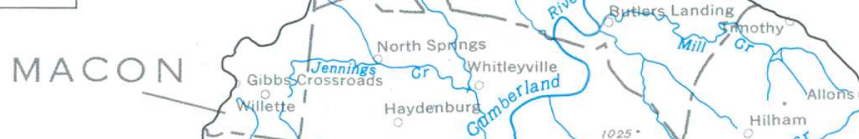

Median low of record

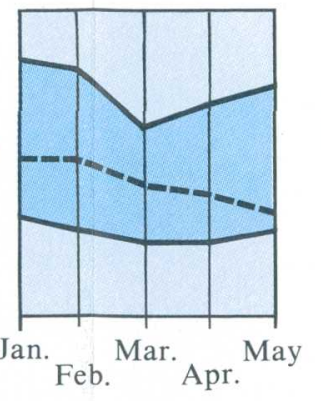

Dark tone designates extremes for Dest water level on 25 th or near

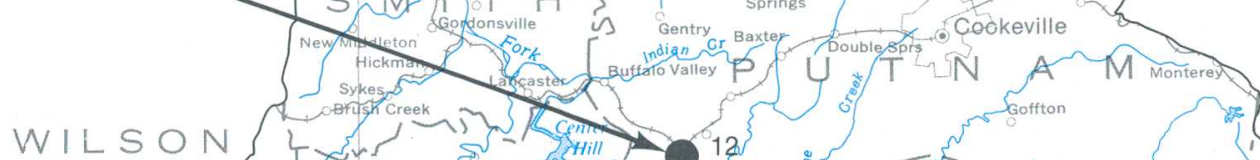
Y tratesvite OANNDN

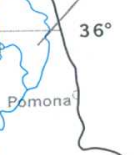

WELL NO.:Cn:D-1 WELL DEPTH:30 feet CASING DEPTH:Unknown

TOPOGRAPHIC SETTING: On drainage divide at the foot of a long slope,

200 feet west of nearest point of natural discharge.

AQUIFER: Ordovician limestone

PERIOD OF RECORD: April 1967 to September 1979

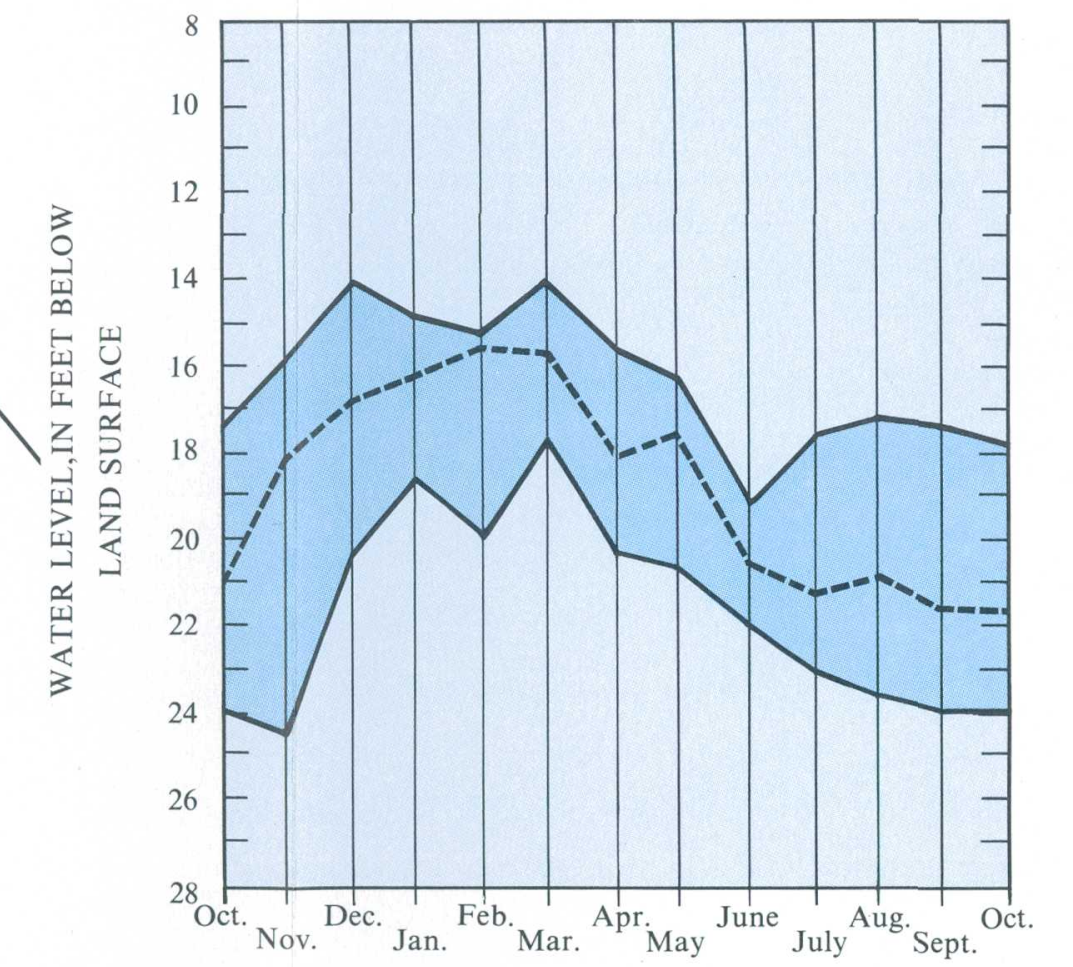

LOCAL WELL NO.: Cu:C-1 WELL DEPTH:69 feet CASING DEPTH:69 feet TOPOGRAPHIC SETTING: On flat drainage divide, 1000 feet west of neares point of natural discharge.

AQUIFER: Pennsylvanian sandstone

PERIOD OF RECORD: Sept. 1964 to Sept. 1975 


\title{
7.0 QUALITY OF SURFACE WATER \\ 7.1 Introduction
}

\section{WATER-QUALITY INFORMATION NEEDED TO EVALUATE EFFECTS OF MINING ACTIVITIES}

\author{
A network of 16 stations was established in 1979 to measure baseline \\ water-quality conditions and to evaluate water-quality \\ trends in coal resources areas.
}

The effects of surface coal-mining activities on the hydrologic environment often can be evaluated by using water-quality data. In 1979, a network of 16 stations was established in Area 18 (fig. 7.1-1). The water-quality data collected at those stations are presented in this report. Several important points, however, must be considered regarding those waterquality data.

(1) The term "quality" is not precise. The quality of water from any source cannot be defined unless the intended use is considered. The use itself, in fact, probably has the greatest effect on suitability.
(2) The water-quality data collected in Area 18 emphasized those parameters specified in the Act.

(3) Locally severe water-quality problems may exist at unsampled or unmeasured sites near any of the 16 sampling locations and not be detectable at the sampling locations. None of the 16 sampling stations were located, and none are planned, to directly sample mine drainage or seepage, or other point effluents. 


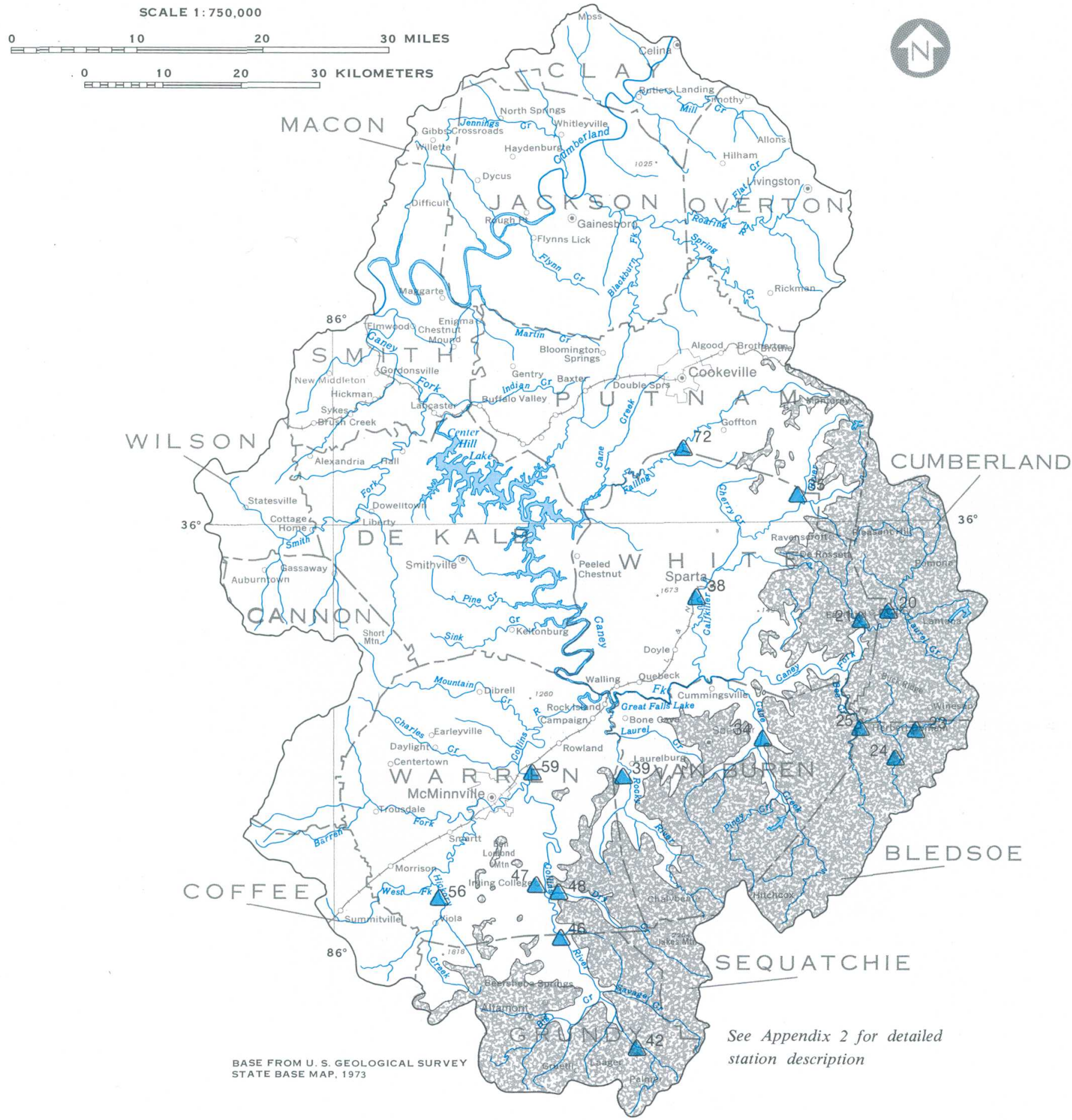

EXPLANATION

\section{Coal resources area}

$\triangle^{20}$ Active station and number

Figure 7.1-1 Location of stations 


\title{
7.0 QUALITY OF SURFACE WATER (Continued) \\ 7.2 Specific Conductance and Dissolved Solids
}

\section{SPECIFIC CONDUCTANCE AND DISSOLVED SOLIDS GENERALLY LOW}

\author{
Specific conductance ranged 26 to $675 \mu \mathrm{mho} / \mathrm{cm}$; a small variation \\ at most stations caused by flow differences was observed \\ during the year. Dissolved-solids concentrations \\ (estimated from specific conductance) were generally low.
}

The specific conductance of water in streams in the area rarely exceeded $250 \mu \mathrm{mho} / \mathrm{cm}$ at stations sampled during high, median and low flow periods in 1979. Also, at most stations only small variations were observed during the year (fig. 7.2-1). The combination of these two factors indicates that the quality of water with respect to major chemical constituents is suitable for most uses with minimum treatment.

The specific conductance of water in most streams was lowest for the high-flow sample in May. Areawide, conductance ranged from $26 \mu \mathrm{mho} / \mathrm{cm}$ in water in Bee Creek at Winesap (site 23) to 675 $\mu \mathrm{mho} / \mathrm{cm}$ in water in Clifty Creek at Mobra (site 21). Clifty Creek drains an area containing extensive mining activities.
Although specific conductance is not included in any commonly-used water-quality criteria, several parameters for which limits are specified (such as concentrations of dissolved solids or of major chemical constituents) often can be estimated from specific conductance data (Hem, 1970). An estimate of the dissolved-solids concentration in water in most streams in the area can be obtained by multiplying the conductance value by 0.65 . This factor can be used because most water in streams in the area is a calcium or sodium bicarbonate type. Therefore, based on currently available data, dissolved solids are generally less than 200 milligrams per liter $(\mathrm{mg} / \mathrm{L})$, low by most criteria. 


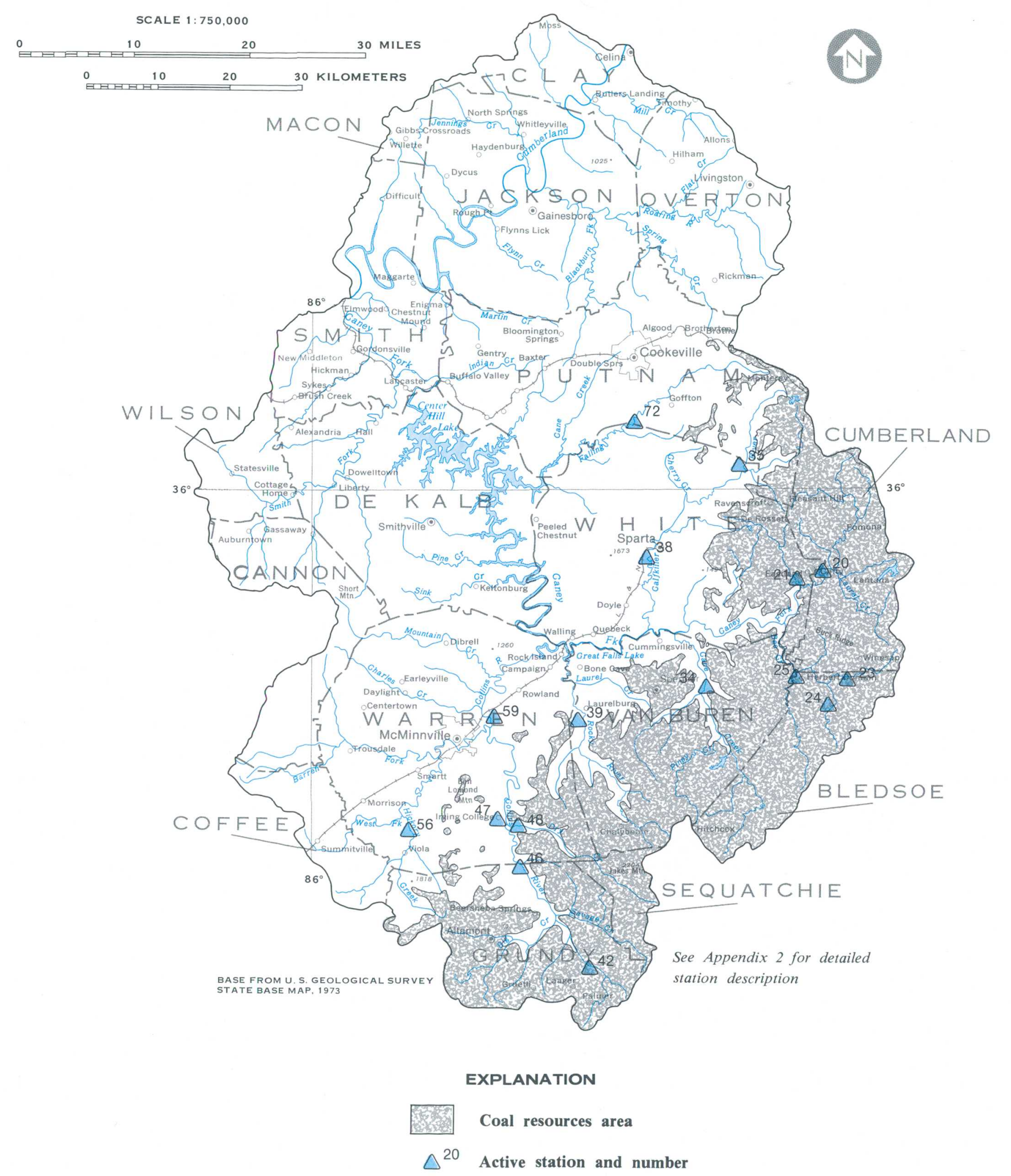

Figure 7.2-1 Specific conductance values at selected station
$\Delta^{20}$
99
35

460
675

400

60
26

57
68

36

48
75
44

72
100

100
70

150
235

190

220
252

217

200
265
110

68

95
42

58
91

250
290

102
208

130

245
232

242

190
158

180
240

$\begin{array}{cl}851 & \text { High } \\ 9.0 & \text { Low } \\ 146 & \text { Median } \\ 4.6 & \text { High } \\ .13 & \text { Low } \\ 1.6 & \text { Median } \\ 228 & \text { High } \\ .50 & \text { Low } \\ 24 & \text { Median } \\ 88 & \text { High } \\ 2.2 & \text { Low } \\ 25 & \text { Median } \\ 142 & \text { High } \\ 7.2 & \text { Low } \\ 55 & \text { Median } \\ 8.2 & -- \\ 3.6 & \text { Low } \\ 8.8 & -- \\ 502 & \text { High } \\ 21 & \text { Low } \\ 82 & \text { Median } \\ 302 & \text { High } \\ 74 & \text { Low } \\ 235 & \text { Median } \\ 126 & \text { High } \\ 27 & \text { Low } \\ 64 & \text { Median } \\ 284 & \text { High } \\ 12 & \text { Low } \\ 42 & \text { Median } \\ 2870 & \text { High } \\ 244 & \text { Low } \\ 390 & \text { Median } \\ 27 & -- \\ 13 & \text { Low } \\ 36 & -- \\ 581 & \text { High } \\ 35 & \text { Low } \\ 89 & \text { Median } \\ 44 & -- \\ 44 & -- \\ 70 & -- \\ 818 & -- \\ 534 & -- \\ 1180 & -- \\ 43 & -- \\ 18 & - \\ 62 & \end{array}$




\title{
7.0 QUALITY OF SURFACE WATER (Continued) \\ 7.3 Dissolved Sulfate
}

\section{DISSOLVED SULFATE CONCENTRATIONS GENERALLY LOW}

\author{
Dissolved sulfate ranged from 3.2 to $270 \mathrm{mg} / \mathrm{L}$ \\ areawide and a small variation at most stations \\ caused by flow differences was observed.
}

Dissolved sulfate, one of the constituents commonly used to identify mine drainage, was generally low in water from most streams in the area. Sulfate concentrations were generally less than $30 \mathrm{mg} / \mathrm{L}$ in those streams sampled during 1979 . Only five concentrations exceeded $50 \mathrm{mg} / \mathrm{L}$ of which three were observed in Clifty Creek at Mobra (fig. 7.3-1).

Sulfate concentrations above baseline levels frequently occur in streams adversely affected by acidmine drainage because of the weathering of sulfur minerals in coal-mine spoil piles. Obviously, the magnitude of the effect is, in part, dependent on the chemical composition of the spoil piles, but variable sulfate concentrations of as much as $2,000 \mathrm{mg} / \mathrm{L}$ are not unusual in many areas affected by mining activities. The maximum concentration determined in Area 18, however, was $270 \mathrm{mg} / \mathrm{L}$.
In general, dissolved sulfate concentrations were highest during low flow, a result of less streamflow available for dilution. Differences caused by flow variations were small at most of the 16 stations. Sulfate concentrations from several streams in areas affected by mining activities were higher than those in streams in undisturbed areas.

An estimate of dissolved sulfate frequently can be obtained using specific conductance data. Although no statistically significant relation between sulfate and conductance has yet been established for surface water in the area, some differences between water in streams draining mined areas and those draining undisturbed areas are apparent (fig. 7.3-2).

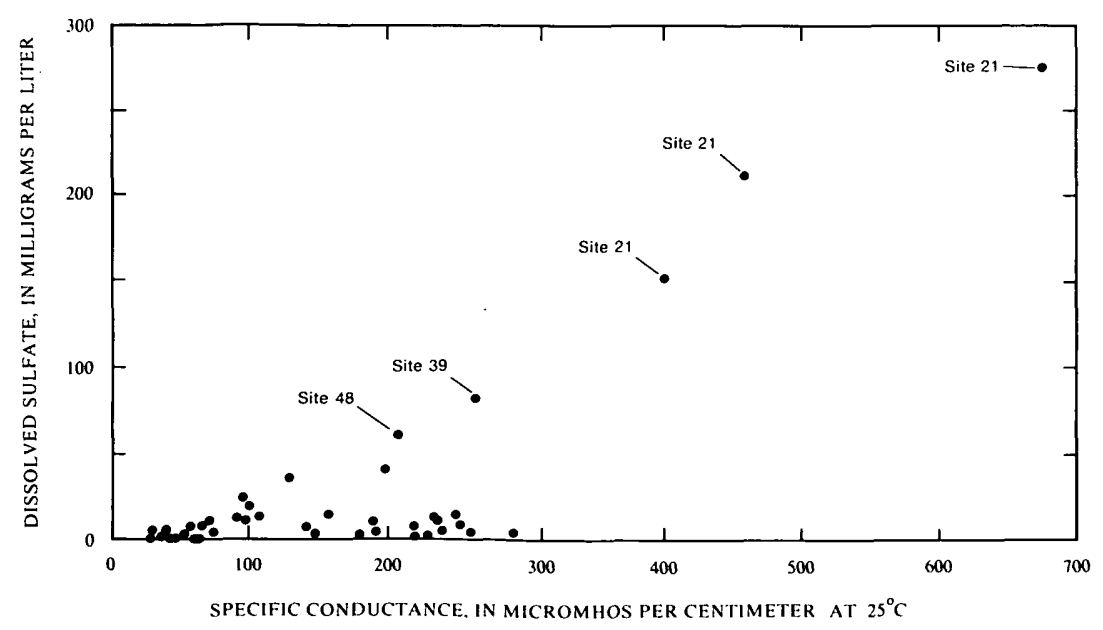

Figure 7.3-2 Relation between dissolved sulfate and specific conductance in water in streams 


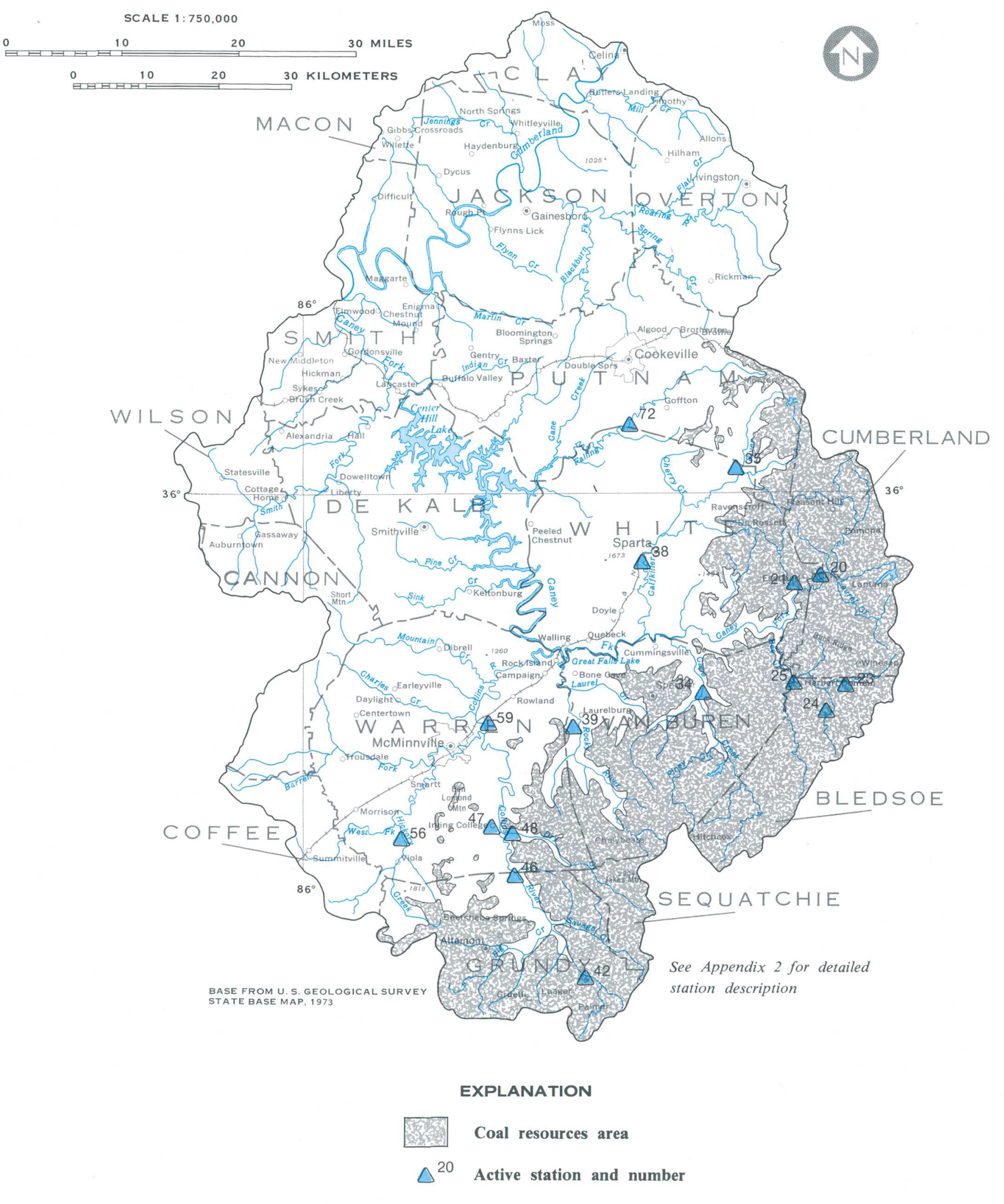

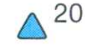

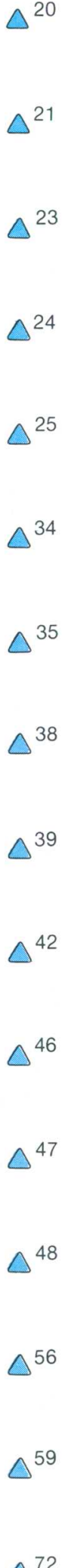

$\triangle^{34}$

Figure 7.3-1 Dissolved sulfate concentrations, in milligrams per liter, at selected stations $\triangle^{24}$

$\triangle^{25}$

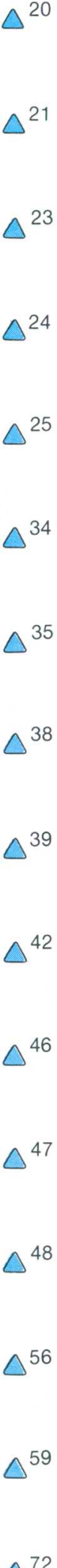

$\triangle^{38}$

$\triangle^{39}$

$\triangle^{42}$

$\triangle^{46}$

$\triangle^{47}$

$\Delta^{48}$

$\triangle^{56}$

$\triangle^{72}$

\section{7}

28

6.8

220
270

150

6.1
3.8

3.8
4.2

7.2

4.3

5.2

2

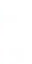

14
12
DISCHARGE
cubic teet per second

$\begin{array}{cl}851 & \text { High } \\ 9.0 & \text { Low } \\ 146 & \text { Median } \\ 4.6 & \text { High } \\ .13 & \text { Low } \\ 1.6 & \text { Median } \\ 228 & \text { High } \\ .50 & \text { Low } \\ 24 & \text { Median } \\ 88 & \text { High } \\ 2.2 & \text { Low } \\ 25 & \text { Median } \\ 142 & \text { High } \\ 7.2 & \text { Low } \\ 55 & \text { Median } \\ 8.2 & -- \\ 3.6 & \text { Low } \\ 8.8 & -- \\ 502 & \text { High } \\ 21 & \text { Low } \\ 82 & \text { Median } \\ 302 & \text { High } \\ 74 & \text { Low } \\ 235 & \text { Median } \\ 126 & \text { High } \\ 27 & \text { Low } \\ 64 & \text { Median } \\ 284 & \text { High } \\ 12 & \text { Low } \\ 42 & \text { Median } \\ 2870 & \text { High } \\ 244 & \text { Low } \\ 390 & \text { Median } \\ 27 & -- \\ 13 & \text { Low } \\ 36 & -- \\ 581 & \text { High } \\ 35 & \text { Low } \\ 89 & \text { Median } \\ 44 & -- \\ 44 & -- \\ 70 & -- \\ 818 & -- \\ 534 & -- \\ 1180 & -- \\ 43 & -- \\ 18 & - \\ 62 & \end{array}$




\subsection{QUALITY OF SURFACE WATER (Continued) $7.4 \mathrm{pH}$}

\section{PH RANGED BETWEEN 6.3 AND 8.2 UNITS}

\section{Acid-mine drainage is not a widespread problem in Area 18. \\ However, locally it may be a problem if mining is intensive and dilution by streamflow is low.}

The $\mathrm{pH}$ scale is a system which is used to express the relative acidity or alkalinity of any solution. A $\mathrm{pH}$ of 7.0 units indicates a neutral solution. Progressively lower $\mathrm{pH}$ values indicate an increasingly acidic solution, and progressively higher $\mathrm{pH}$ values indicate an increasingly alkaline solution.

The $\mathrm{pH}$ of water affects its suitability for many uses. Evaluation of the possible effect of acid-mine drainage is important because acidic water adversely affects most substances with which it comes in contact. Acidity, however, has important sources other than mine drainage. Some natural sources of acidity in water include rainfall, reaction of rainfall with organic matter in soils, and weathering of geologic strata.

The $\mathrm{pH}$ of water in most streams for which measurements were obtained in 1979, ranged from 6.3 to 8.2 units. Most lower $\mathrm{pH}$ values occurred during high flow. However, the range of measured values at each site is small, generally less than $1.0 \mathrm{pH}$ unit. No widespread acid-mine drainage problem is evident (fig. 7.4-1).

Lower $\mathrm{pH}$ values generally occurred in streams draining areas affected by mining activities. Water from Clifty Creek at Mobra was the most seriously affected where $\mathrm{pH}$ measurements of $3.5,3.5$ and 3.7 units were obtained.

Water in streams in the area is weakly buffered. Consequently, significant changes in the $\mathrm{pH}$ of water can be caused by the addition of small amounts of acidic or alkaline effluents. Changes in $\mathrm{pH}$, more acidic or more alkaline, can occur at low flow, caused by the lack of streamflow for dilution; or at high flow, caused by mine drainage or by the leaching of spoil piles. 


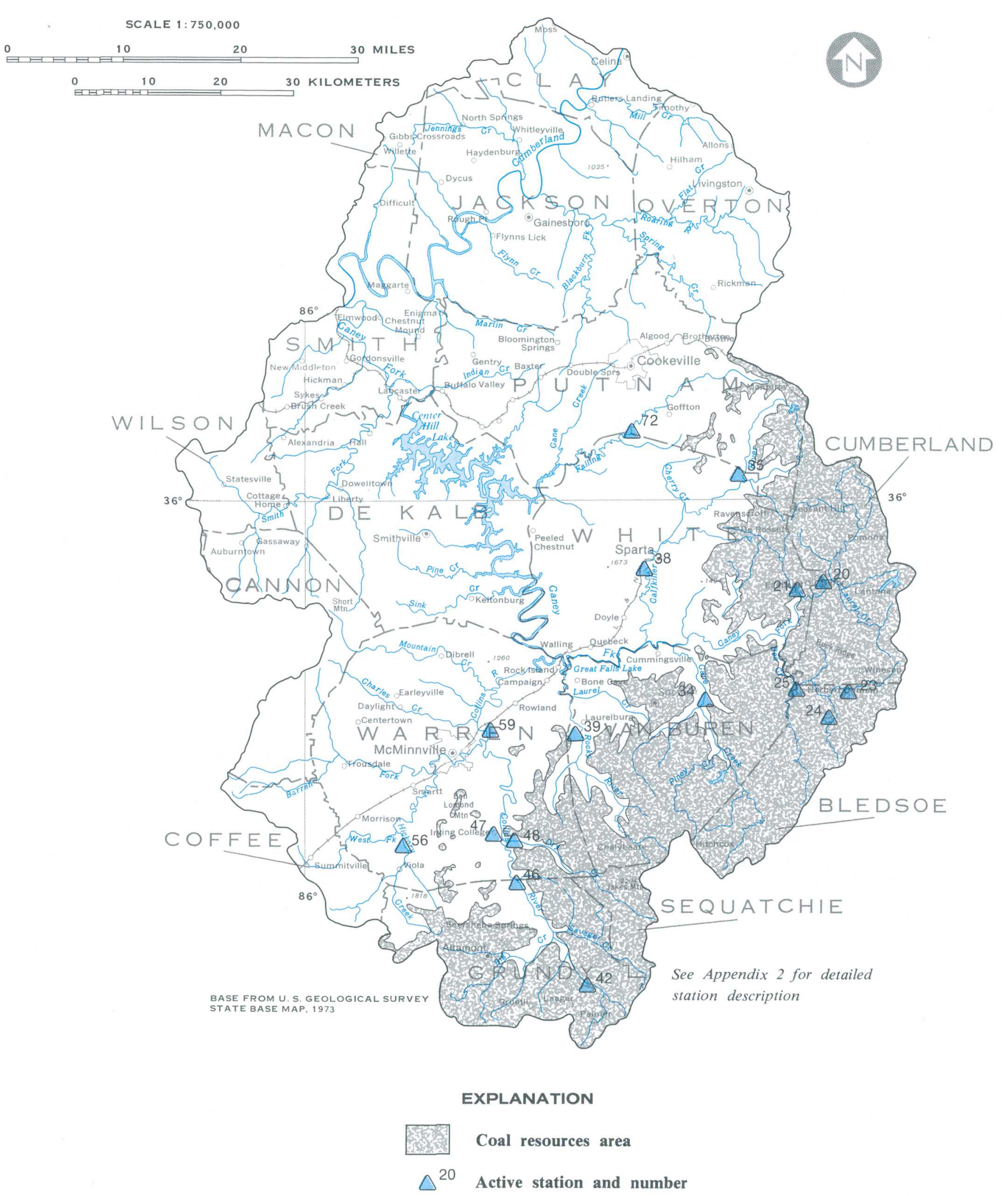

Figure 7.4-1 Measured pH values at selected stations

\begin{tabular}{|c|c|}
\hline$\Delta^{20}$ & $\begin{array}{l}7.0 \\
6.4\end{array}$ \\
\hline$\Delta^{21}$ & $\begin{array}{l}3.5 \\
3.5 \\
3.7\end{array}$ \\
\hline$\Delta^{23}$ & $\begin{array}{l}7.1 \\
6.7 \\
6.6\end{array}$ \\
\hline$\Delta^{24}$ & $\begin{array}{l}6.5 \\
7.3 \\
7.0\end{array}$ \\
\hline$\Delta^{25}$ & $\begin{array}{l}6.5 \\
8.0 \\
6.3\end{array}$ \\
\hline$\Delta^{34}$ & $\begin{array}{l}7.2 \\
7.8 \\
7.8\end{array}$ \\
\hline$\Delta^{35}$ & $\begin{array}{l}7.8 \\
7.9 \\
7.6\end{array}$ \\
\hline$\Delta^{38}$ & $\begin{array}{l}8.1 \\
8.2 \\
7.9\end{array}$ \\
\hline$\Delta^{39}$ & $\begin{array}{l}7.8 \\
7.8 \\
8.5\end{array}$ \\
\hline$\Delta^{42}$ & $\begin{array}{l}7.0 \\
7.1 \\
7.0\end{array}$ \\
\hline$\Delta^{46}$ & $\begin{array}{l}7.1 \\
7.7 \\
7.5\end{array}$ \\
\hline$\Delta^{47}$ & $\begin{array}{l}8.1 \\
7.9 \\
8.2\end{array}$ \\
\hline$\Delta^{48}$ & $\begin{array}{l}7.1 \\
7.4 \\
7.7\end{array}$ \\
\hline$\Delta^{56}$ & $\begin{array}{l}8.1 \\
7.9 \\
7.8\end{array}$ \\
\hline$\Delta^{59}$ & $\begin{array}{l}8.1 \\
7.9 \\
7.6\end{array}$ \\
\hline$\Delta^{72}$ & $\begin{array}{l}7.7 \\
7.8 \\
7.8\end{array}$ \\
\hline
\end{tabular}

$\begin{array}{cl}851 & \text { High } \\ 9.0 & \text { Low } \\ 146 & \text { Median } \\ 4.6 & \text { High } \\ 13 & \text { Low } \\ 1.6 & \text { Median } \\ 228 & \text { High } \\ .50 & \text { Low } \\ 24 & \text { Median } \\ 88 & \text { High } \\ 2.2 & \text { Low } \\ 25 & \text { Median } \\ 142 & \text { High } \\ 7.2 & \text { Low } \\ 55 & \text { Median } \\ 8.2 & -- \\ 3.6 & \text { Low } \\ 8.8 & -- \\ 502 & \text { High } \\ 21 & \text { Low } \\ 82 & \text { Median } \\ 302 & \text { High } \\ 74 & \text { Low } \\ 235 & \text { Median } \\ 126 & \text { High } \\ 27 & \text { Low } \\ 64 & \text { Median } \\ 284 & \text { High } \\ 12 & \text { Low } \\ 42 & \text { Median } \\ 2870 & \text { High } \\ 244 & \text { Low } \\ 390 & \text { Median } \\ 27 & -- \\ 13 & \text { Low } \\ 36 & -- \\ 581 & \text { High } \\ 35 & \text { Low } \\ 89 & \text { Median } \\ 44 & -- \\ 44 & -- \\ 70 & -- \\ 818 & -- \\ 534 & -- \\ 1180 & -- \\ 43 & -- \\ 18 & -- \\ 62 & \end{array}$




\subsection{QUALITY OF SURFACE WATER (Continued) \\ 7.5 Iron}

\section{IRON CONCENTRATIONS VARY WITH STREAMFLOW AND LOCATION}

\section{Although iron concentrations vary with streamflow and between sites, the concentrations of total recoverable iron in most streams were generally less than the mandatory limits specified for effluents from mining areas.}

Because excessive concentrations of iron can limit severely the use of water for public supply, domestic and recreational purposes, most watersupply criteria contain recommended maximum limits for dissolved iron. The Act specifies 7,000 micrograms per liter $(\mu \mathrm{g} / \mathrm{L})$ as the maximum allowable concentrations of total recoverable iron in effluents from mining operations. (Total recoverable iron includes both the dissolved and the suspended concentrations.) To satisfy these data needs, the total recoverable and the dissolved concentrations of iron were determined in water from selected sites in Area 18 during 1979 (fig. 7.5-1).

The maximum total recoverable iron in water from most stations occurred during high flows because large amounts of suspended iron were transported with suspended sediment. Total recoverable iron in water from the Calfkiller River near Taylors (site 35) and the Collins River at Barkertown (site 42) exceeded the maximum allowable concentration for mine effluents. These concentrations, $15,000 \mu \mathrm{g} / \mathrm{L}$ in the Calfkiller River and 7,300 $\mu \mathrm{g} / \mathrm{L}$ in the Collins River are equivalent to the transport of 20 tons/day (tons per day) and 5.6 tons/day of iron, respectively (assuming the instantaneous concentrations and streamflow were sustained throughout the day). Total recoverable iron concentrations ranged from 100 to $3,000 \mu \mathrm{g} / \mathrm{L}$ in the remaining streams. Concentrations were generally less than $500 \mu \mathrm{g} / \mathrm{L}$ in the relatively undisturbed areas.

Although pH is an important control on metal solubilities, no significant relation between $\mathrm{pH}$ and dissolved iron was found. However, water in several streams draining areas affected by mining activities contained dissolved iron in excess of what might be considered "background" levels (fig. 7.5-2).

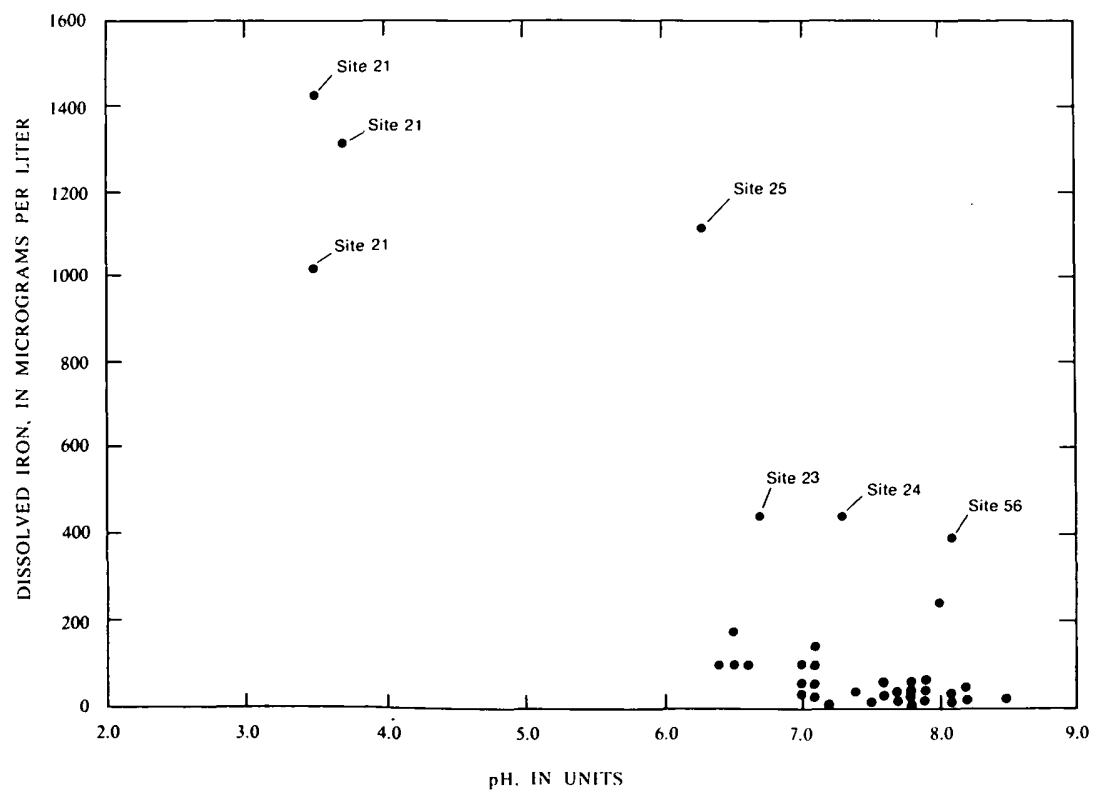

Figure 7.5-2 Relation between dissolved iron and $\mathrm{pH}$ in water in streams 
STATION NUMBER

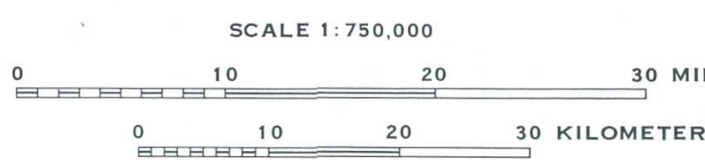

(20)

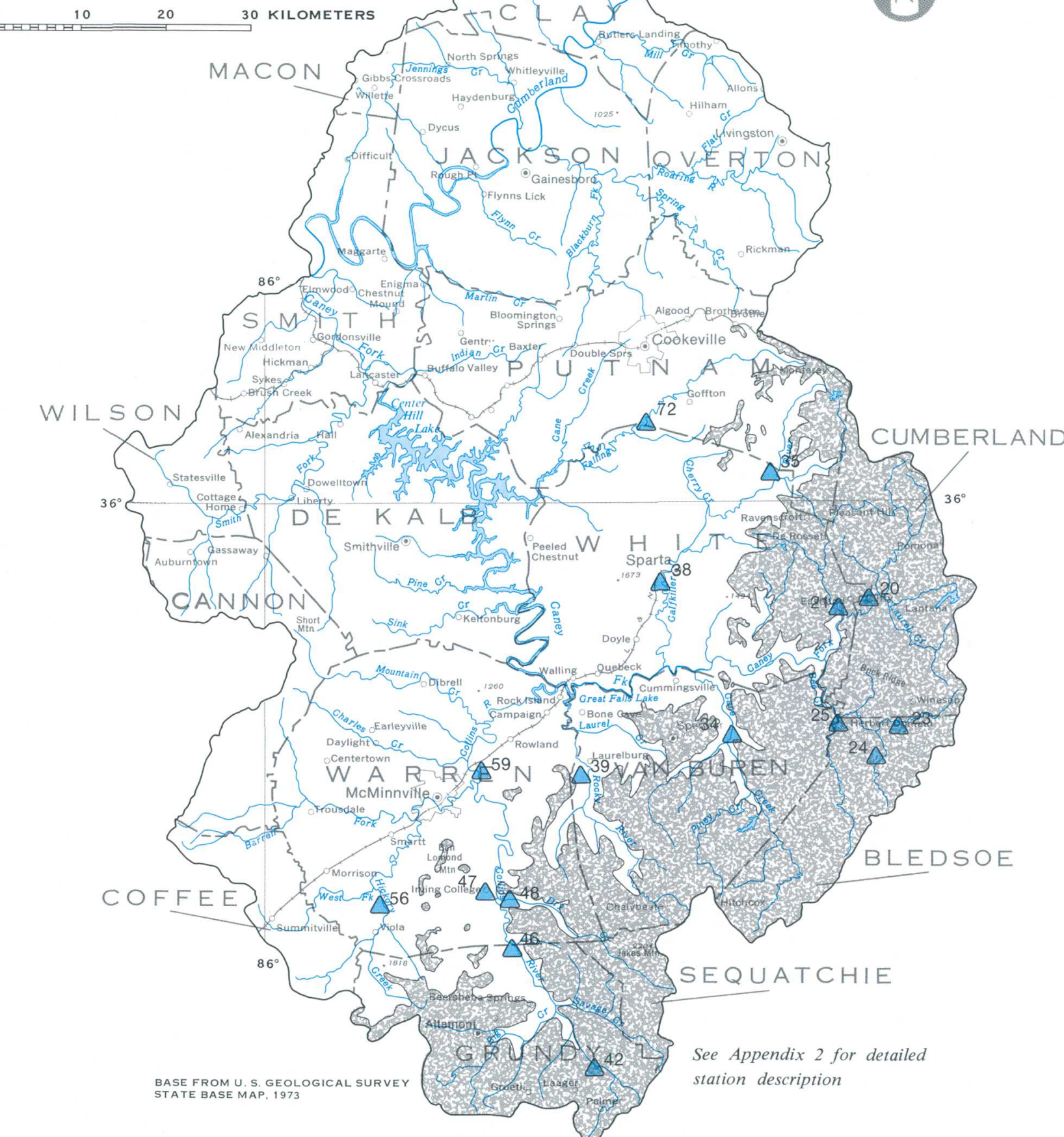

EXPLANATION

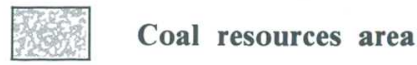

$\triangle^{20}$ Active station and number

Figure 7.5-1 Total recoverable iron concentrations, in micrograms per liter
TOTAL RECOVERABLE

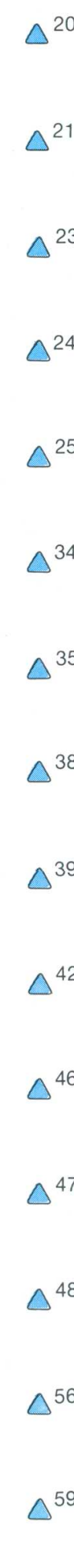

$\triangle^{72}$
DISCHARGE
(cubic feet per second)

\begin{tabular}{|c|c|c|}
\hline $\begin{array}{r}390 \\
200 \\
90\end{array}$ & $\begin{array}{c}851 \\
9.0 \\
146\end{array}$ & $\begin{array}{l}\text { High } \\
\text { Low } \\
\text { Median }\end{array}$ \\
\hline $\begin{array}{l}1,400 \\
1,000 \\
1,300\end{array}$ & $\begin{array}{l}4.6 \\
.13 \\
1.6\end{array}$ & $\begin{array}{l}\text { High } \\
\text { Low } \\
\text { Median }\end{array}$ \\
\hline $\begin{array}{r}3,000 \\
1,100 \\
310\end{array}$ & $\begin{array}{l}228 \\
24\end{array}{ }^{.50}$ & $\begin{array}{l}\text { High } \\
\text { Low } \\
\text { Median }\end{array}$ \\
\hline $\begin{array}{r}1,900 \\
760 \\
330\end{array}$ & $\begin{array}{c}88 \\
2.2 \\
25\end{array}$ & $\begin{array}{l}\text { High } \\
\text { Low } \\
\text { Median }\end{array}$ \\
\hline $\begin{array}{r}1,700 \\
370 \\
--\end{array}$ & $\begin{array}{c}142 \\
7.2 \\
55\end{array}$ & $\begin{array}{l}\text { High } \\
\text { Low } \\
\text { Median }\end{array}$ \\
\hline $\begin{array}{l}100 \\
100 \\
110\end{array}$ & $\begin{array}{l}8.2 \\
3.6 \\
8.8\end{array}$ & $\begin{array}{l}-- \\
\text { Low } \\
--\end{array}$ \\
\hline $\begin{array}{r}15,000 \\
190 \\
250\end{array}$ & $\begin{array}{r}502 \\
21 \\
82\end{array}$ & $\begin{array}{l}\text { High } \\
\text { Low } \\
\text { Median }\end{array}$ \\
\hline $\begin{array}{l}430 \\
270 \\
270\end{array}$ & $\begin{array}{r}302 \\
74 \\
235\end{array}$ & $\begin{array}{l}\text { High } \\
\text { Low } \\
\text { Median }\end{array}$ \\
\hline $\begin{array}{r}r 60 \\
90 \\
130\end{array}$ & $\begin{array}{r}126 \\
27 \\
64\end{array}$ & $\begin{array}{l}\text { High } \\
\text { Low } \\
\text { Median }\end{array}$ \\
\hline $\begin{array}{r}7,300 \\
410 \\
200\end{array}$ & $\begin{array}{r}284 \\
12 \\
42\end{array}$ & $\begin{array}{l}\text { High } \\
\text { Low } \\
\text { Median }\end{array}$ \\
\hline $\begin{array}{l}780 \\
140 \\
130\end{array}$ & $\begin{array}{r}2870 \\
244 \\
390\end{array}$ & $\begin{array}{l}\text { High } \\
\text { Low } \\
\text { Median }\end{array}$ \\
\hline $\begin{array}{l}500 \\
130 \\
150\end{array}$ & $\begin{array}{l}27 \\
13 \\
36\end{array}$ & $\begin{array}{l}-\overline{-} \\
\text { Low }\end{array}$ \\
\hline $\begin{array}{r}1,600 \\
130 \\
220\end{array}$ & $\begin{array}{r}581 \\
35 \\
89\end{array}$ & $\begin{array}{l}\text { High } \\
\text { Low } \\
\text { Median }\end{array}$ \\
\hline $\begin{array}{l}-\overline{420} \\
240\end{array}$ & $\begin{array}{l}44 \\
44 \\
70\end{array}$ & $\begin{array}{l}-- \\
-- \\
--\end{array}$ \\
\hline $\begin{array}{l}400 \\
290 \\
170\end{array}$ & $\begin{array}{r}818 \\
534 \\
1180\end{array}$ & $\begin{array}{l}-- \\
-- \\
--\end{array}$ \\
\hline $\begin{array}{r}1200 \\
300 \\
270\end{array}$ & $\begin{array}{l}43 \\
18 \\
62\end{array}$ & \\
\hline
\end{tabular}




\title{
7.0 QUALITY OF SURFACE WATER (Continued) 7.6 Manganese
}

\section{MANGANESE CONCENTRATIONS VARY WITH STREAMFLOW AND LOCATION}

\author{
The concentrations of total recoverable manganese in water in most \\ streams were generally less than the mandatory limits \\ specified for effluents from mining areas, but \\ varied with streamflow and location.
}

Excessive concentrations of manganese can limit severely the use of water for public supply, domestic and recreational purposes. As a result, most watersupply criteria contain recommended maximum limits for dissolved manganese. The maximum allowable concentrations of total recoverable manganese in effluents from mined areas specified in the Act is $4,000 \mu \mathrm{g} / \mathrm{L}$. (Total recoverable manganese includes both the dissolved and the suspended concentrations.) Both the total recoverable and the dissolved concentrations of manganese were determined in water from selected sites in Area 18 during 1979 (fig. 7.6-1).

Generally, higher concentrations of total recoverable manganese were determined in water in most streams during high flows because large amounts of suspended manganese were transported with suspended sediment. However, at most stations the differences in concentrations were small for the three flows sampled. Total recoverable manganese concentrations in water in Clifty Creek at Mobra exceeded the limit for each determination. No concentrations in other streams exceeded the limit.

Metal solubilities generally are affected significantly by $\mathrm{pH}$. However, no significant relation between $\mathrm{pH}$ and dissolved manganese has yet been determined areawide (fig. 7.6-2). Higher dissolved manganese concentrations have been determined in water in streams draining areas affected by mining activities.

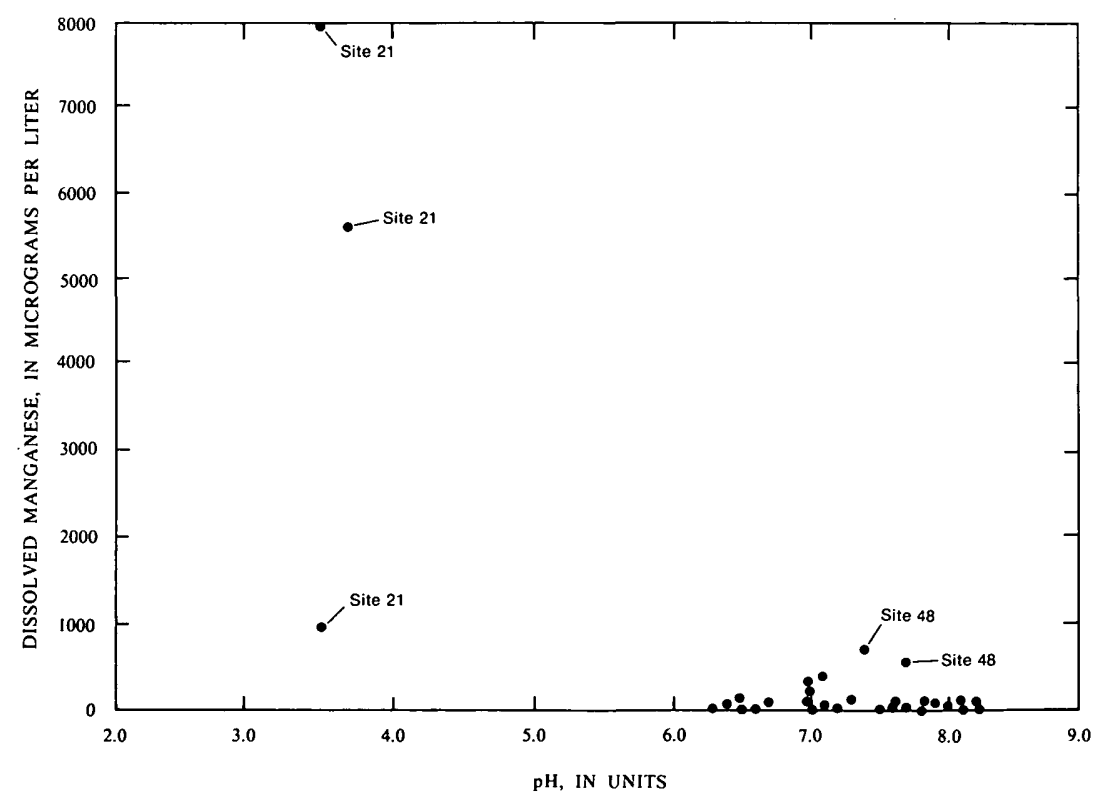

Figure 7.6-2 Relation between dissolved manganese and pH in water in streams 
STATION NUMBER

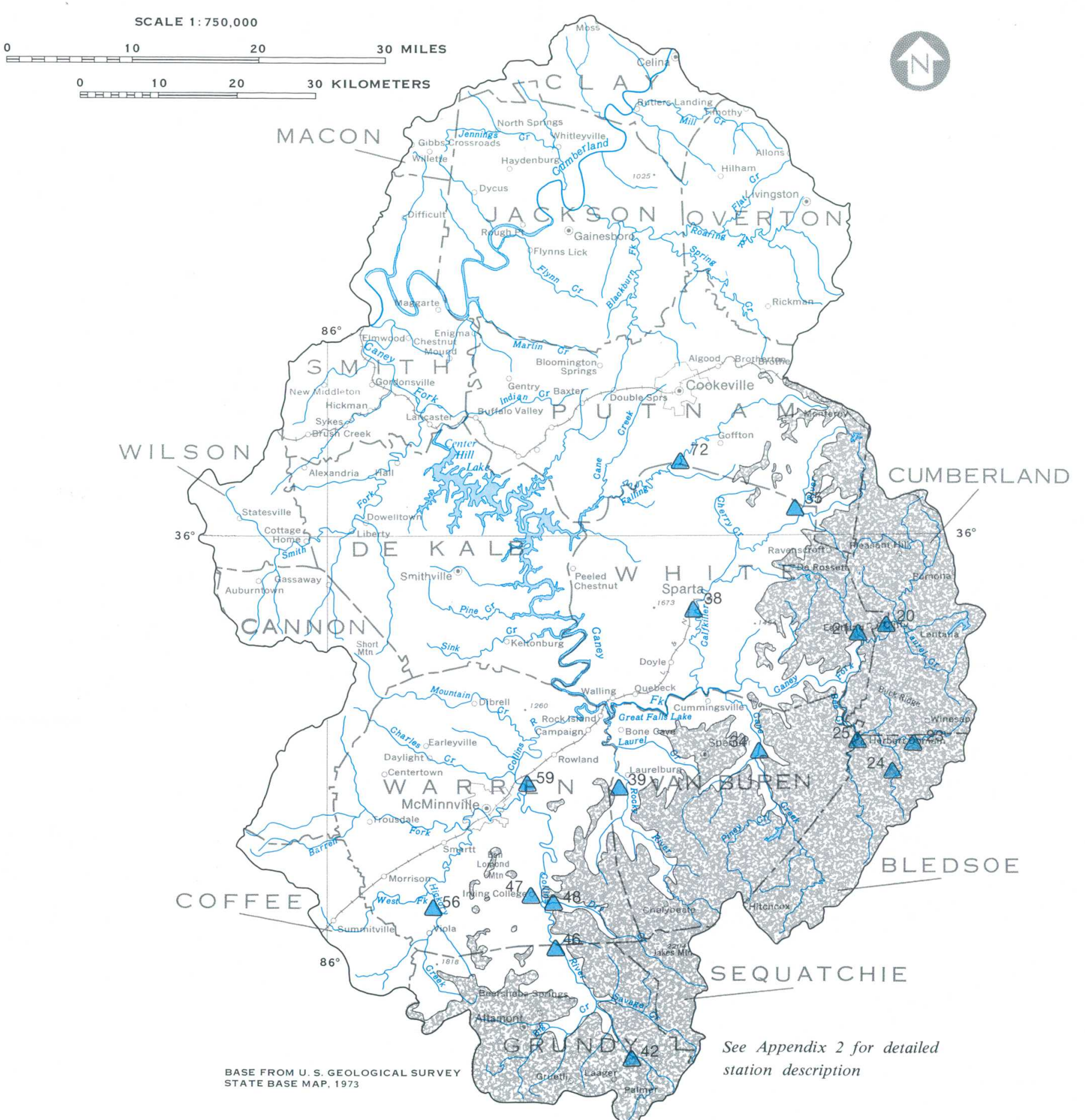

EXPLANATION

Coal resources area

$\triangle^{20}$ Active station and number

Figure 7.6-1 Total recoverable manganese concentrations, in micrograms per liter $\triangle^{20}$

$\triangle^{21}$

$\triangle^{23}$

$\triangle^{24}$

$\triangle^{25}$

$\triangle^{34}$

$\triangle^{35}$

$\triangle^{38}$

$\triangle^{39}$

$\triangle^{42}$

$\triangle^{46}$

$\triangle^{47}$

$\triangle^{48}$

$\triangle^{56}$

$\triangle^{59}$

$\triangle^{72}$
TOTAL RECOVERABLE
DISCHARGE
MANGANESE CONCENTRATION (cubic feet per second) (micrograms per liter)

\begin{tabular}{|c|c|c|}
\hline $\begin{array}{r}70 \\
270 \\
70\end{array}$ & $\begin{array}{c}851 \\
9.0 \\
146\end{array}$ & $\begin{array}{l}\text { High } \\
\text { Low } \\
\text { Median }\end{array}$ \\
\hline $\begin{array}{r}7,600 \\
11,000\end{array}$ & $\begin{array}{c}4.6 \\
.13\end{array}$ & $\begin{array}{l}\text { High } \\
\text { Low }\end{array}$ \\
\hline 5,600 & 1.6 & Median \\
\hline $\begin{array}{r}180 \\
70 \\
20\end{array}$ & ${ }_{24}^{228} .50$ & $\begin{array}{l}\text { High } \\
\text { Low } \\
\text { Median }\end{array}$ \\
\hline $\begin{array}{r}230 \\
120 \\
40\end{array}$ & $\begin{array}{c}88 \\
2.2 \\
25\end{array}$ & $\begin{array}{l}\text { High } \\
\text { Low } \\
\text { Median }\end{array}$ \\
\hline $\begin{array}{r}270 \\
40 \\
50\end{array}$ & $\begin{array}{c}142 \\
7.2 \\
55\end{array}$ & $\begin{array}{l}\text { High } \\
\text { Low } \\
\text { Median }\end{array}$ \\
\hline $\begin{array}{l}40 \\
20 \\
10\end{array}$ & $\begin{array}{l}8.2 \\
3.6 \\
8.8\end{array}$ & $\overline{\text { Low }}$ \\
\hline $\begin{array}{r}570 \\
20 \\
20\end{array}$ & $\begin{array}{r}502 \\
21 \\
82\end{array}$ & $\begin{array}{l}\text { High } \\
\text { Low } \\
\text { Median }\end{array}$ \\
\hline $\begin{array}{l}60 \\
40 \\
50\end{array}$ & $\begin{array}{r}302 \\
74 \\
235\end{array}$ & $\begin{array}{l}\text { High } \\
\text { Low }\end{array}$ \\
\hline $\begin{array}{r}200 \\
90 \\
10\end{array}$ & $\begin{array}{r}126 \\
27 \\
64\end{array}$ & $\begin{array}{l}\text { High } \\
\text { Low } \\
\text { Median }\end{array}$ \\
\hline $\begin{array}{r}810 \\
60 \\
30\end{array}$ & $\begin{array}{r}284 \\
12 \\
42\end{array}$ & $\begin{array}{l}\text { High } \\
\text { Low } \\
\text { Median }\end{array}$ \\
\hline $\begin{array}{r}160 \\
20 \\
10\end{array}$ & $\begin{array}{r}2870 \\
244 \\
390\end{array}$ & $\begin{array}{l}\text { High } \\
\text { Low }\end{array}$ \\
\hline $\begin{array}{l}40 \\
10 \\
10\end{array}$ & $\begin{array}{l}27 \\
13 \\
36\end{array}$ & Low \\
\hline 650 & $\begin{array}{r}581 \\
35\end{array}$ & $\begin{array}{l}\text { High } \\
\text { Low }\end{array}$ \\
\hline 600 & 89 & Median \\
\hline $\begin{array}{l}-- \\
60 \\
20\end{array}$ & $\begin{array}{l}44 \\
44 \\
70\end{array}$ & $\begin{array}{l}-- \\
--\end{array}$ \\
\hline $\begin{array}{l}50 \\
50 \\
40\end{array}$ & $\begin{array}{r}818 \\
534 \\
1180\end{array}$ & $\begin{array}{l}-- \\
--\end{array}$ \\
\hline $\begin{array}{l}90 \\
30 \\
20\end{array}$ & $\begin{array}{l}43 \\
18 \\
62\end{array}$ & -- \\
\hline
\end{tabular}




\title{
7.0 QUALITY OF SURFACE WATER (Continued) 7.7 Trace Constituents
}

\section{BOTTOM MATERIALS CONTAINED SMALL CONCENTRATIONS OF TRACE CONSTITUENTS}

\author{
Small concentrations of trace constituents were found in bottom \\ material in stream channels at 16 stations in Area 18. No \\ potentially serious problems were detected.
}

\begin{abstract}
Selected trace constituents in bottom material in streambeds at 16 stations were determined in September 1979 (fig. 7.7-1). No widespread occurrence of any of the constituents in potentially troublesome quantities is evident.
\end{abstract}

Total recoverable trace-constituent concentrations in water in the Collins River near McMinnville (site 59) were determined during the low-flow period in September (table 7.7-2). (Total recoverable concentrations include both the dissolved and the suspended concentrations). None of the concentrations determined exceeded the mandatory or recommended criteria for public supply. No other trace-constituent concentrations from streams in Area 18 were obtained during the year, but future programs will include the collection of trace-constituent data.

Several important facts should be considered in any interpretation of concentrations of constituents in bottom material.
- Limits for concentrations of trace constituents in streambeds have not been established.

- Mandatory or recommended criteria for concentrations of several dissolved or total recoverable trace constituents in water such as arsenic, lead, mercury, selenium, zinc and others are available.

- The presence of any constituent in bottom material at a particular site does not identify a source in the immediate area. The constituent probably was transported by a previous flow event.

- Large concentrations of constituents for which limits have been established are potentially troublesome because the constituents can be transported downstream by future high-flow events or can be put into solution or suspension by natural geochemical or biological processes. 


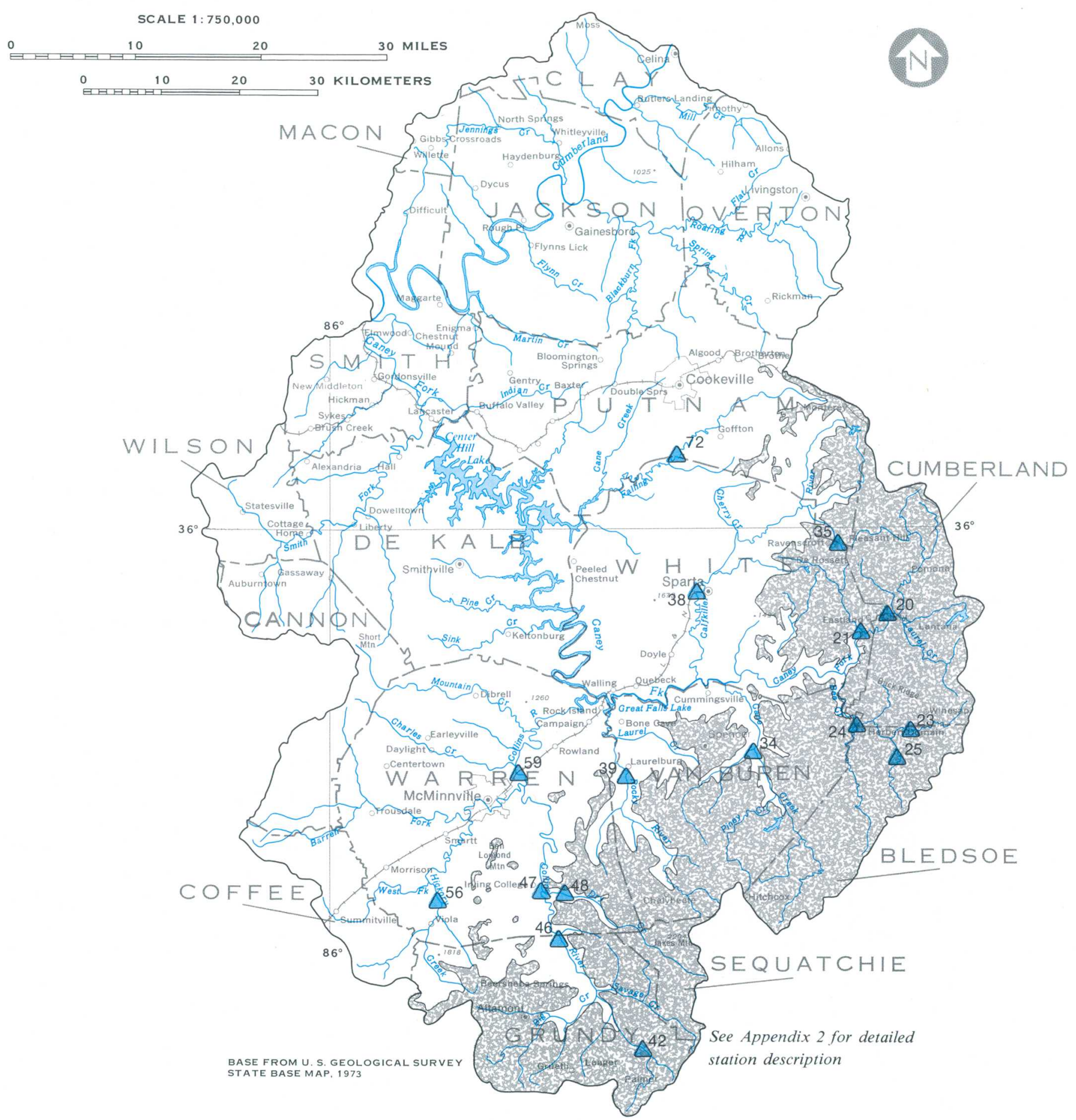

Coal resources area

$\triangle^{72}$ Active water-quality station and number Bottom-material station
Table 7.7-1 Recoverable trace constituent concentrations in bottom material from streams in Area 18 Concentrations, in micrograms per gram

$\begin{array}{lcc}\text { Constituent } & \text { Maximum } & \text { Minimum } \\ & & \\ \text { Arsenic } & 7 & 0 \\ \text { Cadmium } & 10 & 10 \\ \text { Chromium } & 40 & 10 \\ \text { Cobalt } & 20 & 10 \\ \text { Copper } & 10 & 10 \\ \text { Lead } & 130 & 10 \\ \text { Mercury } & 0 & 0 \\ \text { Selenium } & 0 & 0 \\ \text { Zinc } & 90 & 10 \\ \text { Note: Arsenic and selenium } & \text { concentrations } & \end{array}$

Note: Arsenic and selen are total concentration.

in water in Collins River near McMinnville (station 59), September, 1979

\section{Concentrations in micrograms per liter}

Arsenic (as As)

Barium (as $\mathrm{Ba}$ )

Cadmium (as Cd)

Chromium (as $\mathrm{Cr}$ )

Copper (as $\mathrm{Cu}$ )

Mercury (as $\mathrm{Hg}$ )

Lead (as $\mathrm{Pb}$ )

Selenium (as Se)

Silver (as $\mathrm{Ag}$ )

Zinc (as Zn)

$$
\begin{aligned}
& 0 \\
& 1 \\
& 10 \\
& 4 \\
& 0.5 \\
& 2
\end{aligned}
$$$$
3
$$$$
0
$$$$
\begin{array}{r}
0 \\
30
\end{array}
$$

Note: Arsenic and selenium concentration 


\title{
7.0 QUALITY OF SURFACE WATER (Continued) 7.8 Sediment
}

\section{SUSPENDED-SEDIMENT DATA LIMITED}

\author{
The limited suspended-sediment concentration data show large \\ variability thus only the most tenuous of correlations \\ can be made with land use.
}

The suspended-sediment yield for a particular drainage basin is controlled by many factors including topography, geology, soils, climate and land use. Changes in the suspended-sediment yield for a particular basin and differences in suspended-sediment yield among neighboring basins can usually be related to changes or differences in land use. The suspended-sediment yield for a particular basin is determined from the mean values of numerous instantaneous suspended-sediment discharge measurements covering a wide range of water discharges. In addition to the factors controlling suspended-sediment yield, each instantaneous suspended-sediment discharge measurement is also influenced by factors such as type of bed material, bed forms, position on hydrograph, location of sediment source area, distribution and intensity of precipitation, season, antecedent conditions, sampling and analytical errors. Thus, differences among small numbers of instantaneous suspended-sediment discharge measurements for a particular basin or neighboring basins cannot easily be related to differences in land use.

Beginning in 1979, suspended-sediment samples were collected at 16 stations. Suspended-sediment concentrations for low flow and median flow (table 7.8-1) ranged from $1 \mathrm{mg} / \mathrm{L}$ to $13 \mathrm{mg} / \mathrm{L}$, and instantaneous suspended-sediment discharges ranged from 0 to 16 tons/day. During the high-flow run (fig 7.8-1), suspended-sediment concentrations ranged from 14 to $831 \mathrm{mg} / \mathrm{L}$, and discharges ranged from
0.07 to 1,120 tons/day. The largest change in suspended-sediment concentration was for Calfkiller River (site 35) where concentration varied from 2 $\mathrm{mg} / \mathrm{L}$ during low flow $\left(83 \mathrm{ft}^{3} / \mathrm{s}\right)$ to $831 \mathrm{mg} / \mathrm{L}$ during high flow $\left(498 \mathrm{ft}^{3} / \mathrm{s}\right)$. This was also the highest concentration sampled during the high-flow run and the highest discharge $(1,120$ tons/day) calculated. The least change in concentration was found on Cane Creek (site 34) where the three samples had concentrations of $<1,3$ and $3 \mathrm{mg} / \mathrm{L}$. However, stream discharge for these samples did not include surface runoff.

Suspended sediment sampled during the highflow event consisted mostly of silt and clay size material. Of the 16 sediment samples taken during high flow, 9 contained more than 70 percent silt and clay, 5 contained between 50 and 70 percent silt and clay, while only 2 contained less than 50 percent silt and clay. Overall, the percentage of silt and clay in the 16 suspended-sediment samples ranged from 39 percent to 89 percent.

Site descriptions for the 16 sampling stations indicate that most channels have beds consisting of bedrock covered to varying degrees with boulders, cobbles and gravel. Some sand deposits were reported but no truly sand-bed channels or alluvial channels were observed. 


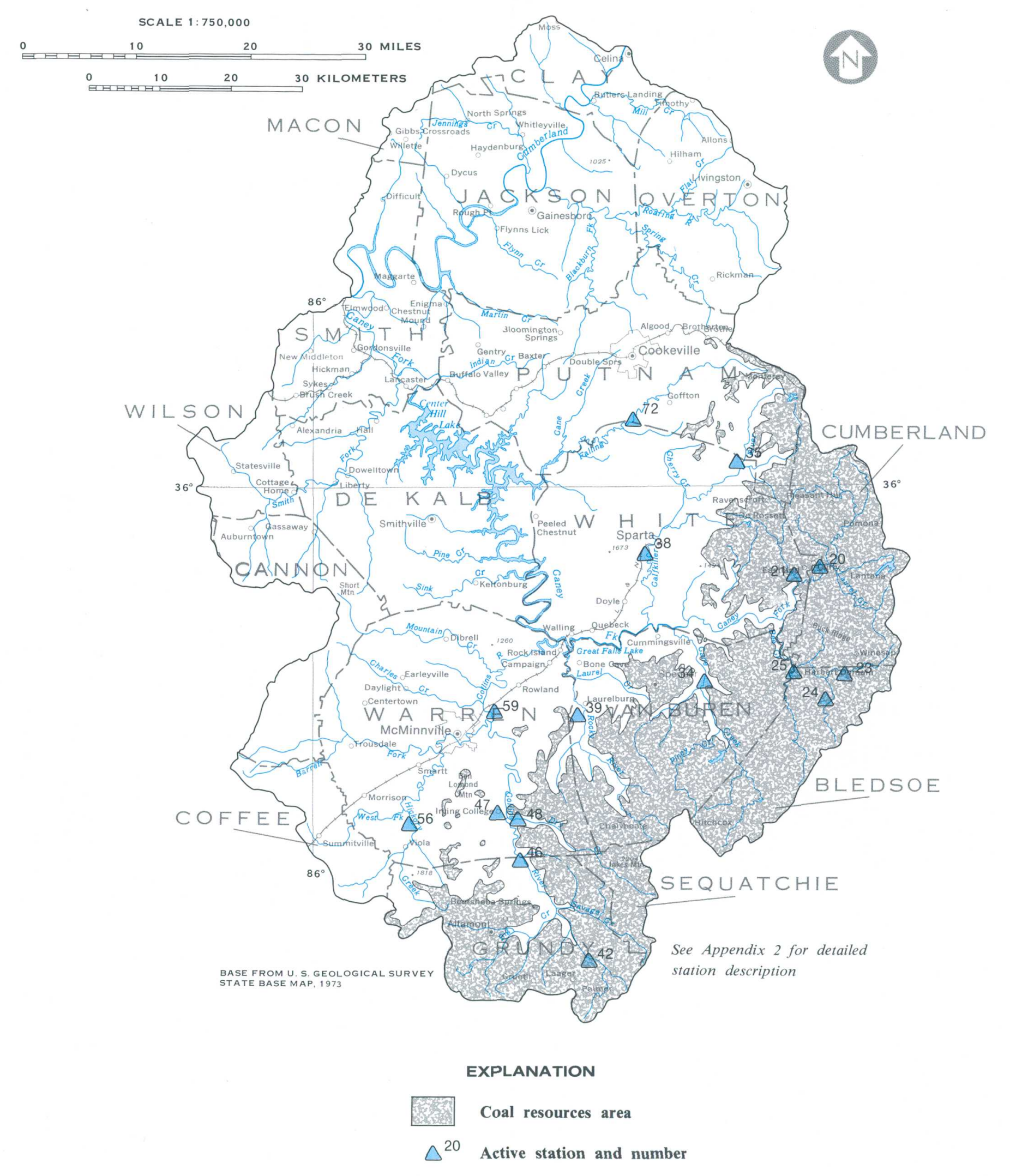

STATION NUMBER

\begin{tabular}{|c|c|}
\hline$\Delta^{20}$ & $\begin{array}{r}5-25-79 \\
9-5-79 \\
11-7-79\end{array}$ \\
\hline$\Delta^{21}$ & $\begin{array}{r}5-23-79 \\
9-5-79 \\
11-7-79\end{array}$ \\
\hline$\Delta^{23}$ & $\begin{array}{r}5-23-79 \\
9-5-79 \\
11-7-79\end{array}$ \\
\hline$\Delta^{24}$ & $\begin{array}{r}5-23-79 \\
9-5-79 \\
11-7-79\end{array}$ \\
\hline$\Delta^{25}$ & $\begin{array}{r}5-23-79 \\
9-5-79 \\
11-7-79\end{array}$ \\
\hline$\Delta^{34}$ & $\begin{array}{r}5-23-79 \\
9-5-79 \\
11-7-79\end{array}$ \\
\hline$\Delta^{35}$ & $\begin{array}{r}5-23-79 \\
9-5-79 \\
11-7-79\end{array}$ \\
\hline$\Delta^{38}$ & $\begin{array}{r}5-23-79 \\
9-5-79 \\
11-8-79\end{array}$ \\
\hline$\Delta^{39}$ & $\begin{array}{r}5-23-79 \\
9-5-79 \\
11-7-79\end{array}$ \\
\hline$\Delta^{42}$ & $\begin{array}{r}5-23-79 \\
9-4-79 \\
11-6-79\end{array}$ \\
\hline$\Delta^{46}$ & $\begin{array}{r}5-24-79 \\
9-5-79 \\
11-6-79\end{array}$ \\
\hline$\Delta^{47}$ & $\begin{array}{r}5-23-79 \\
9-5-79 \\
11-6-79\end{array}$ \\
\hline$\triangle^{48}$ & $\begin{array}{r}5-24-79 \\
9-5-79 \\
11-6-79\end{array}$ \\
\hline$\triangle^{56}$ & $\begin{array}{r}5-23-79 \\
9-5-79 \\
11-6-79\end{array}$ \\
\hline$\Delta^{59}$ & $\begin{array}{r}5-23-79 \\
9-5-79 \\
11-6-79\end{array}$ \\
\hline$\Delta^{72}$ & $\begin{array}{r}5-23-79 \\
9-6-79 \\
11-7-79\end{array}$ \\
\hline
\end{tabular}




\title{
8.0 QUALITY OF GROUND WATER
}

\section{CHEMICAL QUALITY OF GROUND WATER VARIES IN AREA 18}

\author{
Although ground-water quality has not been extensively measured \\ in the area, no widespread problems are apparent. Most \\ ground water developed is suitable for most uses with \\ minimum treatment. Hardness ranges from very soft \\ to very hard.
}

The water-quality program begun in the coalproducing region in 1979, has not yet been expanded to include needed quality of ground-water data. However, some data have been collected in other programs as recently as 1977 , although not all parameters specified in the Act are available at all wells (fig. 8.0-1). Evaluations of the chemical quality of ground water in Area 18 have been made as part of these other hydrologic studies. The evaluations suggest the following:

- Although ground-water quality in Area 18 varies widely from place to place (even between wells in any of the three major rock types), the water is generally suited for most uses.

- Water from most wells in the Cumberland Plateau is a soft to moderately hard, mixed type (calcium bicarbonate, sodium bicarbonate, or calcium sulfate type) containing relatively small amounts of dissolved solids. Locally, acidic water could be troublesome and some high concentrations of manganese are found. High chloride and high iron concentrations have been reported.

- Water from wells in the Highland Rim is generally a moderately hard to hard, calcium bicarbonate type containing moderate amounts of dissolved solids. High iron or manganese concentrations are not a widespread problem, but locally, high concentrations of both constituents have been reported. The $\mathrm{pH}$ of most water is greater than 7.0 units.

- Water from most wells in the Central Basin is a very hard, calcium bicarbonate type containing moderate amounts of dissolved solids. Iron and manganese concentrations generally are within watersupply criteria. No widespread water-quality problems are evident, although excessive fluoride concentrations have been reported in some areas. 


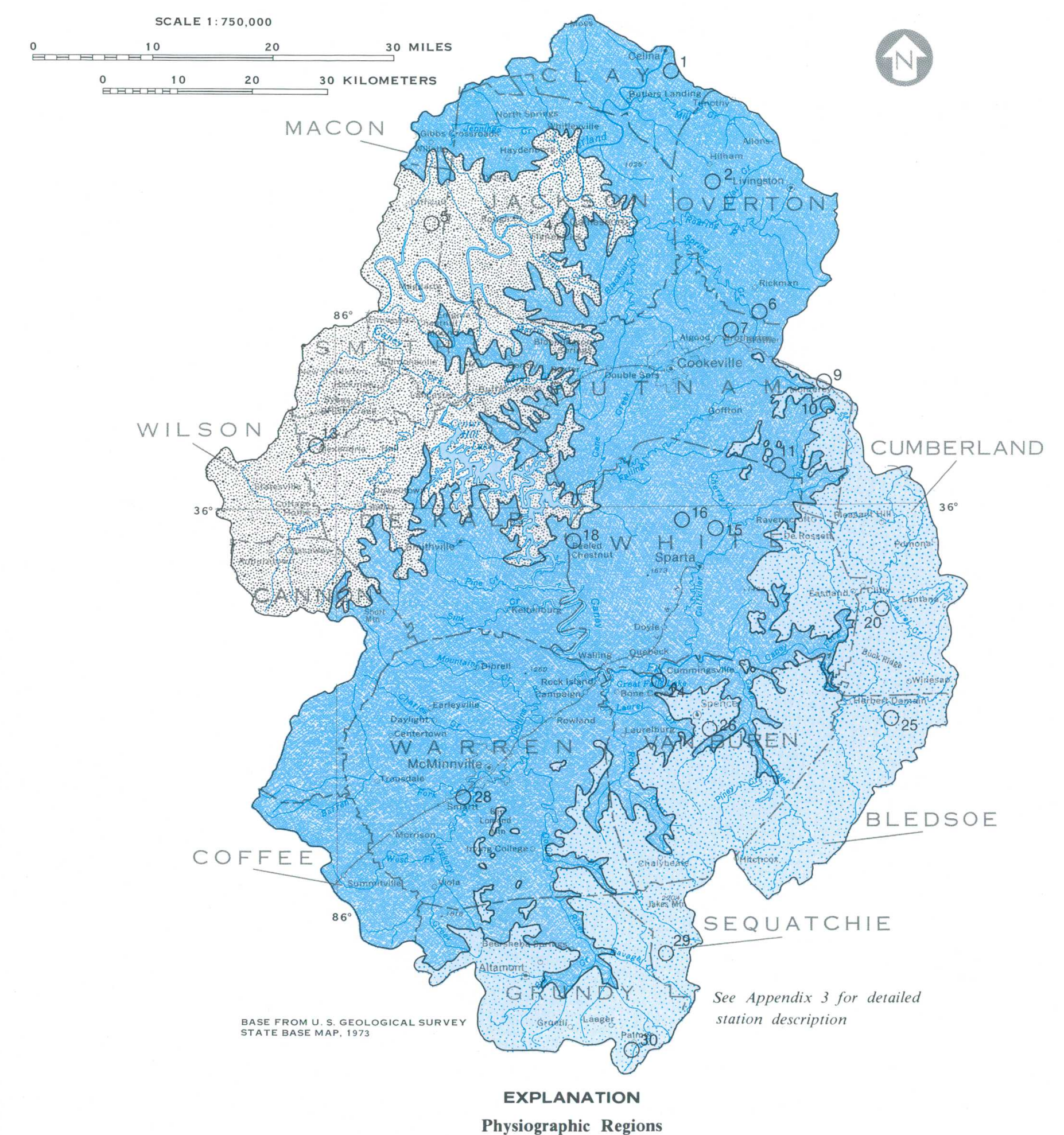

WELL NUMBER

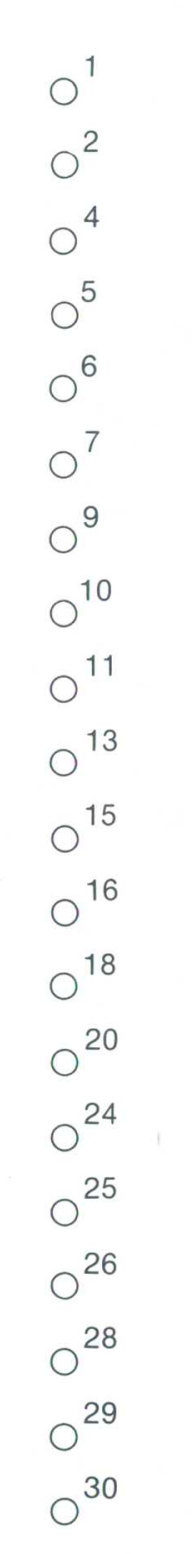

YEAR SAMPLED

1962
1977
1962
1952
1977
1962
1954
1977
1955
1954
1957
1955
1955
1954
1977
1954
1954
1954
1977
1954

SPECIFIC CONDUC1 at $25^{\circ} \mathrm{C}$ )

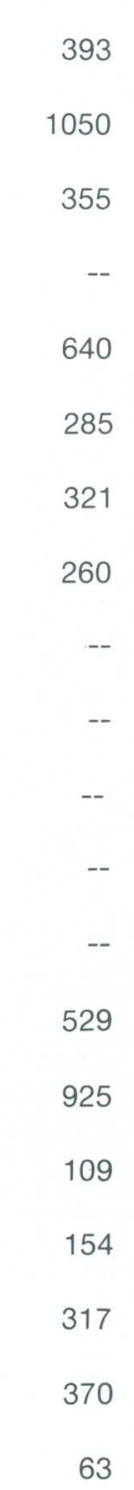

$\underset{\text { (units) }}{\mathrm{pH}}$
Cumberland Plateau
Central Basin
Highland Rim
$\mathrm{O}^{1} \quad$ Well and number 


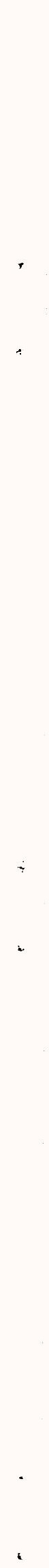




\title{
9.0 WATER-DATA SOURCES \\ 9.1 Introduction
}

\section{NAWDEX, WATSTORE, AND OWDC INFORMATION}

\author{
Water data are collected in coal areas by large number of \\ organizations in response to a wide variety of missions and needs.
}

Within the U.S. Geological Survey there are three activities that help to identify and improve access to the vast amount of existing water data. These activities are:

(1) The National Water Data Exchange (NAWDEX), which indexes the water data available from over 400 organizations and serves as a central focal point to help those in need of water data to determine what information is available.

(2) The National Water Data Storage and Retrieval System (WATSTORE), which serves as the central repository of water data collected by the U. S. Geological Survey and which contains large volumes of data on the quantity and quality of both surface and ground waters.

(3) The Office of Water Data Coordination (OWDC), which coordinates Federal water-data acquisition activities and maintains a "Catalog of Information on Water Data." To assist in identifying available water-data activities in coal provinces of the United States, special indexes to the Catalog are being printed and made available to the public.

A more detailed explanation of these three activities are given in sections 9.2, 9.3, and 9.4. 


\title{
9.0 WATER-DATA SOURCES (Continued) \\ 9.2 National Water Data Exchange--NAWDEX
}

\section{NAWDEX SIMPLIFIES ACCESS TO WATER DATA}

\author{
The National Water Data Exchange (NAWDEX) is a nationwide \\ program managed by the U.S. Geological Survey to \\ assist users of water data or water-related data \\ in identifying, locating, and acquiring needed data.
}

NAWDEX is a national confederation of wateroriented organizations working together to make their data more readily accessible and to facilitate a more efficient exchange of water data.

Services are available through a Program Office located at the U.S. Geological Survey's National Center in Reston, Virginia, and a nationwide network of Assistance Centers located in 45 states and Puerto Rico, which provide local and convenient access to NAWDEX facilities (fig. 9.2-1). A directory is available on request that provides names of organizations and persons to contact, addresses, telephone numbers, and office hours for each of these locations [Directory of Assistance Centers of the National Water Data Exchange (NAWDEX), U.S. Geological Survey Open-File Report 79-423 (revised)].

NAWDEX can assist any organization or individual in identifying and locating needed water data and referring the requester to the organization that retains the data required. To accomplish this service, NAWDEX maintains a computerized Master Water Data Index (fig. 9.2-2), which identifies sites for which water data are available, the type of data available for each site, and the organization retaining the data. A water Data Sources Directory (fig. 9.2-3) also is maintained that identifies organizations that are sources of water data and the locations within these organizations from which data may be obtained. In addition NAWDEX has direct access to some large water-data bases of its members and has reciprocal agreements for the exchange of services with others.

Charges for NAWDEX services are assessed at the option of the organization providing the requested data or data service. Search assistance services are provided free by NAWDEX to the greatest extent possible. Charges are assessed, however, for those requests requiring computer cost, extensive personnel time, duplicating services, or other costs encountered by NAWDEX in the course of providing services. In all cases, charges assessed by NAWDEX Assistance Centers will not exceed the direct costs incurred in responding to the data request. Estimates of cost are provided by NAWDEX upon request and in all cases where costs are anticipated to be substantial.

For additional information concerning the NAWDEX program or its services contact:

\author{
Program Office \\ National Water Data Exchange (NAWDEX) \\ U.S. Geological Survey \\ 421 National Center \\ 12201 Sunrise Valley Drive \\ Reston, VA 22092 \\ Telephone: (703) 860-6031 \\ FTS 928-6031
}

Hours: 7:45 - 4:15 Eastern Time

or

\author{
NAWDEX ASSISTANCE CENTER \\ TENNESSEE \\ U.S. Geological Survey \\ Water Resources Division \\ A413 Federal Building - U.S. Courthouse \\ Nashville, TN 37203 \\ Telephone: (615) 251-5424 \\ FTS 852-5424
}

Hours: 7:45 - 4:30 Central Time 


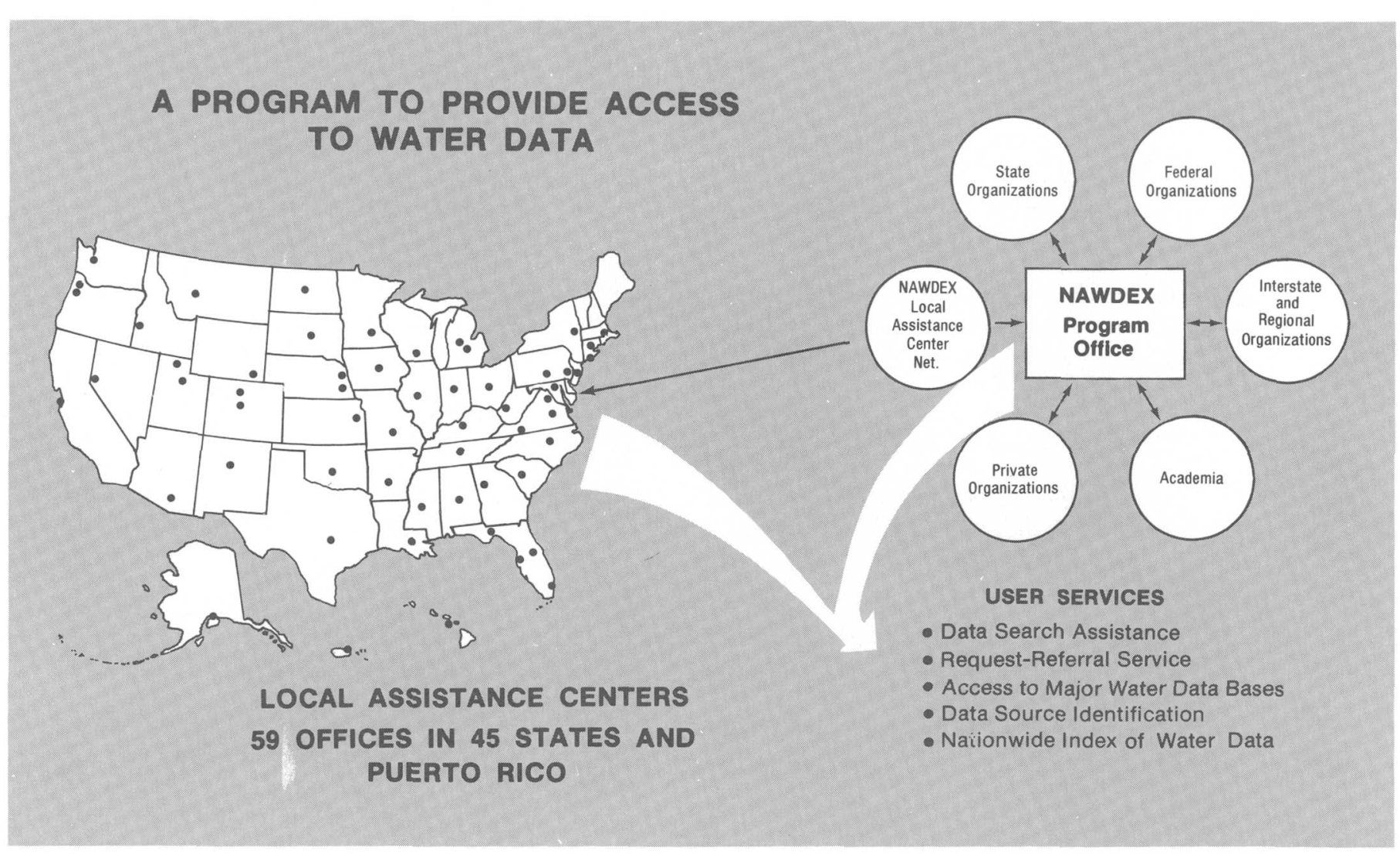

Figure 9.2-1 Access to water data
MASTER WATER DATA INDEX

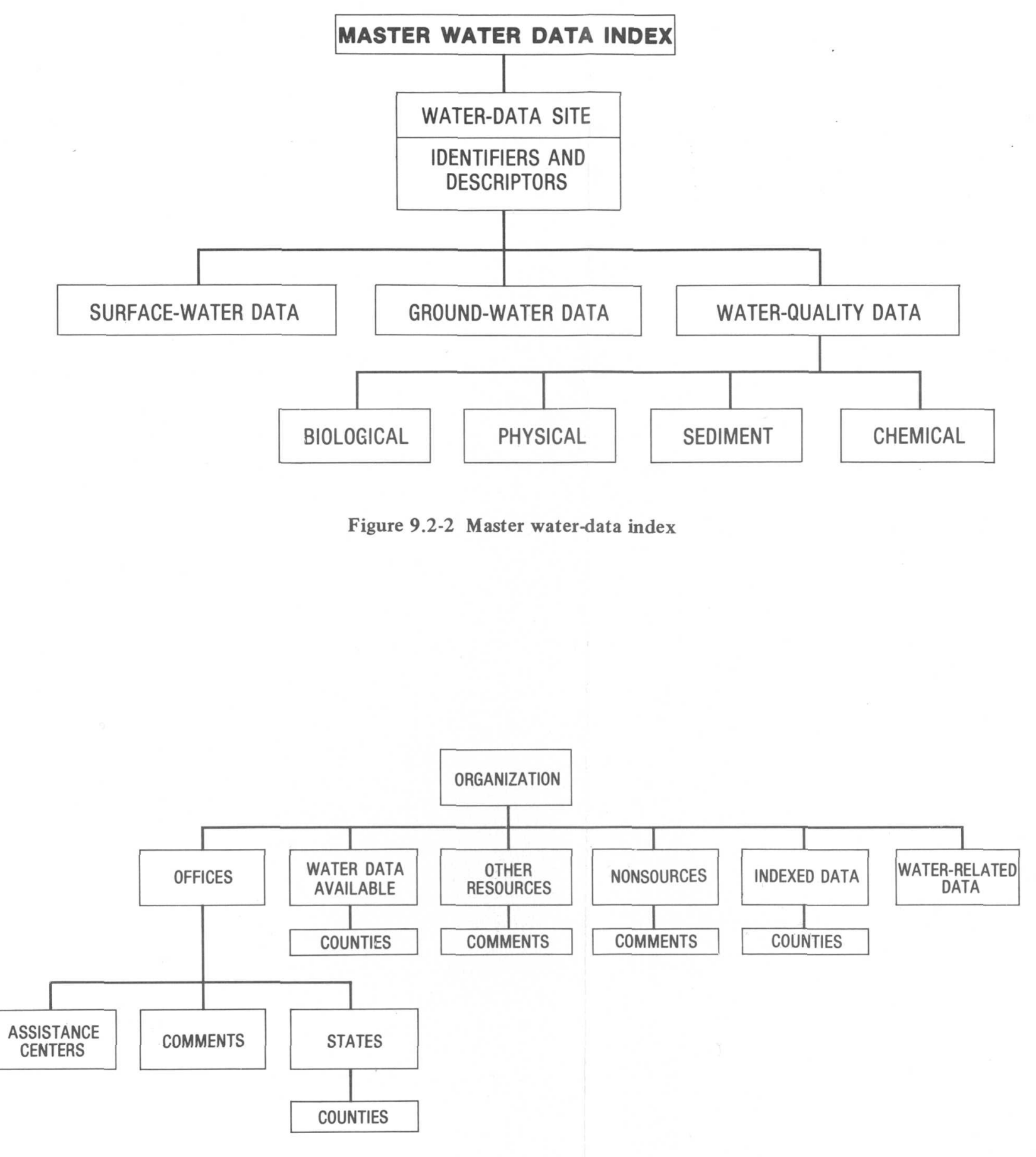

Figure 9.2-3 Water-data sources directory 


\title{
9.0 WATER-DATA SOURCES (Continued) 9.3 WATSTORE
}

\section{WATSTORE AUTOMATED DATA SYSTEM}

\author{
The National Water Data Storage and Retrieval System (WATSTORE) \\ of the U.S. Geological Survey provides computerized \\ procedures and techniques for processing water data \\ and provides effective and efficient management of \\ data-releasing activities.
}

The National Water Data Storage and Retrieval System (WATSTORE) was established in November 1971 to computerize the U.S. Geological Survey's existing water-data system and to provide for more effective and efficient management of its data-releasing activities. The system is operated and maintained on the central computer facilities of the Survey at its National Center in Reston, Virginia. Data may be obtained from WATSTORE through the Water Resources Division's 46 district offices. General inquiries about WATSTORE may be directed to:

\footnotetext{
Chief Hydrologist

U.S. Geological Survey

437 National Center

Reston, VA 22092
}

or

U.S. Geological Survey

Water Resources Division

A413 Federal Building - U.S. Courthouse

Nashville, TN 37203

The Geological Survey currently (1980) collects data at approximately 16,000 streamgaging stations, 1,000 lakes and reservoirs, 5,200 surface-water quality stations, 1,020 sediment stations, 30,000 waterlevel observation wells, and 12,500 ground-water quality wells. Each year many water-data collection sites are added and others are discontinued; thus, large amounts of diversified data, both current and historical, are amassed by the Survey's data-collection activities.

The WATSTORE system consists of several files in which data are grouped and stored by common characteristics and data-collection frequencies. The system is also designed to allow for the inclusion of additional data files as needed. Currently, files are maintained for the storage of: (1) surface-water, quality-of-water, and ground-water data measured on a daily or continuous basis; (2) annual peak values for streamflow stations; (3) chemical analyses for surface- and ground-water sites; (4) water parameters measured more frequently than daily; and (5) geologic and inventory data for ground-water sites. In addition, an index file of sites for which data are stored in the system is also maintained (fig. 9.3-1). A brief description of each file is as follows:

Station Header File: All sites for which data are stored in the Daily Values, Peak Flow, Water-Quality, and Unit Values files of WATSTORE are indexed in this file. It contains information pertinent to the identification, location, and physical description of nearly 220,000 sites.

Daily Values File: All water-data parameters measured or observed either on a daily or on a continuous basis and numerically reduced to daily values are stored in this file. Instantaneous measurements at fixed-time intervals, daily mean values, and statistics such as daily maximum and minimum values also may be stored. This file currently contains over 200 million daily values including data on streamflow, river stages, reservoir contents, water temperatures, specific-conductance, sediment concentrations, sediment discharges, and ground-water levels.

Peak Flow File: Annual maximum (peak) streamflow (discharge) and gage height (stage) values at surface-water sites comprise this file, which currently contains over 400,000 peak observations.

Water-Quality File: Results of over 1.4 million analyses of water samples that describe the chemical, physical, biological, and radiochemical characteristics of both surface and ground waters are contained in this file. These analyses contain data for 185 different constituents.

Unit Values File: Water parameters measured on a schedule more frequent than daily are stored in this 
file. Rainfall, stream discharge, and temperature data are examples of the types of data stored in the Unit Values File.

Ground-Water Site-Inventory File: This file is Wiscussed above, but it is cross-referenced to the tains inventory data about wells, springs, and other sources of ground water. The data included are site location and identification, geohydrologic characteristics, well-construction history, and one-time field measurements such as water temperature. The file is rently contains data for nearly 70,000 sites.

All data files of the WATSTORE system are maintained and managed on the central computer facilities of the Geological Survey at its National Center. However, data may be entered into or rethat are part of a nationwide telecommunication network.

Remote Job Entry Sites: Almost all of the Wate Resources Diviston's district offices are equipped with high-speed computer terminals for remote aclow each site to put data into or retrieve data from the system within several minutes to overnight, depending upon the priority placed on the request. The number of remote job entry sites is increased as the need arises.

Digital Transmission Sites: Digital recorders are used at many field locations to record values for temperature, turbidity, wind direction, and chlorides. Data are recorded on 16-channel paper tape, which is removed from the recorder and transmitted over telephone lines to the receiver at Reston, Virginia. The data are recorded on magnetic tape for use on the central computer. Extensive testing of sability for collecting real-time hydrologic data on a national scale. Battery-operated radios are used as the communication link to the satellite. About 200 data relay stations are being operated currently (1980).

Central Laboratory System: The Water Resources Division's two water-quality laboratories, analyze more than 150,000 water samples per yearThese laboratories are equipped to automatically perform.chemical analyses ranging from determinations of simple inorganic compounds, such as chlorides, to complex organic compounds, such as pesticides. As each analysis is completed, the results are verified by laboratory personnel and ransmitted via a computer stored in the Water-Quality File of WATSTOR

Water data are used in many ways by decisionmakers for the management, development, and monitoring of our water resources. In addition to its data processing, storage, and retrieval capabilities, WATSTORE can provide a variety of usefu products ranging from simple data tables to complex computer cost incurred in producing a desired product, is charged to the requester.

Computer-Printed Tables: Users most often request data from WATSTORE in the form of tables printed by the computer. These tables may contain the availability of data stored in the files. A variety of formats is available to display the many types of data.

Computer-Printed Graphs: Computer-printed graphs for the rapid analysis or display of data are a (histograms), line graphs, frequency distribution curves, X-Y point plots, site-location map plots, and other similar items by means of line printers.

Statistical Analyses: WATSTORE interfaces with a proprietary statistical package (SAS) to proanalyses, the analysis of variance, transformations, and correlations.

Digital Plotting: WATSTORE also makes use of software systems that prepare data for digital plotting on peripheral offline plotters available at the central computer site. Plots that can be obtained in$\mathrm{X}$-Y point plots, contour plots, and three-dimensional plots.

Data in Machine-Readable Form: Data stored in WATSTORE can be obtained in machine-readable form for use on other computers or for use as input available in the standard storage format of the WATSTORE system or in the form of punched cards or card images on magnetic tape.

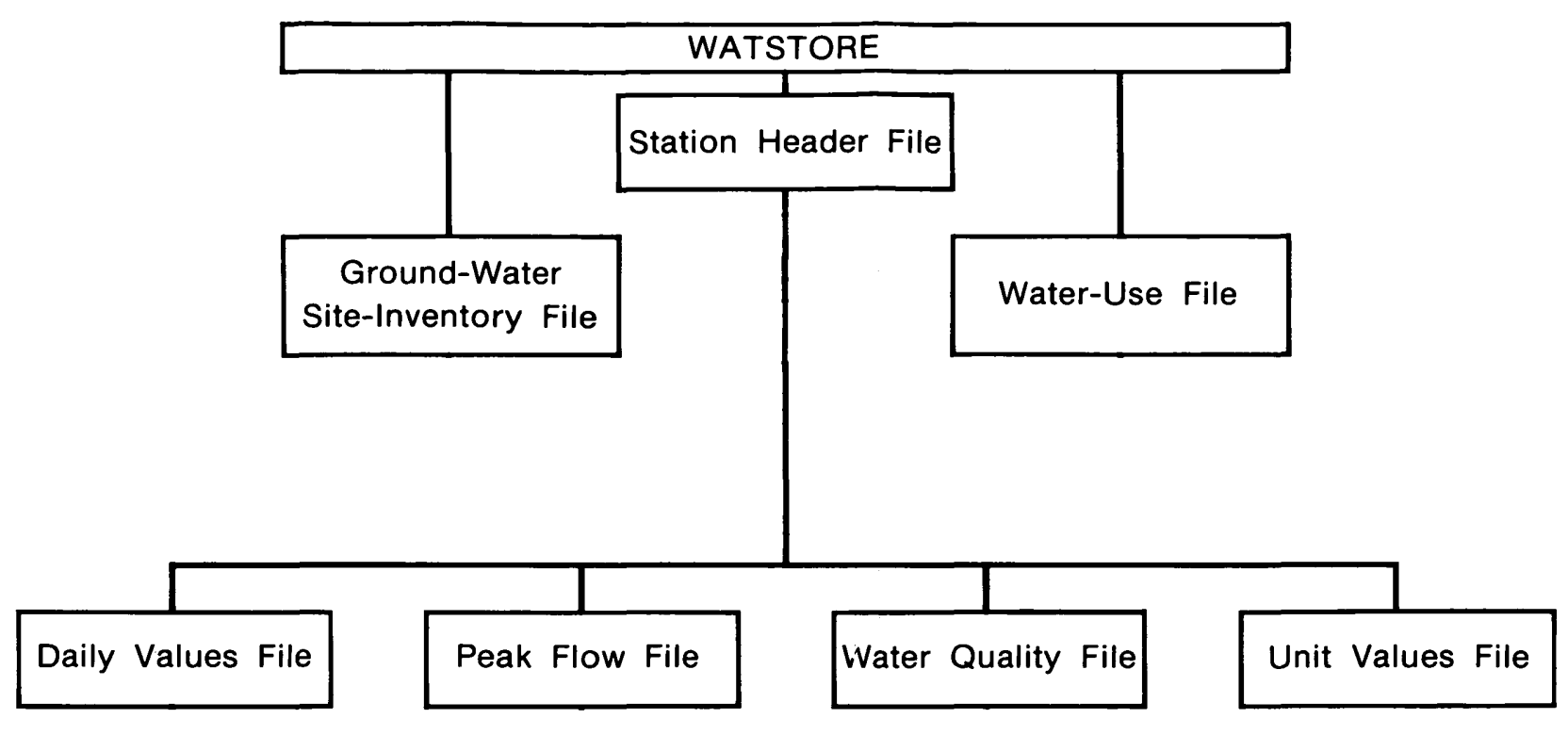

Figure 9:3-1 Files of stored data
9.0 WATER-DATA SOURCES (Continued) 9.3 WATSTORE 
9.0 WATER-DATA SOURCES (Continued)

9.4 Index to Water-Data Activities in Coal Provinces

\section{WATER DATA INDEXED FOR COAL PROVINCES}

\section{A special index, "Index to Water-Data Activities in Coal Provinces of the United States," has been published by the U.S. Geological Survey's Office of Water Data Coordination (OWDC).}

The "Index to Water-Data Activities in Coal Provinces of the United States" was prepared to assist those involved in developing, managing, and regulating the Nation's coal resources by providing information on the availability of water-resources data in the major coal provinces of the United States. It is derived from the "Catalog of Information on Water Data," which is a computerized information file about water-data acquisition activities in the United States, and its territories and possessions, with some international activities included.

This special index consists of five volumes (fig. 9.4-1): volume I, Eastern Coal province; volume II, Interior Coal province; volume III, Northern Great Plains and Rocky Mountain Coal provinces; volume IV, Gulf Coast Coal province; and volume V, Pacific Coast and Alaska Coal provinces. The information presented will aid the user in obtaining data for evaluating the effects of coal mining on water resources and in developing plans for meeting additional water-data needs. The report does not contain the actual data; rather, it provides information that will enable the user to determine if needed data are available.

Each volume of this special index consists of four parts: Part A, Streamflow and Stage Stations; Part B, Quality of Surface-Water Stations; Part C, Quality of Ground-Water Stations; and Part D, Areal Investigations and Miscellaneous Activities. Information given for each activity in Parts A-C includes: (1) the identification and location of the station, (2) the major types of data collected, (3) the frequency of data collection, (4) the form in which the data are stored, and (5) the agency or organization reporting the activity. Part D summarizes areal hydrologic investigations and water-data activities not included in the other parts of the index. The agencies that submitted the information, agency codes, and the number of activities reported by type are shown in a table.

Those who need additional information from the Catalog file or who need assistance in obtaining water data should contact the National Water Data Exchange (NAWDEX) (see section 9.2).

Further information on the index volumes and their availability may be obtained from:

\author{
U.S. Geological Survey \\ Water Resources Division \\ A413 Federal Building - U.S. Courthouse \\ Nashville, TN 37203
}

Telephone: (615) 251-5424

FTS $852-5424$

or

Office of Surface Mining

U.S. Department of the Interior

530 Gay St., Suite 500

Knoxville, TN 37902

Telephone: (615) 637-8060

FTS 852-0060 


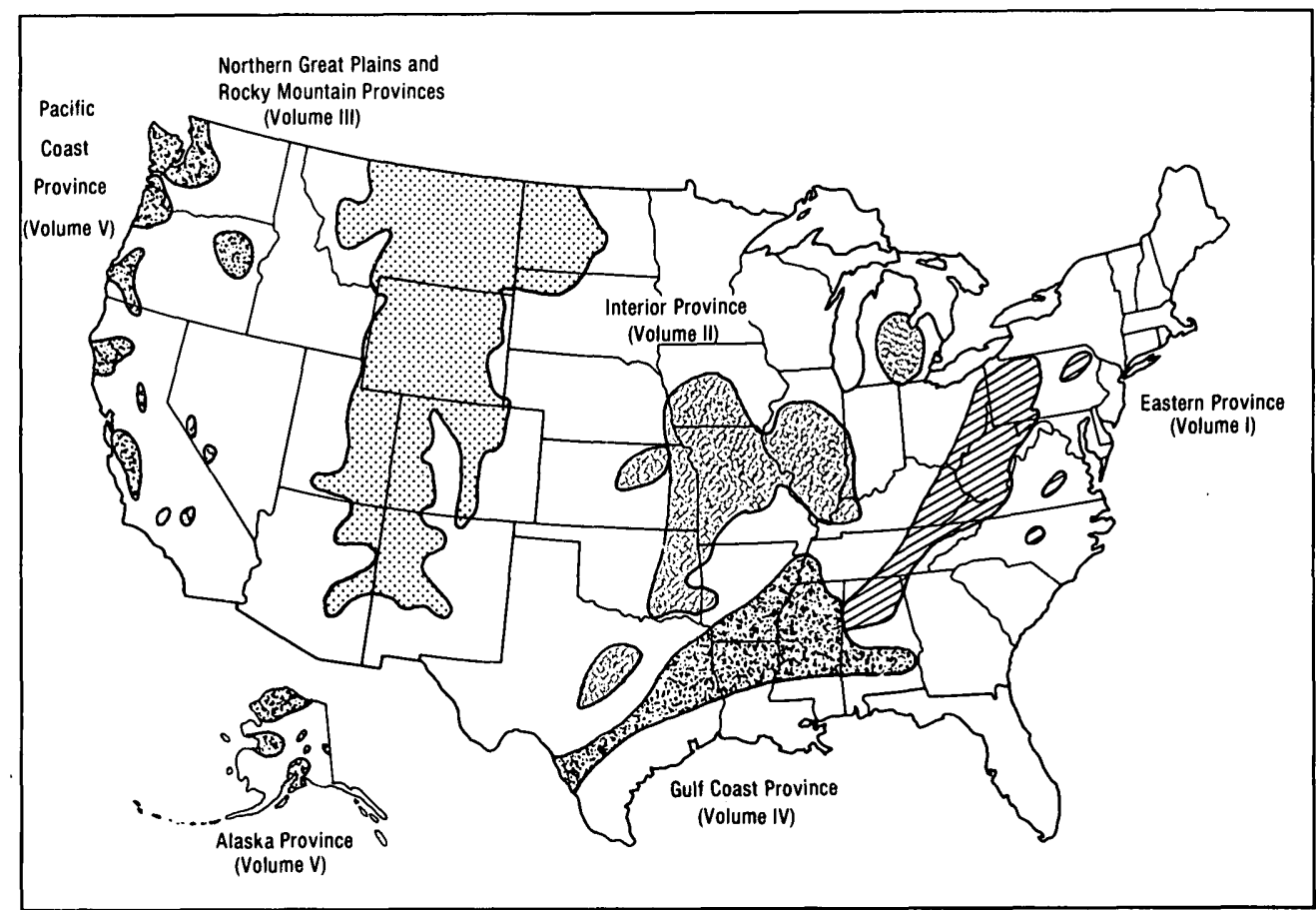

Figure 9.4-1 Index volumes and related provinces 


\subsection{SELECTED REFERENCES}

Crawford, N. C., 1979, The karst hydrogeology of the Cumberland Plateau of Tennessee, Part I: Subterranean stream invasion, conduit cavern development, and slope retreat in the Lost Creek Cove area, White County, Tennessee: Western Kentucky University, Dept. Geography and Geology, Cave and Karst Studies 1, Bowling Green, KY, 75 p.

Elder, J. A., and Springer, M. E., 1978, General soil map, Tennessee: U.S. Soil Conservation Service state soil map, scale 1:750,000.

Fenneman, N. M., 1938, Physiography of eastern United States: New York, McGraw-Hill, 714 p.

Gamble, C. R. and Lewis, J. G., 1977, Technique for estimating depth of 100-year floods in Tennessee: Nashville, Tennessee, U.S. Geological Survey Open-File Report 77-668, 18 p.

Gold, R. L., 1980, Low flow measurements of Tennessee streams: Tennessee Department of Conservation, Division of Water Resources, Water Resources Series No. 14, 362 p.

1981, Low-flow frequency and flow duration of Tennessee streams: Nashville, Tennessee, U.S. Geological Survey Open-File Report 78-807, 361 p.

Hardeman, W. D., 1966, Geologic map of Tennessee, east-central sheet: Tennessee Division of Geology state map, scale 1:250,000.

1966, Geologic map of Tennessee, west-central sheet: Tennessee Division of Geology state map, scale 1:250,000.

Hollyday, E. F., and Hansen, G. R., Improving estimates of streamflow characteristics in the Cumberland Plateau of Tennessee by using digital land-cover data from the Landsat satellite: U.S. Geological Survey Open-File Report, in review, $62 \mathrm{p}$.

Longwell, T. J., Parks, W. L., and Springer, M. E., 1963, Moisture characteristics of Tennessee soils: University of Tennessee Agricultural Experiment Station Bulletin 367, Knoxville, Tennessee, 46 p.

May, V. J., Wood, G. H., and Rima, D. R., 1970, A proposed streamflow-data program for Tennessee: U.S. Geological Survey Open-File Report, $55 \mathrm{p}$.

Milici, R. C., 1969, Geologic map of the Spencer quadrangle, Tennessee: Tennessee Division of Geology Geologic Map 103-NW, scale 1:24,000.

Milici, R. C. and others, 1979, The Mississippian and Pennsylvanian (Carboniferous) Systems in the United States - Tennessee: U.S. Geological Survey Professional Paper 1110-G, 38 p.

Miller, R. A., 1974, The geologic history of Tennes- see: Tennessee Division of Geology Bulletin 74, $63 \mathrm{p}$.

Moore, G. K., and Wilson, J. M., 1972, Water resources of the Center Hill Lake region, Tennessee: Tennessee Division of Water Resources, Water Resources Series No. 9, 77 p.

Newcome, Roy, Jr., and Smith, Ollie, Jr., 1958, Ground-water resources of the Cumberland Plateau in Tennessee-a reconnaissance report: Tennessee Division of Water Resources publication, $72 \mathrm{p}$.

Randolph, W. J., and Gamble, C. R., 1976, Technique for estimating magnitude and frequency of floods in Tennessee: Tennessee Department of Transportation, $52 \mathrm{p}$.

Rorabaugh, M. I., 1960, Use of water levels in estimating aquifer constants in a finite aquifer: International Association of Scientific Hydrology publication 52, p. 314-323.

Surface Mining Control and Reclamation Act of 1977 - Public Law 95-87, 1977.

Tennessee Department of Public Health, 1978, Statewide 208 water quality management plan: Division of Water Quality Control, several vols., unnumbered.

U.S. Department of Commerce, 1960, Climates of the states, Tennessee: U.S. Weather Bureau, Climatography of the U.S., No. 60-40, 16 p.

1961, Rainfall frequency atlas of the United States: Weather Bureau, Technical Paper No. 40,115 p.

U.S. Environmental Protection Agency, 1976, National interim primary drinking water regulations: Environmental Protection Agency Report 570/9 - 76-003, 159 p.

U.S. Geological Survey, 1974, Hydrologic unit map 1974 State of Tennessee: U.S. Geological Survey, scale $1: 500,000$.

1979 , Index to water-data activities in coal provinces of the United States: Office of Water Data Coordination (OWDC), vol. 1, Eastern Province.

1965-79, Water resources data for Tennessee: U.S. Geological Survey Water Data Report, issued annually.

1980, Directory of assistance centers of the National Water Data Exchange (NAWDEX): U.S. Geological Survey Open-File Report 80-1193, $10 \mathrm{p}$.

Wark, J. W., 1965, in Schneider, W. J., and others, Water Resources of the Appalachian Region, Pennsylvania to Alabama: U.S. Geological Survey Hydrologic Atlas HA-198, 11 sheets. 
Wilson, J. M., 1965, Ground-water resources and geology of Cumberland County, Tennessee: Tennessee Division of Water Resources, Water Resources Series 6, $56 \mathrm{p}$.

Zurawski, Ann, 1978, Summary appraisals of the
Nation's ground-water resources-Tennessee region: U.S. Geological Survey Professional Paper $813-\mathrm{L}, 35 \mathrm{p}$. 
Appendix 1 Stream use classification Tennessee streams

Definition of Classification Codes

$\begin{array}{llll}\text { DOM } & \text { Domestic water supply } & \text { REC } & \text { Recreation } \\ \text { IND } & \text { Industrial water supply } & \text { IRR } & \text { Irrigation } \\ \text { FISH } & \text { Fish and aquatic life } & \text { LW\&W } & \text { Livestock watering and wildife }\end{array}$

CLASSIFICATION

STREAM

Cumberland River Caney Fork River Caney Fork River Mulherrin Creek Hickman Creek Hickman Creek Hickman Creek Smith Fork Creek Dry Creek

Jones Fork

Mine Lick Creek

Mine Lick Creek

Mine Lick Creek

Mine Lick Creek

Falling Water River

Falling Water River

Falling Water River Cane Creek Pigeon Roost Creek Pigeon Roost Creek

Fall Creek

Fall Creek

Pine Creek Turner Branch

Sink. Creek

Collins River Mountain Creek

Charles Creek

Barren Fork River

Barren Fork River Barren Fork River Hickory Creek

W. F. Hickory C. Keel Branch Keel Branch

Hills Creek

Collins River

Big Creek

Big Creek

Big Creek

Big Creek

Big Creek

Caney Fork River

Rocky River

Calfkiller River

Calfkiller River

Calfkiller River

Calfkiller River Town Creek

Cane Creek

Falls Creek

Bee Creek

Bee Creek

Bee Creek

Wilkerson Creek

Wilkerson Creek

Frey Branch

Frey Branch

Roaring River

Spring Creek

Bear Creek

Bear Creek

Bear Creek

Carr Creek

Carr Creek

Town Creek

Town Creek

Town Creek
DESCRI PTION

(miles above mouth)

Mile 309.2 to 385.5 (Ky.-Tenn. Line)

Mile 0.0 to 25.4

Mile 25.4 to origin

Mile 0.0 to origin

Mile 0.0 to 10.7

Mile 10.7 to 13.7

Mile 13.7 to origin

Mile 0.0 to origin

Mile 0.0 to origin

Mile 0.0 to origin

Mile 0.0 to 5.0

Mile 5.0 to 10.5

Mile 10.5 to 13.5

Mile 13.5 to origin

Mile 0.0 to 39.0

Mile 39.0 to 42.0

Mile 42.0 to origin

Mile 0.0 to origin

Mile 0.0 to 2.0

Mile 2.0 to origin

Mile 0.0 to 3.2

Mile 3.2 to origin

Mile 0.0 to origin

Mile 0.0 to origin

Mile 0.0 to origin

Mile 0.0 to origin

Mile 0.0 to origin

Mile 0.0 to origin

Mile 0.0 to 1.5

Mile 1.5 to 4.5

Mile 4.5 to origin

Mile 0.0 to origin

Mile 0.0 to origin

Mile 0.0 to 1.3

Mile 1.3 to origin

Mile 0.0 to origin

Mile 43.0 to 49.0

Mile 0.0 to 6.0

Mile 6.0 to 6.7

Mile 6.7 to 10.0

Mile 10.0 to 10.6

Mile 10.6 to origin

Mile 92.2 to origin

Mile 0.0 to origin

Mile 0.0 to 6.0

Mile 6.0 to 11.1

Mile 11.1 to 14.1

Mile 14.1 to origin

Mile 0.0 to origin

Mile 0.0 to origin

Mile 0.0 to origin

Mile 0.0 to 4.3

Mile 4.3 to 7.3

Mile 7.3 to origin

Mile 0.0 to 2.6

Mile 2.6 to origin

Mile 0.0 to 0.2

Mile 0.2 to origin

Mile 0.0 to origin

Mile 0.0 to origin

Mile 0.0 to 4.6

Mile 4.6 to 6.1

Mile 6.1 to origin

Mile 0.0 to 5.0

Mile 5.0 to origin

Mile 0.0 to 2.0

Mile 2.0 to 3.5

Mile 3.5 to origin

$\underline{\text { DOM IND }} \underline{\text { FISH }}$ REC IRR LW\&W NAV




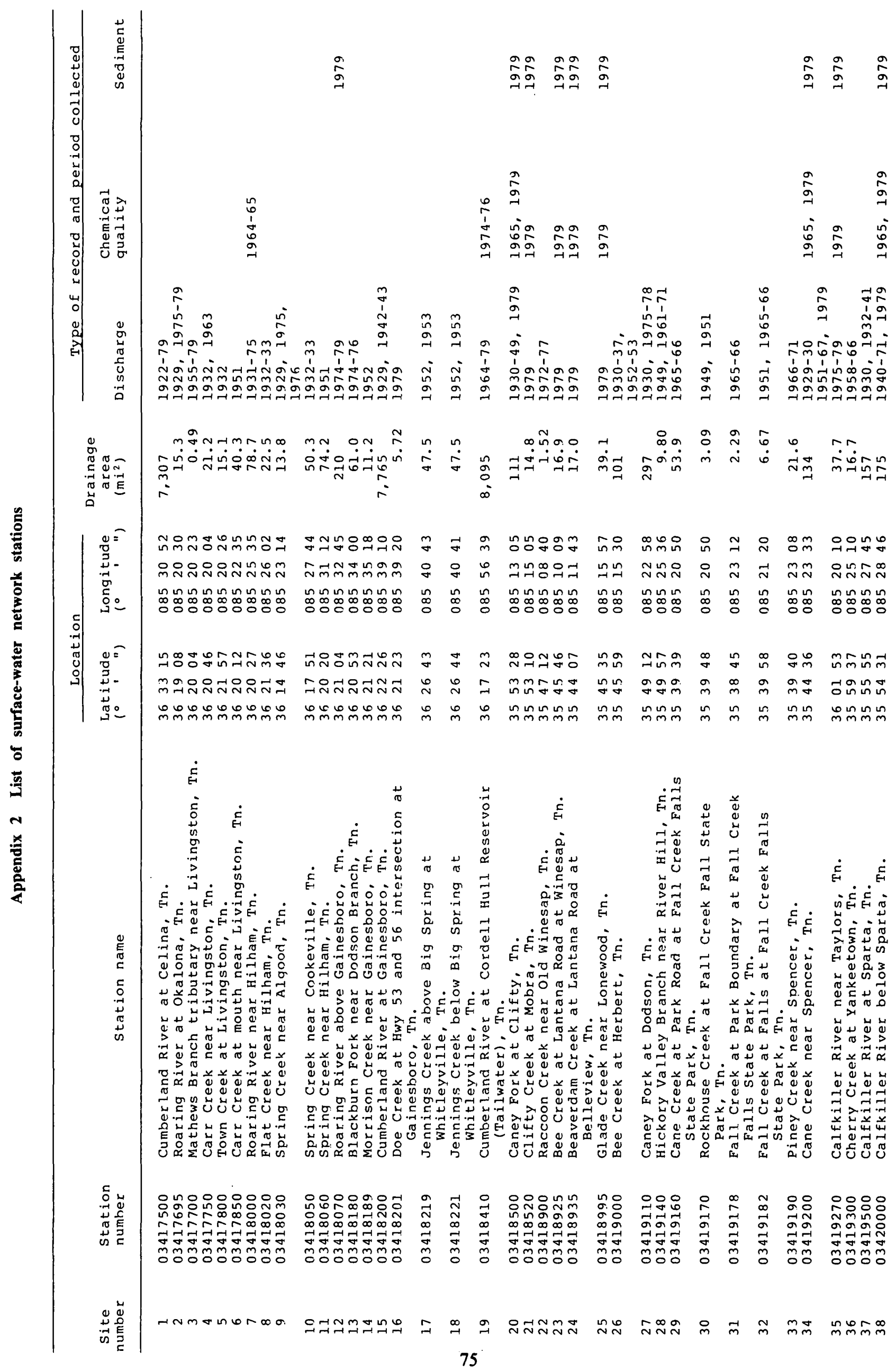




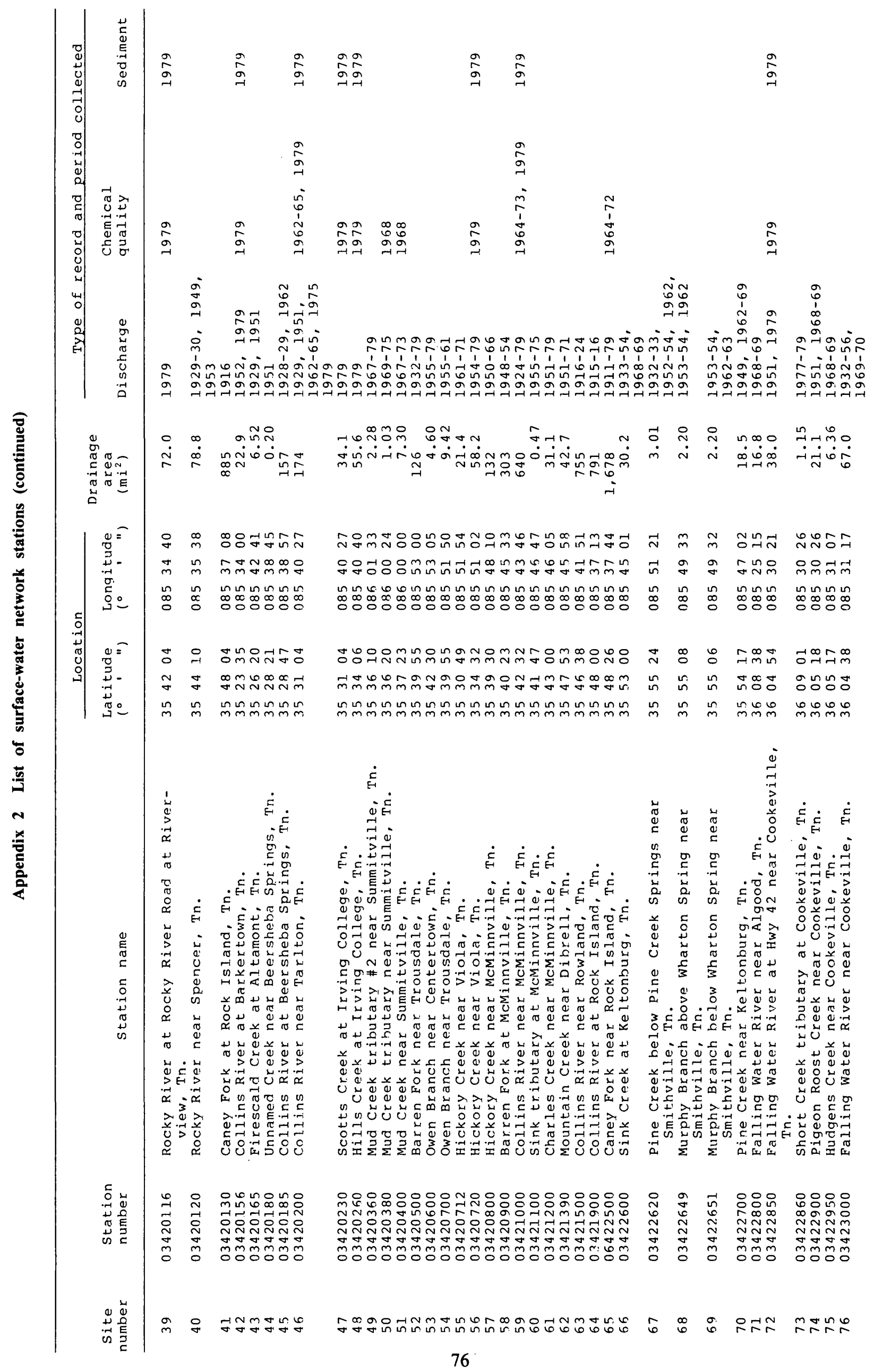




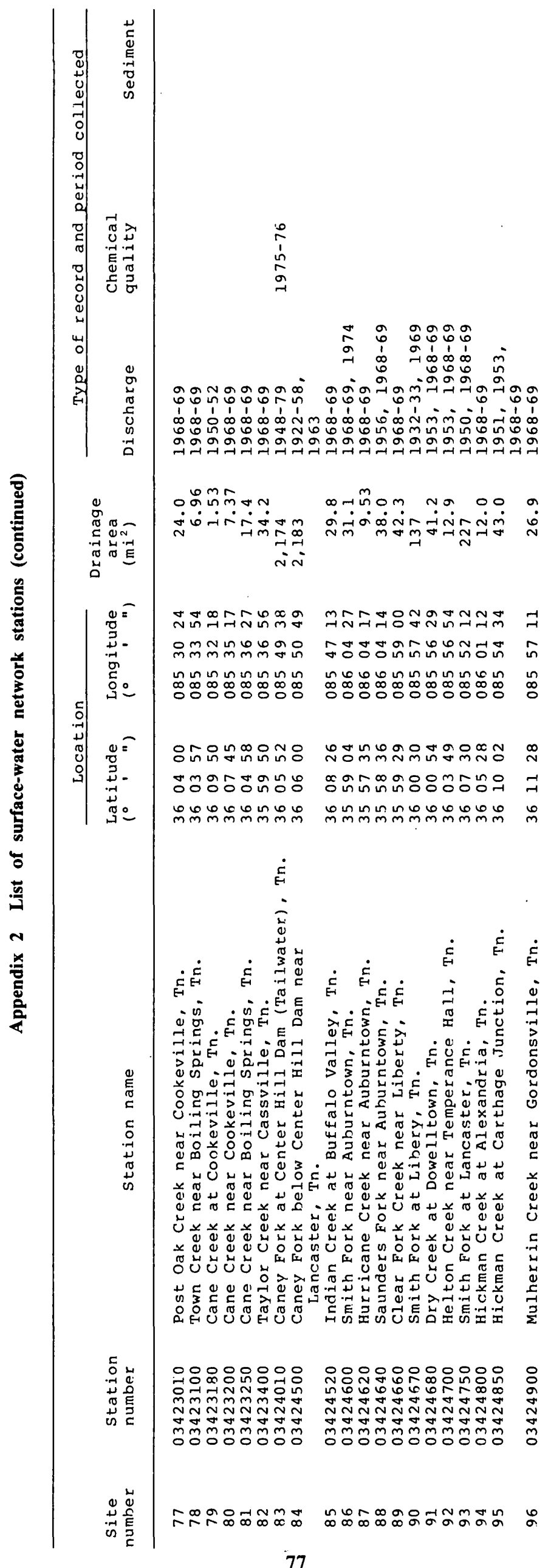




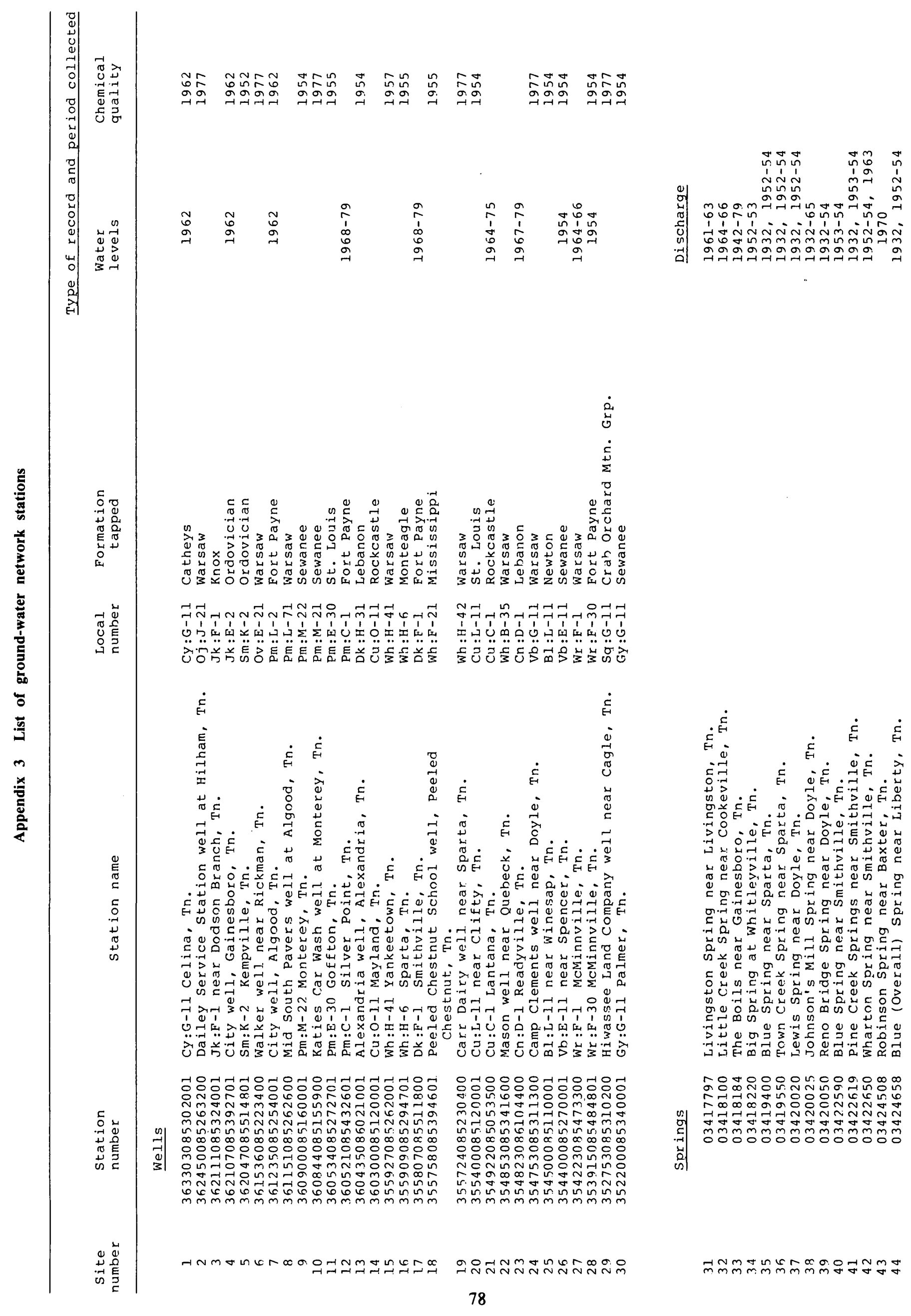


1

$?$ 
